\title{
O sintagma nominal do caboverdiano: uma investigação semântica
}

— versão corrigida —

WÂnia Miranda Araújo da Silva 


\section{O sintagma nominal do caboverdiano: uma investigação semântica}

— versão corrigida —

Wânia Miranda Araújo da Silva

Dissertação de Mestrado apresentada ao Programa de Pós-Graduação em Semiótica e Linguística Geral do Departamento de Linguística da Faculdade de Filosofia, Departamento de da Universidade de São Paulo para a obtenÇÃo do título de Mestre em Linguística.

Orientador: Prof. Dr. Marcos Lopes 


\section{Agradeço...}

Acima de tudo a Deus, por ter iluminado meus caminhos e a minha mente.

Ao Marcos Lopes, por ter sido um excelente orientador. Pela paciência, dedicação e acima de tudo por acreditar nesse projeto e em mim.

Ao Departamento de Linguística pelo financiamento da Viagem de Campo.

À CNPq pelo auxílio financeiro.

Aos professores do Departamento de Linguística que contribuíram para a minha formação.

À Prof ${ }^{a}$ Margarida Petter, um exemplo de pessoa e pesquisadora, sempre tão atenciosa e disposta a me ajudar.

À Prof ${ }^{a}$ Márcia Oliveira, que me iniciou nas pesquisas com o caboverdiano e que sempre me apoiou em tudo, mesmo depois de não ser mais minha orientadora.

À Prof ${ }^{a}$ Evani Viotti, por seus valorosos conselhos em cada uma das etapas desse mestrado.

À Prof ${ }^{a}$ Leila Hernandez, pelo seu maravilhoso curso de História da África e pelo seu carinho e apoio.

À Prof ${ }^{a}$ Simone Caputo Gomes, meu exemplo, por ter me acolhido em todos os eventos sobre Cabo Verde desde o início de meus estudos sobre o tema, por ter me ensinado a olhar outros aspectos, não só os linguísticos e principalmente, por ter me ajudado com a viagem de campo, realizando contatos e me incentivando sempre.

À Prof ${ }^{a}$ Ulisdete Rodrigues, da Universidade de Brasilia, por ter respondido a todas as minhas dúvidas e por ter sido tão generosa nos conselhos sobre a viagem de campo.

Aos funcionários do Departamento de Linguística, Érica, Ben-Hur e Robson.

Ao Paulo Cezar pela revisão do texto.

Ao Eduardo, pela companhia sempre constante em todos os momentos da minha vida acadêmica e por ter ultrapassado os muros da Academia tornando-se já um membro da família.

À Paula e Vanessa, as melhores amigas que a academia poderia ter me dado. Cada uma contribuiu, a seu modo, para que a vida acadêmica se tornasse melhor e mais prazerosa.

A tantos outros que tornaram esse caminho muito mais agradável, em especial ao Everton, Roberlei, Fernanda, Luciana, Ana Paula Quadros, Renata, Wallace, Manuelle, Shirley, Maria e tantos outros.

Ao Ricardo Jorge, por ter me ajudado com os dados do caboverdiano, esclarecendo minhas dúvidas. 
Ao Francisco, por sempre me ajudar em relação aos dados, esclarecer minhas dúvidas e sobretudo pela paciência e por ser sempre tão prestativo.

\section{Em Cabo Verde...}

Em primeiro lugar à Gabriela, prima de Francisco, por ter me acolhido em sua casa sem antes me conhecer. Por ter me oferecido não só abrigo, mas amizade. Obrigada pela preocupação, pelos conselhos, pelas conversas e sobretudo pelo exemplo de mulher e ser humano que levarei para sempre comigo.

Ao Júnior e Valdir, filhos de Gabriela, pelo acolhimento e cuidado.

Ao Prof. Dr. Manuel Veiga, por ter me recebido e ter me dado conselhos tão preciosos, além de ter me presenteado com seu livro Odju d’Águ.

Ao Prof. Natal, pela generosidade ao ceder tantos materiais, muitos deles raros, sobre o caboverdiano.

À Prof ${ }^{a}$ Maria de Fátima, por ter me acolhido e por ter sido tão gentil.

Ao Prof. Carlos, pela ajuda e por ter me acompanhado, juntamente com seu sobrinho, em uma das gravações.

Ao Francisco da Cidade Velha, não tenho palavras para agradecer a generosidade, mesmo depois de minha volta ao Brasil.

Em especial ao Prof. Luís Rodrigues, por ter me recebido sem reservas e ter me ajudado de uma forma tão generosa. Agradeço por ter solicitado a ajuda de seus alunos, por ter me acompanhado em algumas gravações, pelas caronas, pelos cafés e por ter me ajudado mesmo depois de minha volta ao Brasil.

Ao Otílio, Evandro e Necildo por terem se disponibilizado a servirem de intérpretes nas entrevistas e por terem realizado contato com os informantes, além de ter aberto as portas de suas casas para mim.

Ao Sr. Felisberto e ao João dos Santos por terem me ajudado a contactar informantes.

A todos os meus informantes, sem exceção, pela lição de vida e pela generosidade com que me acolheram. Ao sr. Chun, por ter me presenteado com os poucos ovos de galinha caipira que tinha e por ter me ensinado que "enquanto há vida, há lida." Ao sr. Francisco, por tantas histórias e por ter me ensinado a cheirar kankan (tabaco). Ao Francisco da Cidade Velha, que apesar de não ter sido meu informante, me ajudou imensamente e me apresentou o grógu direto do alambique e a tantos outros.

À Vânia, que não fez parte da pesquisa, mas que me ajudou muito com a companhia e conversas, mesmo que poucas, aliviando um pouco o peso 
de estar sozinha.

A minha família...

Aos meus pais, por terem me incentivado desde o início e por terem apoiado todas as minhas decisões em relação à vida acadêmica.

Ao Yuri, meu filho querido, a criança (ou adolescente) mais carinhoso e compreensível que existe no mundo.

Aos meus irmãos, Wanny, Wellington e, é claro, Flávia, pela paciência e compreensão de que nem sempre eu podia estar presente.

Ao Saulo, meu companheiro, por ter me apoiado nessa jornada e por ter trazido mais alegria e amor a minha vida.

Ao Totó... 
Descobri como é bom chegar quando se tem paciência. E para se chegar, onde quer que seja, aprendi que não é preciso dominar a força, mas a razão. É preciso, antes de mais nada, querer.

- Amyr Klink

Para compreender as línguas bantas [e africanas em geral], seria necessário que nos abstraíssemos da maior parte das nossas noções gramaticais europeias.

- Henri Junod

Se em tudo o mais forem idênticas as várias explicações de um fenômeno, a mais simples é a melhor.

- William de Ockham 


\section{Resumo}

A presente dissertação realiza uma investigação semântica do sintagma nominal (NP) do caboverdiano, língua falada no arquipélago de Cabo Verde, localizado na costa ocidental africana. As análises concentram-se na variedade de Santiago, ilha em que está localizada a capital do país, a cidade de Praia.

Os nomes no caboverdiano, em geral, não são acompanhados de determinante e podem ser interpretados tanto como definidos quanto indefinidos. A utilização de un / uns está, em geral, associada a introdução de novos referentes, seu uso, contudo, não é frequente. Existe, ainda, a partícula kel/kes que parece veicular, entre outras coisas, definitude. Tal emprego, todavia, tampouco se dá frequentemente.

O estatuto de $\mathrm{kel}$, em caboverdiano, causa algumas divergências entre os pesquisadores da língua. Alguns autores advogam que ele desempenha, por vezes, o papel de artigo definido (ver, entre outros, (Alexandre and Soares, 2004), (Baptista, 2007), (Quint, 2000)). Discutiremos alguns dos trabalhos que versam sobre o sintagma nominal em caboverdiano, apresentando argumentos que corroboram ou não essa hipótese.

A bem da verdade, a maioria das descrições sobre o caboverdiano não manifesta acordo quanto à existência ou não de artigo definido nessa língua. Os que afirmam sua existência parecem, muitas vezes, apresentar análises da língua centradas na descrição e análise do português, principalmente do português europeu. Diante dessa perspectiva, diversos fenômenos idiossincráticos do caboverdiano podem passar despercebidos, como no caso de uma possível contribuição ilocucional do operador uma, outro modificador do sintagma nominal.

Este trabalho procura realizar uma análise do caboverdiano centrada nos fatos da própria língua, investigando as diferentes estratégias de interpretação dos nomes, bem como o papel dos elementos que compõem o sintagma nominal.

Palavras-chave: semântica, sintagma nominal, caboverdiano, definitude. 


\begin{abstract}
This dissertation conducts an investigation of the semantic of the noun phrase (NP) Cape Verdean language, spoken in the Cape Verde, archipelago located on the West African coast. The analysis focuses on the Santiago variety.

The nouns in the Cape Verdean are generally determinerless and can be interpreted both as definite and indefinite. The introduction of new referents is generally associated with the use of un/uns, it's use however is not frequent. There are also the particle kel/kes it seems vehicle, among other things, definiteness. Such employement, however, nor is often gives.

The status of kel in Cape Verdean, cause some disagreement among of the language researchers. Some scholars advocate that kel may assume, sometimes, the role of a definite article (see among others (Alexandre and Soares, 2004), (Baptista, 2007), (Quint, 2000)). I will discuss several works which deal with noun phrase in Cape Verdean, revealing arguments which confirm whether or not this hypothesis.

In fact, most of the Cape Verdean descriptions not show agreement on the definite article presence or absence in that language. Those who claim its existence often seem to present analysis of the Cape Verdean centered on the description and analysis of the Portuguese, especially European Portuguese. With that prospect, severals idiosyncratic phenomena of the Cape Verde may go unnotice, as in the case of a possible illocutionary contribution of the uma operator, another noun phrase modifier.

This work attempt examine of the an Cape Verdean analyse focused on the language facts theirselves, investigating different strategies for nouns interpretation, as well as the elements role on the noun phrase.
\end{abstract}

Keywords: semantics, noun phrase, Cape Verdean, definiteness. 


\section{Lista de abreviações}

$\begin{array}{ll}\text { 1SG/2SG/3SG } & 1^{a} / 2^{a} / 3^{a} \text { pessoa do singular } \\ \text { 1PL/2PL/3PL } & 1^{a} / 2^{a} / 3^{a} \text { pessoa do plural } \\ \text { CAIXA ALTA } & \text { acento fonológico } \\ \text { ADV } & \text { advérbio } \\ \text { COMP } & \text { complementizador } \\ \text { CONJ } & \text { conjunção } \\ \text { DEM } & \text { demonstrativo } \\ \text { DET } & \text { determinante } \\ \text { F } & \text { feminino } \\ \text { GRAU } & \text { flexão de grau } \\ \text { HAB } & \text { aspecto habitual } \\ \text { IMPF } & \text { imperfeito } \\ \text { Int } & \text { intensificador } \\ \text { M } & \text { masculino } \\ \text { NEG } & \text { partícula de negação } \\ \text { OBJ } & \text { objeto } \\ \text { OBL } & \text { oblíquo } \\ \text { PFV } & \text { perfectivo } \\ \text { PON } & \text { aspecto pontual } \\ \text { POSS } & \text { possessivo } \\ \text { POT } & \text { aspecto potencial } \\ \text { PREP } & \text { preposição } \\ \text { PROG } & \text { aspecto progressivo } \\ \text { PST } & \text { passado } \\ \text { PRON } & \text { pronome } \\ \text { QP } & \text { sintagma quantificador } \\ \text { REFL } & \text { reflexivo } \\ \text { SING } & \text { singularizador } \\ \text { T } & \text { pronome tônico } \\ & \end{array}$


$\begin{array}{ll}\text { Abstract } & \text { ix }\end{array}$

Lista de abreviações $\quad x$

1 Apresentação 1

2 Metodologia 3

2.1 Metodologia e Trabalho de Campo ... . . . . . . . 3

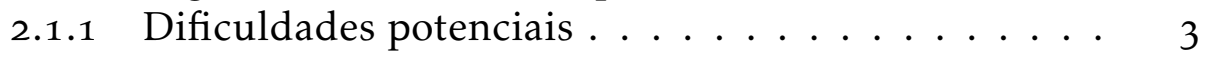

2.1.2 Coleta e transcrição dos dados . . . . . . . . . 4

2.2 Sobre o corpus . . . . . . . . . . . . . . 5

2.3 Um detalhe ortográfico . . . . . . . . . . . 8

3 A terra e a língua 9

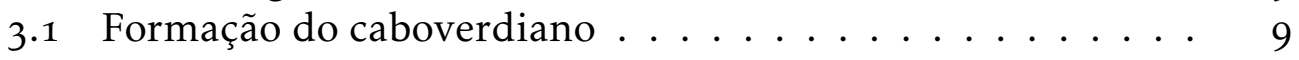

3.1 .1 Aspectos geográficos ...................... 9

3.1 .2 Aspectos sócio-históricos ............ 10

3.2 Características do caboverdiano . . . . . . . . 12

3.2.1 Língua materna versus língua oficial . . . . . . 12

3.2.2 Caraterísticas morfossintáticas da língua ...... 13

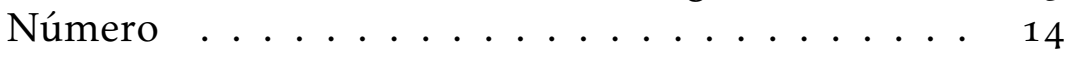

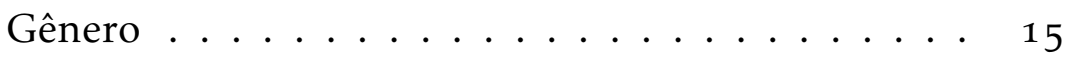

Pronomes Pessoais . . . . . . . . . . . . 15

Domínio Verbal . . . . . . . . . . . 16 
4 Línguas Crioulas 20

4.1 Introdução . . . . . . . . . . . . . . 20

4.2 Sobre o surgimento das línguas crioulas ......... 21

4.2.1 Teorias que tomam como foco o input europeu . . . 22

Teorias monogenéticas . . . . . . . . . 22

Foreigner talk e baby talk . . . . . . . . . . 23

Aprendizagem imperfeita de segunda língua . . . . 24

4.2.2 Teorias que focam o input não europeu . . . . . . . . 24

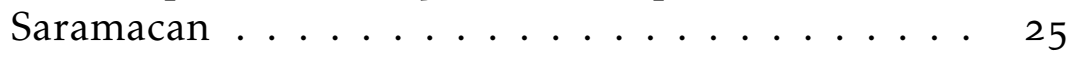

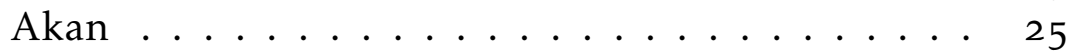

4.2 .3 Hipóteses gradualistas ............. . . 26

4.2.4 Abordagens universalistas ........... 27

4.3 O método histórico comparativo . . . . . . . . . 28

4.4 Crioulização como a propriação linguística . . . . . . . . . . 29

4.5 Evolução das línguas como especiação . . . . . . . . . . 32

4.5.1 Evolução de línguas e línguas crioulas . . . . . . 35

4.6 O estatuto das línguas crioulas . . . . . . . . . . . 36

4.7 Considerações . . . . . . . . . . . . . . 38

5 O sintagma nominal do caboverdiano 39

5.1 Introdução . . . . . . . . . . . . . . 39

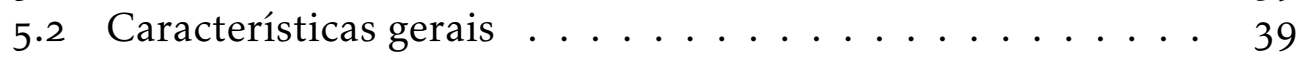

5.3 Os nomes nus no caboverdiano ........... 42

5.3.1 Sobre os nomes nus: discussão teórica . . . . . . 43

$5 \cdot 3.2$ A noção de pressuposição . . . . . . . . . 46

$5 \cdot 3 \cdot 3$ Leitura genérica no caboverdiano . . . . . . . 47

$5 \cdot 3.4$ Interpretação definida ..................... 51

$5 \cdot 3 \cdot 5$ Interpretação indefinida . . . . . . . . 54

5.4 Considerações . . . . . . . . . . . . . . . . 55

6 Kel e a definitude $\quad 57$

6.1 Introdução . . . . . . . . . . . . . . . . 57

6.2 A noção de definitude em Heim (1982) . . . . . . . . . 58

6.3 A definitude segundo C. Lyons (1999) . . . . . . . . . . . 6o

6.4 Artigo definido versus demonstrativo . . . . . . . . . . . 63

6.5 Comportamento de kel no caboverdiano . . . . . . . . 64

6.5 .1 Análises de kel................. 65

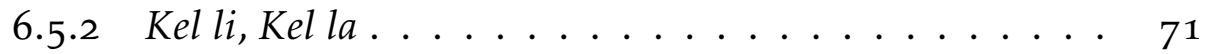

6.5.3 Kriyol da Guiné-Bissau e o caboverdiano . . . . . 73

6.5 .4 Kel li versus Es (li) . . . . . . . . . . . . . . . 74

6.6 Considerações do capítulo . . . . . . . . . 76 
$\begin{array}{lll}7 \text { Uma } & 78\end{array}$

7.1 Situando a questão . . . . . . . . . . . . 78

7.2 Por que uma não seria um artigo indefinido? . . . . . . . . 79

$7 \cdot 3$ Modificadores de grau: discussão teórica . . . . . . . . . 80

7.4 Por que uma tampouco seria um modificador de grau? . . . 82

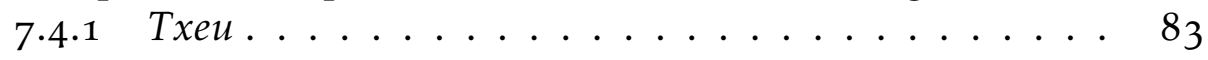

$7 \cdot 4.2$ Uma.................... 86

-óna..................... 89

Adjetivos que expressariam grau . . . . . . . 90

$7 \cdot 5$ Evidenciais: abordagem teórica . . . . . . . . . . . . 91

7.6 Uma seria um operador ilocucionário? . . . . . . . . . . 93

$7 \cdot 7$ Uma como "singularizador" . . . . . . . . . . . . 96

7.7.1 Experiência pessoal do falante . . . . . . . . 97

$7 \cdot 7.2$ Necessidade explicativa . . . . . . . . . 98

7.7.3 Interação com os elementos que expressam grau . . 100 Ocorrência com eventos valorizados negativamente 104

7.8 Considerações do capítulo . . . . . . . . . . 104

8 Considerações Finais 106

$\begin{array}{ll}\text { Referências bibliográficas } & 108\end{array}$

$\begin{array}{ll}\text { Anexos } & 114\end{array}$

$\begin{array}{lr}\text { Roteiro Kel } & 115\end{array}$

$\begin{array}{lr}\text { Roteiro Uma } & 117\end{array}$ 


\section{CAPÍTULO 1}

\section{Apresentação}

O caboverdiano oferece sérios desafios para o linguista. Nesta língua estão questões de notória dificuldade de serem abordadas, particularmente no que diz respeito ao sintagma nominal e ao paradigma pronominal ${ }^{1}$.

No que diz respeito ao sintagma nominal do caboverdiano, o fato de possuir características não atestadas em outras línguas próximas acaba por despertar o interesse dos estudiosos da língua. Os nomes no caboverdiano, em geral, não são acompanhados de qualquer determinante e podem ser interpretados tanto como definidos quanto indefinidos. A introdução de novos referentes e expressão de quantificação pode ser associada à partícula un / uns. Sua utilização, contudo, não pode ser considerada frequente em caboverdiano. A língua lança mão ainda da partícula $\mathrm{kel} / \mathrm{kes}$ para veicular, entre outras coisas, definitude. Este emprego, todavia, também não se dá de modo usual.

Alguns autores que se debruçaram sobre o tema advogam que $\mathrm{kel} / \mathrm{kes}$ desempenha, por vezes, o papel de artigo definido na língua (ver (Alexandre and Soares, 2004), (Baptista, 2007), (Quint, 2000), entre outros). Verificaremos os argumentos utilizados para defender seu estatuto como artigo definido a fim de verificar se essa hipótese pode ser sustentada com base nos dados e na literatura semântica.

A bem da verdade, a maioria das descrições sobre o caboverdiano não manifesta acordo quanto à existência ou não de artigo definido nessa língua.

\footnotetext{
${ }^{1}$ Agradeço a banca pelas sugestões. Os erros que porventura permanecerem são de minha inteira responsabilidade.
} 
Os que afirmam sua existência parecem, muitas vezes, apresentar análises da língua centradas na descrição e análise do português, principalmente do português europeu.

Este trabalho procura realizar uma análise do caboverdiano centrada nos fatos da própria língua, investigando as diferentes estratégias de interpretação dos nomes, bem como o papel dos elementos que compõem o sintagma nominal.

O trabalho está organizado da seguinte forma: no capítulo dois abordaremos alguns aspectos do trabalho de campo, assim como a metodologia utilizada. No capítulo três versaremos sobre a formação de Cabo Verde e a consequente formação da língua caboverdiana.

No capítulo quatro apresentaremos uma visão panorâmica sobre algumas das teorias que tratam das línguas crioulas, a fim de situar o leitor sobre a maneira como essas línguas têm sido abordadas por diferentes autores.

No quinto capítulo, trataremos do sintagma nominal do caboverdiano e apresentaremos suas características gerais. Exploraremos as diferentes estratégias de interpretação definida e indefinida dos nomes, assim como da leitura genérica das sentenças.

O sexto capítulo será dedicado à análise de kel e da noção de definitude. Apresentaremos seu comportamento dentro do sintagma nominal e exploraremos os diferentes argumentos utilizados para defender seu estatuto como artigo definido.

No sétimo capítulo trataremos de $u m a$, tomado por muitos estudiosos da língua como um artigo indefinido e ainda como sendo a contraparte feminina de un. Empreenderemos uma análise semântico-pragmática desse componente da língua e mostraremos por que ele não pode ser considerado um determinante indefinido, nem tampouco a contraparte feminina de un. No oitavo e último capítulo, realizaremos as considerações finais da dissertação. 


\section{CAPÍTULO 2}

\section{Metodologia}

\subsection{Metodologia e Trabalho de Campo}

\subsubsection{Dificuldades potenciais}

Pratas (2002) faz um relato muito interessante a respeito do trabalho de campo em geral e, especialmente, de seu trabalho de campo em Cabo Verde. Embora não seja nossa intenção fazer um relato exaustivo do trabalho de campo realizado, reproduziremos um trecho do relato de Pratas que, a nosso ver, é compartilhado por quem realiza um trabalho de campo:

A busca por novas revelações, sobretudo quando implica a deslocação e a permanência do investigador em lugares longe de casa e sozinho, tendo por vezes de pagar de seu próprio bolso todas as despesas, de se alojar em condições pouco confortáveis e vendo-se obrigado a falar com pessoas que não conhece sobre um assunto que à partida pode nem lhes interessar, apresenta à partida as suas dificuldades.

(...)

A escolha do(s) informante(s) é um dos aspectos que mais peso tem na determinação do sucesso de um trabalho de campo. Conforme se acerta ou erra, pode atravessar-se um período extremamente gratificante ou inesquecivelmente penoso. Para acertar nessa escolha não há, contudo, regras fixas. Há apenas 
pistas com as quais se deve jogar, entregando a equação final à intuição.

Os trechos reproduzidos ilustram as duas grandes dificuldades do trabalho de campo: o deslocamento, que implica a estada no local em que se realiza o trabalho e todas as questões e imprevistos que podem advir desse fato, e a localização de informantes, coisa que, na grande maioria dos casos, não é uma tarefa simples, pois temos de contar sempre com a disponibilidade dos informantes e, em alguns casos, de intérpretes. No entanto, especificamente para este trabalho de campo, se analisado de modo geral, as dificuldades não foram tantas.

\subsubsection{Sobre a coleta e a transcrição dos dados}

Matthewson (2004) aponta, em seu artigo sobre o trabalho de campo em semântica, que não é possível obter informações adequadas sobre o significado somente através dos dados de conversas espontâneas. Acreditamos, contudo, que não se pode realizar elicitação controlada sem bases suficientes sobre determinados comportamentos da língua. Diante disso, iniciamos nossa análise com dados espontâneos para, a partir daí, elaborarmos testes de elicitação direta, uma vez que as análises realizadas por outros autores sobre o sintagma nominal do caboverdiano não nos oferecia uniformidade suficiente para que pudéssemos tomá-las como ponto de partida.

Essa questão é levantada pela própria Matthewson (2004), uma vez que ela afirma que o tipo de trabalho de campo em semântica requer que o pesquisador reconheça e construa sentenças gramaticais na língua-objeto. Dado que nosso objeto específico possui poucas descrições, achamos por bem iniciar os estudos com dados espontâneos. Outra razão para tanto está no fato de nosso objetivo ser uma análise do sintagma nominal em seu sentido amplo, não somente de uma característica específica.

Dimmendaal (2001) afirma que o sentido referencial do nome (em termos de definitude e especificidade) é um tópico complexo e extremamente difícil de investigar com base em elicitação. Para o autor, no final, é o texto ou conexões com o discurso em geral que provê as mais importantes pistas para a análise desse domínio gramatical. Outrossim, entender o significado de uma palavra ou sentença na língua sob investigação é provavelmente o ponto de maior desafio para o investigador. Os julgamentos de gramaticalidade dos informantes e a interpretação semântica de sentenças são usualmente voltados para a questão se tal enunciado poderia fazer sentido no mundo real. Por isso, a nosso ver, no estudo de uma língua em que não há muitos dados disponíveis para o pesquisador, faz-se importante 
primeiro entender como se dá o funcionamento dessa língua para, então, elaborar testes pertinentes.

Para a transcrição dos dados, usamos o ALUPEC - Alfabeto Unificado Para a Escrita do Caboverdiano ${ }^{1}$. O ALUPEC é um alfabeto de base latina e teve sua origem em maio de 1994, tendo sido elaborado pelo Grupo de Padronização da Lingua Cabo-Verdiana.

O alfabeto foi aprovado no ano de 1998 como modelo experimental e reconhecido pelo governo de Cabo Verde em 2005 como sistema viável para a escrita do caboverdiano, tendo sido oficializado em 2009. Embora reconhecido pelo governo, ainda há a utilização de outros modelos de escrita, usados idiossincraticamente por diferentes autores.

As glosas seguem o modelo de Leipzig Glossing Rules do Max Planck Institute, disponível em http : / / www . eva.mpg. de/. Esse modelo tem sido desenvolvido por Bernard Comrie e Martin Haspelmath, do Departamento de Linguística do Instituto Max Planck para Antropologia Evolucionária, e por Balthasar Bickel, do Departamento de Linguística da Universidade de Leipzig (Bickel, Comrie, and Haspelmath, Bickel et al.).

Sobre as glosas, é importante salientar que, quando um morfema suscita mais de uma interpretação, as duas (ou mais) interpretações estarão separadas por ponto (.). As abreviações que não constavam no modelo adotado foram acrescentadas e estão relacionadas na lista de abreviações desta dissertação.

\subsection{Sobre o corpus}

O trabalho de campo foi realizado entre os dias 28 de junho e 27 de julho de 2012, na ilha de Santiago, na região de Sotavento do arquipélago de Cabo Verde.

O corpus colhido em Cabo Verde conta com:

- dez horas de gravações de conversas espontâneas;

- testes semânticos de aceitabilidade;

- questionários ${ }^{2}$.

Além disso, para questões pontuais, após a viagem de campo, recorremos a:

\footnotetext{
${ }^{1}$ Para os dados retirados de outros autores, os exemplos serão transcritos de acordo com as fontes originais.

${ }^{2}$ Alguns dos roteiros utilizados para os testes encontram-se entre os Apêndices.
} 
- testes com falantes caboverdianos residentes no Brasil;

- testes enviados (por e-mail) a pessoas em Cabo Verde e aplicados na ilha de Santiago ${ }^{3}$;

- dados retirados de análises já realizadas por outros autores sobre o caboverdiano.

Os dados foram coletados em diferentes regiões da ilha de Santiago. As regiões foram Assomada, Porto Rincão, Fonte Lima, Cidade Velha, Calhetas de São Miguel, Engenho, Pedra Badejo, São Domingos, São Jorge e São Lourenço dos Órgãos. Optamos por essas regiões pelo fato de localizaremse mais para o interior da ilha, onde há falantes que têm pouco ou quase nenhum contato com o português, o que tornou possível o registro de uma variedade mais basiletal 4 .

Para a localização de informantes, primeiramente, realizou-se um contato com professores da Universidade de Cabo Verde (Uni-CV): Prof ${ }^{a}$ Maria de Fátima, Prof. Dr. Manuel Veiga e Prof. Antônio Francisco Afonseca Martins. A professora Maria de Fátima, por sua vez, estabeleceu contato com o professor Luís Rodrigues, da Universidade de Santiago, sem o qual esse trabalho de campo não teria sido realizado.

O Prof. Luís Rodrigues solicitou a alguns de seus alunos que ajudassem com a coleta de dados. Os alunos também serviram de intérpretes, além do próprio professor Luís, que também acompanhou uma das viagens e ajudou nas primeiras gravações. Os alunos entraram em contato com familiares e amigos que aceitaram realizar as gravações. O trabalho de campo também contou com a ajuda de outras pessoas, de extrema importância, que se dispuseram a localizar informantes e acompanhar as gravações como, por exemplo, o Sr. Francisco Lopes Moreira, da Cidade Velha.

Em termos logísticos, para a realização do trabalho de campo, o deslocamento deu-se em transporte público, por meio de ônibus, das hiaces, uma espécie de van - em geral com muito mais passageiros do que sua capacidade - , e, para os locais mais distantes, os chamados "carros de caixa" 5 . A utilização de transporte público permitiu maior contato com a

\footnotetext{
3 Para tanto, contamos com a colaboração do professor Luís Rodrigues, da Universidade de Santiago.

${ }^{4}$ Uma variedade basiletal é tida como possuidora de características mais próximas das línguas de substrato, ao passo que a variedade acroletal possuiria características mais próximas da língua lexificadora. Entre essas duas variedades estaria o mesoleto. Considerando-se o caso de Cabo Verde, as variedades basiletais seriam as que possuem quase ou nenhum contato com o português e a variedade acroletal, por sua vez, estaria em contato com o português.

${ }^{5}$ Pequenas caminhonetes em que os passageiros vão na parte de trás.
} 
língua, além, é claro, da cultura. As gravações foram realizadas nas casas dos respectivos informantes. Apresentamos o mapa da ilha de Santiago.

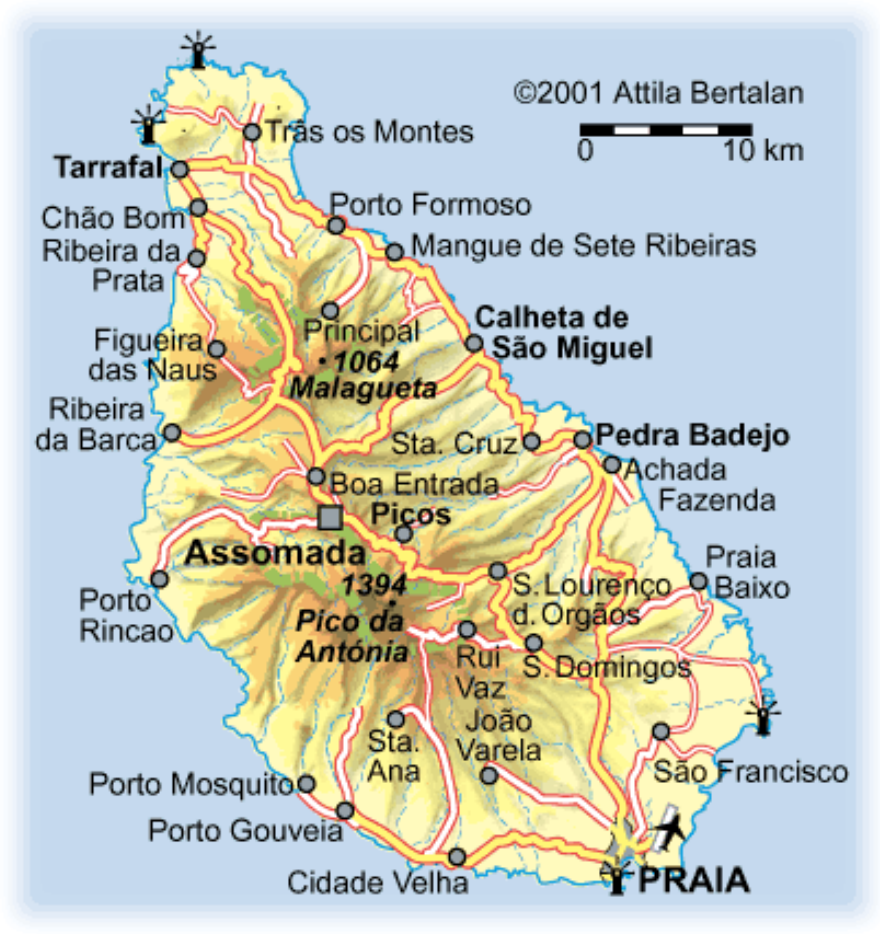

Figura 2.1: Mapa da ilha de Santiago. Fonte: Pereira (2006)

Em relação aos dados, priorizou-se a gravação de conversas espontâneas à elicitação de dados - embora tenham sido aplicados pontualmente testes de aceitabilidade e questionários. As conversas foram conduzidas por tópicos pertinentes a cada local ${ }^{6}$. A partir da análise dos dados retirados das conversas espontâneas, elaboraram-se testes específicos para a verificação de determinados comportamentos evidenciados durante a análise.

A viagem contou com o financiamento parcial do Departamento de Linguística da Faculdade de Filosofia, Letras e Ciências Humanas da Universidade de São Paulo. Os equipamentos para a gravação dos dados foram cedidos por docentes da universidade: a $\operatorname{Prof}^{a} \operatorname{Dr}^{a}$ Margarida Petter, do Departamento de Linguística, e a $\operatorname{Prof}^{a} \operatorname{Dr}^{a}$ Márcia Santos Duarte de Oliveira, do Departamento de Letras Clássicas e Vernáculas.

\footnotetext{
${ }^{6}$ Em Rincão, uma vila de pescadores, por exemplo, a conversa foi conduzida com base no tópico da pesca, sempre contando com a presença de um intérprete a fim de utilizar-se o mínimo possível de português.
} 


\subsection{Um detalhe ortográfico}

Outra questão metodológica é o motivo pelo qual escrevemos caboverdiano, sem hífen. Nossa posição está em consonância com a de Veiga (2004:9). O autor prefere que assim seja representado por tratar-se da língua materna dos caboverdianos e ainda por analogia a outros povos e suas respectivas línguas. Veiga observa que não se trata de um erro; quando muito, é uma representação que não está conforme com a norma portuguesa. Explica ainda:

Razões de nossa opção: caboverdiano vem de Cabo Verde. Mas Cabo Verde não é um cabo que é verde. O mesmo representa um único monema. Por isso, se é tolerável a representação de Cabo Verde em duas palavras o mesmo não se pode dizer em relação a caboverdiano. Uma outra razão: o elemento "verdiano" não é um monema autónomo e o hífen que separa as duas unidades (de um mesmo monema) não faz sentido.

Em suma, as razões pela não utilização do hífen configuram-se mais como um posicionamento teórico do que uma tentativa de transgressão da norma ortográfica. 
CAPÍTULO 3

A terra e a língua

\subsection{Formação de Cabo Verde e a consequente for- mação do caboverdiano}

\subsubsection{Aspectos geográficos}

O arquipélago de Cabo Verde está situado na zona tropical do Atlântico Norte a cerca de quatrocentos e cinquenta quilômetros da costa senegalesa. É composto por dez ilhas e alguns ilhéus de origem vulcânica. Das ilhas, Santiago é a maior e Santa Luzia a menor; as ilhas estão distribuídas em dois grupos tradicionais, de Barlavento, ao norte, e de Sotavento, ao sul.

Pela sua posição geográfica, Cabo Verde marca a extremidade ocidental da faixa do Sahel ${ }^{1}$, caracterizada por condições climáticas de aridez e semiaridez.

${ }^{1}$ O Sahel é a região da África situada entre o deserto do Saara e as terras mais férteis do sul que formam um corredor ininterrupto do Atlântico ao Mar Vermelho. Normalmente, incluem-se no Sahel o Senegal, a Mauritânia, o Mali, o Burkina Faso, o Níger, a parte norte da Nigéria, o Chade, o Sudão, a Etiópia, o Djibouti e a Somália. 


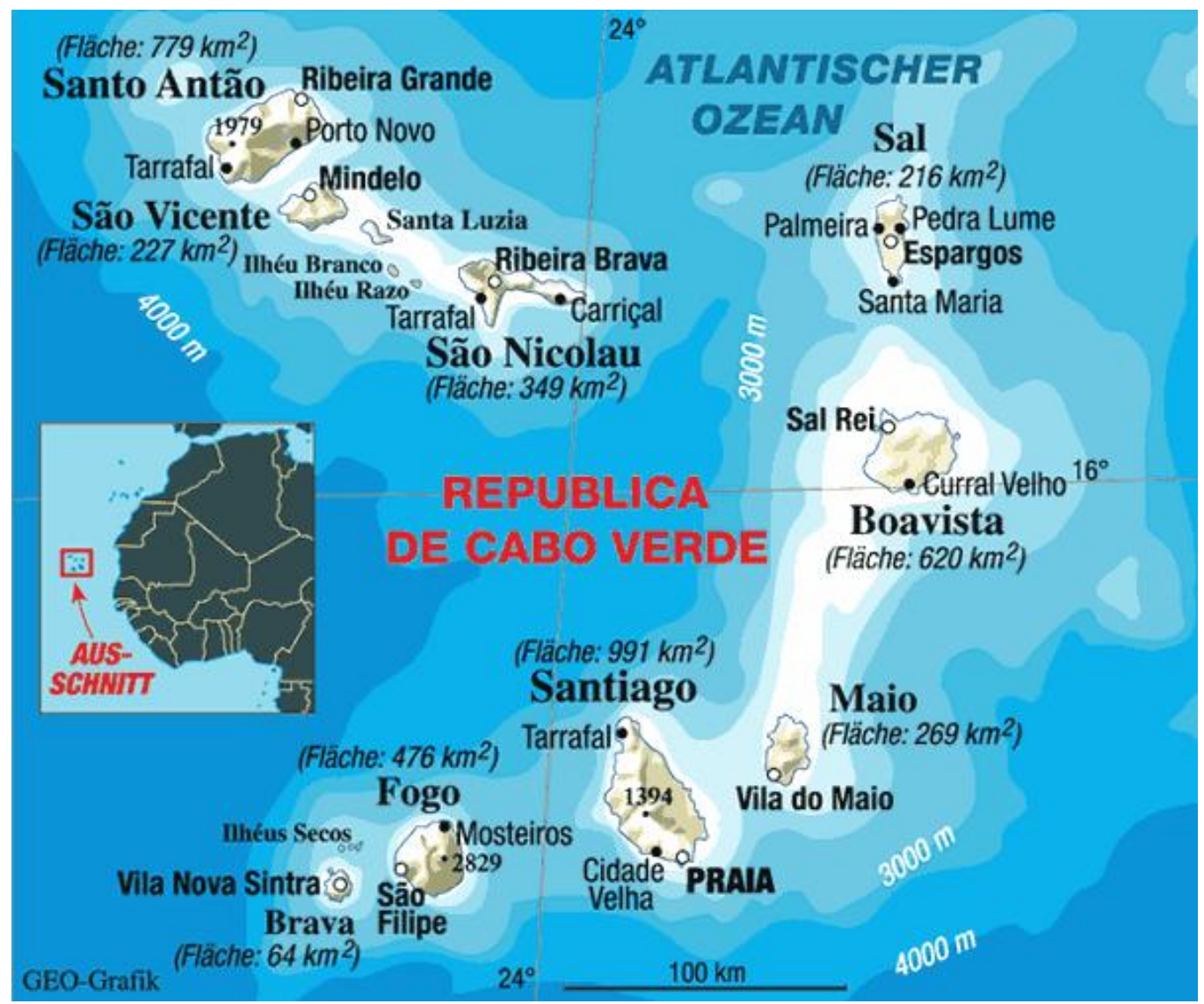

Figura 3.1: Mapa do arquipélago de Cabo Verde. Fonte: http: / /www.hidroex . mg.gov.br

\subsubsection{Aspectos sócio-históricos}

Relatos históricos afirmam que o arquipélago era desabitado quando da chegada dos portugueses, na segunda metade do século XV. A situação geográfica da ilha, desde o primeiro momento, foi considerada favorável ao comércio escravocrata. Do século XV aos princípios do século XVII, o tráfico alcançou a sua mais alta expressão, sendo as atuais ruínas da então Cidade da Ribeira Grande (hoje Cidade Velha) o principal ponto do sistema escravocrata (Veiga, 2002).

Por não ter riquezas naturais abundantes e significativas, o grande trunfo de Cabo Verde, para Santos et al. (2007), foi a sua capacidade em desempenhar um papel ativo nas redes de troca e circulação de escravos e mercadorias entre diferentes locais. Essa troca envolve, entre os séculos XVI e parte do XVII, os Rios da Guiné, Portugal, as ilhas atlânticas, Castela 
e, posteriormente, Índia, França, Holanda, Brasil e outros.

Veiga (2002) observa que a ilha de Santiago e, em especial, a Cidade de Ribeira Grande, funcionou, na época, como um grande motor do tráfico escravocrata: os escravizados eram capturados em grande quantidade na Costa Ocidental da África e, seguidamente, eram trazidos para a Ribeira Grande, onde aprendiam os rudimentos da língua e da religião. Depois, eram exportados tanto para a Europa quanto para a América do Sul.

No século XVI, a economia escravocrata atingiu seu auge, tendo começado a declinar a partir das primeiras décadas do século XVII. O sistema, porém, só seria banido em Cabo Verde na segunda metade do século XIX.

Para a formação da sociedade caboverdiana contribuem povos de duas áreas geográficas bem distintas, a saber, os portugueses, primeiramente oriundos do norte de Portugal, e os africanos. Além dos portugueses, há documentos que atestam a presença de genoveses já em 1466. A presença dos castelhanos também era significativa. Os europeus vão concentrarse sobretudo na Ribeira Grande, mas o número nunca atingiu grandes proporções, se comparado, relativamente, aos africanos.

As origens étnicas do contingente africano dificilmente podem ser esclarecidas por documentações quinhentistas. Durante o primeiro século da história de Cabo Verde, não há referência às origens étnicas dos africanos. A posição mais aceita é que o maior número dos escravos era proveniente dos grupos localizados na região da costa da Guiné, que se estendia desde a margem sul do rio Senegal ao rio Orange, no limite norte de Serra Leoa. António Carreira (1983) aponta para vinte e sete grupos étnicos e alguns subgrupos.

Quint (2010) assinala que as línguas africanas mais faladas em Cabo Verde na época eram o uólofe, o mandinga e o timené. Segundo o autor, essas línguas contribuíram fortemente para a formação do caboverdiano. As etnias jalofa, mandinga e papel são citadas por Pratas (2002) como as mais proeminentes. Já Baptista (2007) aponta para os grupos mandinga, jalofos e fulas pretos como os mais proeminentes.

Brásio (1962), citado por Baptista (2007), com base no censo de 1856, assinala os mandingas, os balantas, os bijagós, os felupes, os beafadas, os papels, os kissis (kizis), os brames, os banhuns, os peuls, os jalofos, os bambaras, os bololas e os manjacos como os principais povos que contribuíram para a formação do caboverdiano. Por aí se vê a dificuldade de se afirmar com certeza quais as etnias originárias do continente africano que tomaram parte da formação do caboverdiano.

Apesar dos relatos dos diferentes autores, não é possível atestar, com exatidão, quais as línguas, além do português europeu, que realmente contribuíram para a formação do caboverdiano. 
Sobre as condições que favoreceram a formação da língua, podemos citar, em primeiro lugar, a questão geográfica, por se tratar de uma ilha e o multilinguismo existente.

Veiga (2002) assinala, entre as condições que favoreceram a emergência do caboverdiano, o fato de, além dos escravizados pertencerem a diferentes etnias, o número de negros sempre ter sido mais elevado que o número de brancos. A permanência transitória também pode ser levada em conta: os escravizados ficavam o tempo necessário para aprender os rudimentos do serviço e da língua e, posteriormente, eram comercializados.

Pode-se citar também o fato de que os brancos, além de estar em número reduzido, falavam diversos dialetos do português europeu. A urgência da comunicação entre eles, guiada pelos interesses econômicos, também deve ser levada em conta.

Devido à conjuntura daquela dada situação, não foi possível a imposição de nenhum dos códigos linguísticos conviventes na ilha naquele período, o que levou à emergência de um novo código linguístico, diferente de todos aqueles que coexistiam naquele mesmo ambiente. A língua caboverdiana estava, de acordo com Veiga (2002:15), fortemente estabelecida no século XIX e início do século XX.

\subsection{Das características da língua caboverdiana}

\subsubsection{Língua materna versus língua oficial}

Antes de elencarmos as características morfossintáticas da língua, é importante observar, mesmo que de modo breve, a situação político-social das duas línguas faladas no país.

Embora a língua portuguesa seja a língua oficial de Cabo Verde, ela é restrita às salas de aula, às cerimônias oficiais e aos meios de comunicação. O caboverdiano é amplamente falado no país. Há uma movimentação por parte de intelectuais e alguns políticos para a oficialização da língua, mas, por ora, o português ainda figura como língua oficial e de ensino. Um dos nomes mais representativos em defesa da oficialização do caboverdiano é o Prof. Dr. Manuel Veiga, com diversas publicações sobre a língua, inclusive dicionários.

É interessante notar, porém, que, apesar de o caboverdiano ser uma língua relativamente estudada, com gramáticas, dicionários e até manuais, inclusive de bolso, a grande maioria da população não tem notícia nem acesso a esses trabalhos, ficando restritos ao meio acadêmico.

A despeito de muitos afirmarem que todos os caboverdianos compre- 
endem e até mesmo falam o português, não é o que se observa em todos os lugares, ao menos não em Santiago, existindo muita dificuldade de comunicação em português, sendo necessária a presença constante de um intérprete. Há, ainda, opiniões divergentes quanto à oficialização do caboverdiano, mas há também, por outro lado, um interesse por grande parte dos caboverdianos de que sua língua materna seja oficializada.

Conforme aponta Quint (2010), o caboverdiano não possui uma norma que seja reconhecida de forma unânime. Cada ilha do arquipélago (nove) possui sua própria variedade linguística e, ainda, a língua falada no interior das ilhas possui diferenças em relação à língua falada nas cidades. Essas diferenças, contudo, não impossibilitam a intercompreensão. São semelhantes às diferenças dialetais que encontramos no português brasileiro nas diferentes regiões do Brasil.

É importante observar a necessidade e importância da implantação do ensino do caboverdiano nas escolas. Necessidade essa tanto social quanto linguística, uma vez que são notáveis as dificuldades engendradas em relação ao ensino escolar em língua não-materna. Veiga (2012) afirma que a "verdadeira afirmação" do caboverdiano acontecerá no dia em que este for introduzido no sistema de ensino.

Para essa implantação, contudo, é necessária, para além da formação dos professores, a elaboração de material didático em caboverdiano. Diante desse fato, vale ressaltar a importância da oficialização, em 2009, do ALUPEC ${ }^{2}$.

Os diferentes trabalhos realizados mais recentemente sobre o caboverdiano fazem uso do ALUPEC para a transcrição dos dados, o que possibilita uma uniformização da escrita e maior intercompreensão. Outrossim, as análises empreendidas por diferentes autores de diferentes partes do mundo representam um número suficiente para servir de base para o início da elaboração de materiais didáticos, o que poderia configurar-se como um dos primeiros passos para a implantação do ensino escolar da língua materna em Cabo Verde.

\subsubsection{Caraterísticas morfossintáticas da língua}

Apresentamos a seguir apenas as características que serão pertinentes a esta dissertação. Antes de mais nada, em caboverdiano, as flexões, tanto

\footnotetext{
${ }^{2}$ Não entraremos na discussão sobre as diferenças dialetais, nem tampouco qual a variedade mais representativa. Apontamos, porém, paralelamente às discussões geradas a cerca desse tema, para a necessidade maior que é a implementação do ensino do caboverdiano nas escolas.
} 
nominais como verbais, são em número reduzido quando comparadas às das línguas flexionais em geral.

\section{Número}

Quanto ao número, a língua distingue entre singular e plural apenas em nomes de seres animados. Na visão de Quint (2000:325), entretanto, o emprego do plural seria obrigatório quando se trata de seres humanos e opcional nos outros casos.

O plural é marcado através de um marcador que faz referência direta à quantidade — dôs ("dois") ou txeu ("muito"), por exemplo — e, em número menor, com o sufixo - $(i)_{s}$ em final de palavra. Observa-se também, a ausência de redundância na morfologia de número (Veiga, 2002).

Para estabelecer uma comparação, em termos da utilização do plural na língua, pode-se dizer que, em caboverdiano, o uso do plural é menos frequente que no português, por exemplo. Quint (2010) apresenta alguns princípios que restringem o uso do plural:

1. Princípio contextual: caso um elemento do contexto indique que o nome está no plural, a marcação do plural torna-se desnecessária, como em (1).

(1) $\mathrm{N}$ ten tres fidju.

1SG ter três filho

Eu tenho três filhos.

(Quint, 2010:214)

2. Princípio da marca única: seria a marcação não redundante do plural, conforme (2).

(2) kes katxor.

DEM.PL cachorro

Aqueles cachorros.

(Quint, 2010:214)

3. Princípio semântico: salvo raras exceções, somente nomes que se referem a seres animados podem receber a marca do plural. Fora esses casos, o plural é marcado com uma referência direta à quantidade (dôs, tres...), ou através de advérbios (txeu, poku...), ou ainda através do indefinido (uns) ou demonstrativo (kes). 


\section{Gênero}

No que concerne ao gênero, o caboverdiano geralmente não distingue entre masculino e feminino. A exceção é verificada, porém, quando se refere a seres sexuados (seres humanos e outros animais).

Quint (2010:215) divide as formas femininas em lexicais, analíticas e sintéticas ${ }^{3}$.

- Formas lexicais:

ómi (homem) $\neq$ mudjer (mulher)

pai (pai) $\neq$ mai (mãe)

boi (boi) $\neq$ báka (vaca)

- Formas analiticas:

fidju mátxu (filho) $\neq$ fidju fémia (filha)

kátxor mátxu (cão, cachorro) $\neq$ katxor fémia (cadela)

- Formas sintéticas:

tiu $($ tio $) \neq t i \hat{a}($ tia $)$

pursor (professor) $\neq$ pursóra (professora)

trabadjador (trabalhador) $\neq$ trabadjadera (trabalhadora)

Em Quint (2000:154), o autor observa que, em caboverdiano, as noções de feminino ou ainda de plural diferem grandemente da percepção que se tem (sobre essas mesmas noções) em português, espanhol ou francês. A compreensão precisa das marcas de número e gênero em caboverdiano passam, de acordo com o autor, por uma visão mais englobante da língua.

\section{Pronomes Pessoais}

Sobre os pronomes pessoais, é importante salientar os pronomes tônicos iniciais, ou pronomes fortes, que ocorrem, em geral, em início de sentenças - ou isoladamente - e possui função de reforço. Apresentamos na Tabela 3.1 as expressões pronominais do caboverdiano retirado de Pratas (2002:42).

\footnotetext{
${ }^{3}$ A distinção entre as formas lexicais e sintéticas, contudo, pode não ser evidente.
} 
3.2 Características do caboverdiano

\begin{tabular}{|c|c|c|c|}
\hline & Fortes & $\begin{array}{l}\text { Fracos } \\
\text { (clíticos tônicos) }\end{array}$ & $\begin{array}{l}\text { Clíticos } \\
\text { átonos }\end{array}$ \\
\hline $1^{\mathrm{a}}$ singular & ami & $\mathrm{mi}$ & $\mathrm{N} /-\mathrm{m}$ \\
\hline $2^{\mathrm{a}}$ singular (informal) & abo & bo & $\mathrm{bu} /-\mathrm{u}$ \\
\hline $2^{\mathrm{a}}$ singular (formal, masc) & anhu & nhu & nhu \\
\hline $2^{\mathrm{a}}$ singular $($ formal, $\mathrm{fem})$ & anha & nha & nha \\
\hline $3^{\mathrm{a}}$ singular & ael & el & e/ -1 \\
\hline $1^{\mathrm{a}}$ plural & anos & nos & $\mathrm{nu}$ \\
\hline $2^{a}$ plural & anhos & nhos & nhos \\
\hline $3^{a}$ plural & aes & es & $-s$ \\
\hline
\end{tabular}

Tabela 3.1: O sistema pronominal do caboverdiano (listagem parcial).

Além dos pronomes apresentados acima, o caboverdiano possui ainda os pronomes de sujeito enclíticos, os pronomes átonos de objeto, os possessivos átonos e os possessivos tônicos. Não iremos, contudo, apresentar as tabelas de todos os pronomes, somente os que serão relevantes aos nossos objetivos.

É importante observar que a reflexividade e a reciprocidade são expressas (quando o contexto não as torna evidente) pelas palavras kabésa "cabeça", como o exemplo em (3) e kunpanheru "companheiro", conforme exemplificado em (4).

(3) $\mathrm{N} \varnothing$ odja nha kabésa na spedju. 1SG PFV olhar 1 SG.POSS cabeça.PRON.REFL PREP espelho Eu me olhei no espelho.

(Brüser et al., 2001:32)

(4) Es kre kunpanheru.

3PL querer companheiro.PRON.REFL

Eles se gostam.

(Brüser et al., 2001:32)

\section{Domínio Verbal}

Na conjugação verbal, o sujeito é sempre expresso. Quanto à flexão, a língua possui três desinências temporais, a saber, $-b a$, em (5), $-d u$, em (6) e -da, em (7). Todavia, os verbos, em sua grande maioria, não se flexionam em função de pessoa, tempo ou número. Brüser et al. (2001) assinalam as desinências $-b a,-d u$ e $-d a$ como marcadoras de "anterioridade", "passividade" 
e "anterioridade + passividade", respectivamente ${ }^{4}$.

(5) Zináida ta kantába sábi.

Zinaida HAB cantar.PST.IMPF bem

Zinaida cantava bem.

(Quint, 2009:48)

(6) El fládu.

Ele falar.PST

Ele tinha falado.

(7) Pedru fláda ma Pálu $\varnothing$ móri.

Pedro falar.PST que Paulo PFV morrer

Pedro tinha dito que o Paulo morreu.

(Quint, 2009:50)

As noções de tempo, modo e aspecto são, na grande maioria dos casos, veiculadas por uma partícula pré-verbal. As partículas pré-verbais são invariáveis, sempre precedem o verbo e combinam-se somente na forma de uma por verbo (Quint, 200o). As partículas aspectuais são:

- Ta: marca o aspecto imperfectivo, ou habitual. Indica que a ação é praticada habitualmente, independente do tempo, conforme (8). Ademais, de acordo com Brüser et al. (2001), a partícula marca também "imperfectividade", englobando"iteratividade", "habitualidade" e "futuridade".

(8) Djon ta kánta.

João HAB cantar

O João canta (habitualmente).

(Quint, 2010:246)

- Sata: marca o aspecto progressivo ou durativo, como em (9).

(9) Djon sata kánta.

João PROG cantar

O João está cantando.

(Quint, 2010:247)

- Dja: marca o aspecto pontual. Indica que a ação acabou de ser realizada logo antes do momento da enunciação, conforme exemplo

\footnotetext{
${ }^{4} \mathrm{~A}$ distinção entre as desinências - $d u$ e $-d a$ parece residir mais no domínio aspectual do que temporal e pode, contudo, não ser evidente.
} 
em (10).

(10) Djon dja kánta.

João PON cantar

O João acabou de cantar.

(Quint, 2010:247)

- Ál: marca o aspecto potencial ou eventual. Indica que a ação é suscetível de ocorrer, exemplificado em (11).

(11) Djon ál kánta.

João POT cantar

Talvez (é possível que) o João cante.

(Quint, 2010:247)

A ausência de qualquer marca aspectual antes de verbos não-estativos indica o aspecto perfectivo, que será marcado nos dados com o símbolo $\varnothing$. A negação verbal é indicada pela partícula $k a$ e ocorre, regularmente, entre o sujeito e a partícula aspectual.

Quint (2010:249) observa que "não existe um sistema de equivalências simples entre o sistema aspecto-voz-tempo do caboverdiano e o sistema modo e tempo do português." Assinala ainda que seria impossível dizer a que forma determinada combinação de tempo-modo-aspecto do caboverdiano corresponderia exatamente tal ou tal flexão verbal do português. Em outras palavras, seria praticamente impossível estabelecer uma correspondência exata entre o sistema verbal das duas línguas.

Para finalizar, o verbo ser é apresentado pelo autor como exceção às regras aplicadas aos demais verbos da língua por não possuir uma forma passiva e por sua flexão não ser derivada do radical, exceto pela forma do passado regular:

- presente: el é (ele é)

- passado: el éra (ele era)

- passado regular: el serba (ele ia ser)

A forma do presente é, em geral, elidida, principalmente em contextos exclamativos, em (12), na presença da partícula de negação $k a$, exemplificado em (13) e em expressões comparativas, como em (14): 
(12) Káru bunitu!

Carro bonito

Este carro é bonito.

(Quint, 2010:253)

(13) Djon ka mutu spértu.

João NEG muito esperto

O João não é muito esperto.

(Quint, 2010:253)

(14) Djon más grándi ki Pálu.

João ADV grande PRON.CONJ.PREP Paulo

O João é maior que o Paulo.

(Quint, 2010:253)

A língua possui ainda, outras especificidades quanto o domínio verbal que não serão contemplados no presente trabalho. Optamos por apresentar apenas as características relevantes à análise apresentada no decorrer da dissertação. 


\section{CAPITULOO 4}

\section{Línguas Crioulas}

\subsection{Introdução}

A formação das línguas crioulas e seu estatuto são temas que, para os estudiosos da área de crioulística, independentemente de seu objeto de estudo, não podem ser colocados de lado, por constituírem um debate ainda presente para os pesquisadores da área.

Não é de nosso intento, todavia, realizar uma apresentação exaustiva dos autores e trabalhos que se debruçaram sobre o tema pois, como é sabido, há estudiosos que já o fizeram minuciosamente. Nem tampouco pretendemos empreender uma historiografia sobre a discussão gerada acerca do tema. Apresentaremos aqui, de modo sucinto, alguns dos trabalhos pertinentes sobre a formação das línguas crioulas, bem como as diferentes correntes existentes.

Assumimos, porquanto, que nomes como Holm (2004) e McWhorter (2005) seriam, também, importantes para a discussão desse tema. Todavia, por uma questão de tempo e por não ser esta uma dissertação sobre todas as teorias que versam a respeito das línguas crioulas, esses autores não estão aqui contemplados. Entretanto, sublinhamos a importância deles para o debate ${ }^{1}$.

${ }^{1}$ Nesse capítulo exploramos algumas teorias - mais antigas - que versam sobre o surgimento das línguas crioulas. Admitimos que não contemplamos trabalhos mais recentes sobre o debate, o que poderia ter levado a uma discussão mais produtiva sobre o tema. Agradecemos a banca pelas sugestões a respeito desse capítulo e afirmamos que os 


\subsection{Um breve panorama dos estudos sobre o sur- gimento das línguas crioulas}

O estudo das línguas crioulas, como campo de pesquisa sistemático, traz Coelho (1881) e Schuchardt (1882) como precursores. Todavia, o estatuto dessas línguas tem sido fonte de grande debate ao longo dos estudos na área. Crioulistas não concordam quanto à definição dos termos pidgins e crioulos, nem sobre o status de um número de línguas que se tem afirmado pertencer a tal classificação. Para Muysken and Smith (1994), devemos olhar para a história, linguística ou social — de preferência as duas -, antes de classificarmos uma determinada língua como crioula.

Na mesma esteira de pensamento, Arends (1994) reforça a necessidade de olhar para a história dessas línguas, embora, como é sabido, não seja possível estabelecer uma história comum para todas as línguas crioulas. $\mathrm{O}$ autor aponta, com base na história de formação, para três tipos de línguas crioulas: de plantação, de forte e de quilombos (maroons).

As línguas crioulas de plantação desenvolveram-se na área atlântica onde o sistema de plantation foi introduzido. Esse sistema utilizou-se de um largo número de escravos trazidos da costa africana. Importa salientar o fato de esses elementos não estarem necessariamente interligados. Em outras palavras, não podemos afirmar que, em todos os lugares onde foi implementado, o sistema de plantation teve como consequência um processo de formação das línguas crioulas, haja vista o caso do Brasil.

O segundo tipo de contexto foram os fortes. Estes eram postos fortificados, situados ao longo da costa do oeste africano, nos quais os europeus implantaram suas atividades comerciais. O caboverdiano é oriundo desse tipo de contexto sócio-histórico.

O terceiro tipo de contexto sócio-histórico, em que houve a formação de línguas crioulas, foram os quilombos, ou maroons. Nesse caso, os escravos fugidos das plantações formaram suas próprias comunidades isoladas do resto da colônia. Há relatos de comunidades quilombolas na Jamaica, Suriname, São Tomé, entre outros locais.

Para o entendimento do caboverdiano, vale ainda ressaltar a distinção entre línguas crioulas endógenas e exógenas feita por Chaudenson (1977), dado que Cabo Verde configura-se como um arquipélago sem população autóctone.

erros que porventura ainda persistirem, é de nossa responsabilidade. Alertamos ainda ao leitor que, caso tenha um interesse mais direto na análise do sintagma nominal do caboverdiano, a leitura desse capítulo não interfere diretamente no entendimento das análises. 
As línguas crioulas endógenas desenvolveram-se pelo contato entre populações indígenas e um grupo imigrante. As exógenas, por seu turno, desenvolveram-se através do contato entre imigrantes e a população transplantada e são, em geral, variedades insulares. A população nativa tem um papel limitado nesse último caso, por ter sido rapidamente expulsa ou exterminada pelo processo de colonização, ou ainda, como no caso de Cabo Verde, por não haver sequer população nativa.

Um ponto que parece ser de concordância em relação à formação das línguas crioulas é que seu surgimento, na grande maioria dos casos, está ligado ao contexto de expansão colonial europeia e o consequente tráfico de escravos advindo dessa expansão. Como consequência, houve o aparecimento do sistema de plantation, introduzido pelas nações europeias em algumas colônias. Esse ambiente, segundo Arends (1994), deve ter sido um dos principais loci de crioulização.

A demografia é apontada por Arends (1994) como uma precondição ao processo de crioulização e também como um determinante da natureza desse processo. O desenvolvimento quantitativo entre as partes brancas e negras da população seria um dos fatores demográficos que poderiam contribuir para o entendimento do processo de crioulização, visto que, conforme o autor salienta, a presença de "modelos" da língua lexificadora seria uma condição necessária para a transmissão desta à população escrava.

\subsubsection{Teorias que tomam como foco o input europeu}

Sobre as teorias que tomam como foco o input europeu para explicar as línguas crioulas, den Besten et al. (1994) fazem uma divisão entre as que enfatizam uma língua europeia específica e as que acentuam a transformação das estruturas das línguas europeias.

As primeiras, conhecidas como teorias monogenéticas, afirmam, em sua forma mais radical, que todas as línguas crioulas do mundo derivaram de um único pidgin, de base lexical portuguesa, falado na costa do oeste africano. Já as teorias que acentuam a transformação das estruturas das línguas europeias dividem-se, por sua vez, entre a suposição de que os próprios europeus simplificavam suas línguas quando falavam com os africanos - é a chamada hipótese baby talk/foreigner talk — e a hipótese de aprendizado imperfeito de segunda língua pelos africanos.

\section{Teorias monogenéticas}

Apresentam, basicamente, duas versões. A primeira afirma que todas as línguas crioulas teriam sido derivadas do pidgin português do oeste africano 
(WAPP — West African Pidgin Portuguese); a segunda, além de incorporar a primeira hipótese, assevera também que esse pidgin teria sido derivado, por sua vez, de uma língua franca do mediterrâneo.

A teoria da monogênese esteve em voga nas décadas de sessenta e setenta do século XX e foi primeiramente articulada por Taylor (1961) e Thompson (1961). Esses autores presumiram que o WAPP teria sido falado do século XV ao XVII em vários fortes e comércios realizados, pelos portugueses, ao longo da costa da África ${ }^{2}$.

Um desenvolvimento dessa hipótese alega que o WAPP teria provindo, por meio do processo de relexificação, de uma língua franca falada no mediterrâneo ${ }^{3}$. den Besten et al. (1994) reconhecem que o papel de uma língua franca na formação do WAPP não poderia ser negado, entretanto não pode ser confirmado também. Salientam ainda que a ideia de que todos os pidgins e línguas crioulas tenham derivado de um único caso de pidgnização é completamente irracional, pois um exemplo único de qualquer tipo de fenômeno ligado à atividade conceptual humana é simplesmente inconcebível.

\section{Foreigner talk e baby talk}

Nessa perspectiva teórica, o resultado que tem sido chamado na literatura sociolinguística de foreigner talk, ou seja, a simplificação da fala pelos nativos quando falam com estrangeiros, poderia ter se constituído como base para a formação de pidgins e, em último caso, das línguas crioulas. O foreigner talk seria resultado de pelo menos quatro processos separados: acomodação, imitação, condensação telegráfica e adoção de convenções.

Nessa esteira de pensamento, o status do falante não nativo seria um fator crucial que determinaria o tipo de contato e processos utilizados na interação de comunicação entre falantes nativos e não nativos.

den Besten et al. (1994) salientam o fato de que, qualquer que seja o mérito da teoria do foreigner talk, ela claramente corre o risco de ser circular e faz certas predições específicas que não são corroboradas. O risco de circularidade liga-se ao fato de que, uma vez que as formas do foreigner talk são, em geral, modeladas em pidgin, esse último pode, erroneamente, ser pensado como tendo surgido do primeiro. Ademais, para os autores, os pidgins e línguas crioulas parecem ser mais um resultado de aprendizado

\footnotetext{
${ }^{2}$ Para explicar a existência das línguas crioulas de base lexical francesa e inglesa, entre outras, a teoria afirma que estas teriam surgido igualmente do WAPP, e que teriam sofrido um processo de relexificação.

3 Esse primeiro pidgin, de base lexical italiana/provençal, teria existido por volta do ano 1000, embora os primeiros registros tenham sido feitos apenas no século XIV.
} 
de segunda língua do que de foreigner talk.

\section{Aprendizagem imperfeita de segunda língua}

O primeiro estudioso a propor que os pidgins são resultado de aprendizagem imperfeita de segunda língua (L2) foi Coelho (1881). Nessa perspectiva teórica, são levantadas algumas características de "sistemas de interlíngua" que podem ser encontrados em pidgins e línguas crioulas:

a. formas verbais invariáveis, derivadas ou do infinitivo ou da forma verbal menos marcada;

b. não uso de determinantes ou, em alguns casos, uso de demonstrativos como determinantes;

c. posição invariável da partícula de negação pré-verbal;

d. uso de advérbios para expressar modalidade;

e. uma única ordem de palavra fixa, sem inversão de questões;

f. redução ou ausência de marcação plural nominal.

\subsubsection{Teorias que focam o input não europeu}

Aqui, três conceitos são de fundamental importância, a saber, substrato, superstrato e adstrato. O termo substrato tem origem na linguística histórica e geografia dialetal do século XIX e refere-se à língua ou dialeto do grupo de menor prestígio dentro da situação de contato linguístico. De modo similar, a língua do grupo que possui alto prestígio é denominada superstrato ou superstratum e, finalmente, duas línguas que possuíam igual prestígio na situação de contato eram denominadas adstratos ${ }^{4}$.

Além do fato de referir-se à línguas particulares na situação de contato, os três termos são utilizados também para referir-se a efeitos causados por essas línguas nas que resultaram do contato linguístico.

Arends et al. (1994), ao abordar a questão do substrato na formação das línguas crioulas, apontam para o problema metodológico conhecido como o Princípio da Cafeteria.

"Nos estudos das línguas crioulas, o termo "adstrato" geralmente é utilizado para referir-se à línguas que estiveram envolvidas na formação sem pertencer ao substrato ou superstrato. 
Esse termo foi cunhado por Dillard (1970) para referir-se à prática de atribuir, arbitrariamente, características de línguas crioulas de base lexical inglesa à influência do superstrato de vários dialetos ingleses.

Nesse sentido, considerando as teorias que tomam como foco o input não europeu, ou seja, que enfatizam as características do substrato, o Princípio da Cafeteria referir-se-ia a um processo similar, mas no sentido oposto, na ordem de "demonstrar", por meio de explicações ad hoc, influências de uma língua particular do oeste africano em determinada língua crioula.

Outro problema metodológico seria estabelecer, com algum grau de certeza, qual ou quais substratos tiveram papel numa dada característica de determinada língua crioula. Ao lado desses problemas metodológicos, há ainda um problema empírico, que consiste em saber quais línguas do substrato estiveram na situação de contato e ainda quando e qual o número de falantes de cada língua.

Os autores, todavia, apontam que a influência direta do substrato pode ser observada na fonologia, morfologia e sintaxe das línguas crioulas. Um exemplo na fonologia é a estrutura silábica das línguas crioulas surinamesas, que difere de sua língua lexificadora, a inglesa, aproximando-se de línguas como gbe $(\mathrm{CV}, \mathrm{CV})$ e kikongo $(\mathrm{CV}, \mathrm{CVV}, \mathrm{CVVN})$, além de possuir tons distintivos.

Na morfologia, a influência africana pode ser constatada, por exemplo, nos afixos aspectuais do berbice dutch (BD), o qual replica completamente

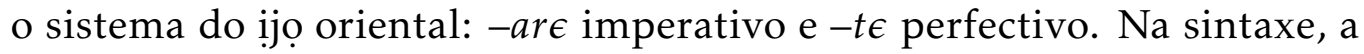
característica mais apontada como influência do substrato é a construção serial verbal. Esse tipo de construção é a pontado pelo autores como relativamente raro entre as línguas do mundo, exceto para línguas sino-tibetanas, línguas papua e um número bastante representativo de línguas do oeste africano, tais como akan, gbe, gã e kru. Observem-se os exemplos (1) e (2) retirados de Arends et al. (1994:107):

\section{Saramacan}

(1) A tei goni suti di pingo. 3SG pegar arma atirar DET porco Ele atirou no porco com uma arma.

\section{Akan}

(2) Ode adare no twaa nkromata. he-take machete DET cortar.PST galho

Ele cortou o galho com um facão. 
Quanto à semântica, Arends et al. (1994) salientam que há poucos estudos na área quanto ao papel da influência do substrato, e chamam a atenção para um estudo comparativo, realizado por Huttar (1975), entre o ndjuka e outras quarenta e três línguas 5 .

\subsubsection{Hipóteses gradualistas}

Arends and Bruyn (1994) afirmam que alguns crioulistas compartilham da visão de que as línguas crioulas, por definição, emergiram de pidgins por meio do processo de nativização. Essa noção foi adaptada por Mühlhäsler (1986) com o nome de developmental continuum.

Contrastando com a hipótese da crioulização como um processo "abrupto" ou "instantâneo", desenvolveu-se, durante o final dos anos oitenta e início dos anos noventa do século XX, o Modelo Gradualista (Carden and Steward, 1988); (Arends, 1993) ou Hipótese de Crioulização Gradual (McWhorter, 1992).

Com base em documentos históricos, os autores apontam que a taxa de nativização das sociedades escravas — ou seja, a taxa em que a proporção dos negros localmente nascidos e dos trazidos do continente africano mudou em favor dos primeiros - foi tão lenta que parece improvável que o processo de crioulização tenha se dado de modo instantâneo. Outra possível evidência trazida à baila pelos autores é o fato de um número de pidgins, tal como o tok pisin, ter se expandido e estabilizado antes de serem nativizados.

Essa hipótese aponta para o problema da definição de crioulização. Num sentido restrito, adotado por Bickerton (1991) e outros, crioulização é tomada como relacionada somente aos requerimentos mínimos da língua, enquanto no sentido amplo, adotado por Labov (1990) e outros, outras propriedades da língua são incluídas na definição. Ambas as visões são problemáticas. No sentido restrito, um dos problemas seria decidir quais são os requerimentos mínimos para a língua e, no sentido amplo, decidir onde a crioulização para e a mudança normal da língua começa (Arends and Bruyn, 1994).

\footnotetext{
${ }^{5}$ Neste estudo, verificou-se a extensão polissêmica de vinte morfemas do ndjuka comparando-se a quarenta e três línguas, incluindo pidgins e línguas crioulas do Caribe, oeste africano, não atlânticas e outras. As diferentes línguas foram arranjadas de acordo com o grau de semelhança de seus lexemas por relação à estrutura semântica lexical de ndjuka.
} 


\subsubsection{Abordagens universalistas}

A ideia geral é a de que aspectos universais da capacidade linguística humana são, de alguma forma, responsáveis por características específicas de pidgins e línguas crioulas. Coelho (1881), citado por Muysken and Veenstra (1994), escreve:

O crioulo românico e os dialetos indo-portugueses e todas as formações similares devem sua origem à ação de leis fisiológicas ou psicológicas [que são] as mesmas em todos os lugares, e não à influência de línguas anteriores das pessoas onde esses dialetos foram formados.

A afirmação de Coelho é direcionada primeiramente contra a ideia de influência do substrato.

No que concerne às duas concepções dominantes de universais, estes podem ser denominados de processuais e constitutivos. Os universais processuais são, como o nome indica, propriedades universais de processo, tais como gramaticalização e aprendizagem de segunda língua ${ }^{6}$.

Os universais constitutivos são propriedades do resultado de pidgins e línguas crioulas, tal como o sistema de partículas de tempo, modo e aspecto (TMA), ou ordem de palavras. Esses universais pertencem ao domínio da teoria da gramática que afirma que toda língua natural deve estar de acordo com a Gramática Universal, sendo esse "estar de acordo com" não opcional. Essa teoria, dentro da abordagem das línguas crioulas, tem Bickerton como principal expoente com seu livro Roots of language, de 1981. O conjunto total de ideias é conhecido como Teoria do Bioprograma.

De modo breve, essa teoria afirma que as línguas crioulas são "invenções" das crianças que cresceram nas plantações recém-formadas. Essas crianças teriam ouvido somente os pidgins falados pelos seus pais e teriam utilizado sua própria capacidade inata para transformar esse input em uma língua "de pleno direito".

Mesmo sem nos determos nessa hipótese, bastaria um olhar sobre os fatos históricos para indicar que ela não poderia sustentar-se. Praticamente não existiam crianças crescendo nos ambientes de plantação, pois era minúsculo o número de crianças ali nascidas, o que é ainda reforçado pela baixíssima expectativa de vida dos africanos uma vez trazidos às sociedades de plantação: entre sete e oito anos. Ou seja, a população não era fixa nem tampouco estável, o que torna impossível advogar por uma teoria que

\footnotetext{
${ }^{6}$ Esses universais possuem, em geral, uma base psicolinguística e são formulados como estratégias que um falante pode empregar em uma situação de contato.
} 
sustenta a formação das línguas crioulas na aquisição de primeira língua de crianças nascidas nessas sociedades.

\subsection{O método histórico comparativo: Thomason \& Kaufman}

No livro Language contact, creolization and genetic linguistics, de 1988, Thomason \& Kaufman advogam que pidgins e línguas crioulas não seriam geneticamente relacionados a nenhuma das línguas envolvidas no processo de formação, pelo fato de não terem surgido através de um processo normal de transmissão.

Sobre o método comparativo utilizado pelos autores, este geralmente é descrito compreendendo duas diferentes questões, a saber, o estabelecimento de uma relação genética de um grupo de línguas e a reconstrução de uma protolíngua da qual aquelas teriam surgido ${ }^{7}$.

Ao utilizar o método comparativo, com o estabelecimento de uma relação genética entre um grupo de línguas, em que a língua é passada de uma geração a outra, Thomason \& Kaufman deixam os pidgins e línguas crioulas de fora, por acreditarem não ser possível estabelecer uma relação com as línguas através das quais os pidgins e línguas crioulas tivessem se desenvolvido ${ }^{8}$.

Para Thomason and Kaufman (1988), a língua é passada de uma geração pai para uma geração filha ou através de um grupo de pares, do imediatamente mais velho ao mais novo. Asseveram ainda que é a história sociolinguística dos falantes, e não a estrutura de suas línguas, o determinante primeiro do resultado do contato linguístico, sendo as considerações linguísticas relevantes, mas secundárias.

Os autores consideram as línguas crioulas resultado de mudança sem transmissão normal. Afirmam não haver necessariamente um pidgin ancestral para cada língua crioula e argumentam que as similaridades poderiam

\footnotetext{
7Essa relação genética entre as línguas seria demonstrada de acordo com os seguintes critérios: (i) o estabelecimento de correspondência fonológica entre palavras do mesmo sentido, ou sentidos relacionados, (ii) a reconstrução de sistemas fonológicos, (iii) o estabelecimento de correspondências gramaticais e (iv) a reconstrução de sistemas gramaticais. Quando mais de duas línguas estão envolvidas, também são adicionados os critérios de (v) construção de um subgrupo de modelo para as línguas e (vi) elaboração de um modelo de diversificação.

${ }^{8}$ Essa afirmação dos autores torna saliente o problema desse tipo de abordagem e reforça a visão de que as línguas crioulas seriam línguas "especiais", que deveriam ser tratadas de modo diferente em relação às demais línguas.
} 
ser explicadas pelas rotas parcialmente paralelas de surgimento. O desenvolvimento de um pidgin para um crioulo não pareceria plausível dado o cenário social do tráfico europeu de escravos.

A hipótese defendida pelos autores é de crioulização abrupta, em que a língua de contato emergente torna-se ao mesmo tempo o idioma principal da comunidade e é aprendido como primeira língua por qualquer criança nascida na nova comunidade multilíngue.

Thomason and Kaufman (1988) salientam, no entanto, que esse não é o único contexto histórico de surgimento e dão como exemplo a Jamaica, onde os escravos eram homens adultos e a população era reabastecida pela importação de novos escravos adultos, não por crianças, sendo a nativização da língua de contato emergente lenta e tardia.

$\mathrm{Na}$ abordagem dos autores, as línguas crioulas surgiriam de uma quebra de transmissão e não possuiriam origem genética. As línguas africanas teriam sido abandonadas e as línguas europeias não teriam sido adquiridas completamente pela população de escravos, o que para eles removeria de todas as línguas crioulas as possibilidades de classificação genética.

\subsection{Crioulização como processo de apropriação linguística: Chaudenson}

Em Creolization of language and culture, de 2001, Robert Chaudenson centrase nas línguas crioulas de base lexical francesa e argumenta, ao longo do livro, contra as abordagens tradicionais da gênese das línguas crioulas 9 .

Distingue dois tipos de pidgins e línguas crioulas (1974:389):

1. O primeiro tipo é chamado de endógeno, desenvolvido pelo contato entre populações indígenas e um grupo imigrante.

2. O segundo tipo é o exógeno, desenvolvido fora do contato entre imigrantes e a população transplantada. Abrange, em geral, variedades insulares. A população nativa tem papel limitado por ter sido rapidamente expulsa ou exterminada pelo processo de colonização.

O autor aponta a crioulização como uma tragédia humana e social caracterizada por três unidades similares:

${ }^{9}$ As línguas crioulas de base lexical francesa, que são o foco da análise de Chaudenson (2001), são faladas nas seguintes regiões: [Região América Caribenha (ACR):] Louisiana, Haiti, Guadalupe e suas dependências, Martinica, Dominica, Santa Lúcia e Guiana Francesa; [Região do Oceano Índico (IOR):] Reunião, Mauritânia, Rodriguez e Seychelles. 
1. unidade de lugar: emergência tipicamente em ilhas;

2. unidade de tempo: desenvolvimento dentro de aproximadamente um século;

3. unidade de ação: evolução em comunidades coloniais de escravos.

Chaudenson coloca como a base primeira do trabalho um exame preciso das condições sócio-históricas de formação e evolução das sociedades coloniais, bem como o modo como essas sociedades eram estruturadas.

Para explicar a formação das sociedades coloniais, o autor a divide em dois períodos: société d'habitation e société de plantation:

Primeira fase: société d'habitation - seria a fase inicial da colonização, em que os brancos eram tão numerosos quanto os negros. Economicamente, foi a fase de colonização e aclimatação e compreendeu o desenvolvimento de uma infraestrutura mínima necessária à agricultura colonial, que poderia definir o período seguinte.

Possui duas características relevantes. A primeira é a evolução demográfica marcada por baixo aumento da população escrava e a segunda característica é socioeconômica, uma vez que as condições da vida diária eram difíceis e colocavam brancos e negros em pé de igualdade ${ }^{10}$.

Segunda fase: société de plantation — a mudança de uma fase a outra não se deu de forma abrupta ou absoluta. Nesta fase houve também uma proletarização dos brancos (os chamados petits blancs) e aumento da população escrava, o que, inevitavelmente, levou a outra forma de trabalho e organização do estilo de vida nas sociedades de habitação; como consequência, essas fazendas tornaram-se o que é geralmente conhecido como plantation.

Terceira fase: o fim da imigração - essa é menos significativa em termos de crioulização da língua e da cultura. Inicia-se quando a ampla imigração da força de trabalho se encerra, o que na maioria dos casos se deu no século XX, coincidindo com um novo sistema de contrato de servidão envolvendo não europeus, o que foi, de diversas formas, um modo disfarçado de escravidão.

Ainda segundo o autor, a abordagem que coloca uma língua crioula como resultado da evolução de um pidgin através de "complexificação das formas" e "expansão dos domínios de uso" é incompatível com os fatos sócio-históricos e sociolinguísticos que caracterizam as fases iniciais das sociedades coloniais. Segundo ele, não há características estruturais

\footnotetext{
${ }^{10} \mathrm{O}$ autor define esse relacionamento como complementar e assimétrico. A assimetria advém do fato de os membros dos dois grupos tratarem-se de modo diferente, embora as condições de vida fossem similares.
} 
que definam as línguas crioulas independentemente das circunstâncias sócio-históricas de sua gênese, nem tampouco considerações estruturais nem sócio-históricas suficientes para caracterizar isoladamente as línguas crioulas.

Chaudenson (2001:162) define em sua hipótese a crioulização como "resultado de um processo sociolinguístico peculiar ao desenvolvimento das sociedades que surgiram na colonização europeia do século XVII". Ademais, o processo é caracterizado pela emergência de novos sistemas autônomos que surgiram da aproximação contínua inicial de um francês dialetal anterior ${ }^{11}$.

O autor admite que essa perspectiva diverge das teorias clássicas de crioulização, em que esta é definida como "nativização" ou "complexificação" de um pidgin. Na perspectiva apresentada por ele, a crioulização resultaria da convergência de fatores como:

1. a provável emergência de uma koiné, já marcada pela reestruturação;

2. a emergência de um continuum de aproximações da língua-alvo em situações comunicativas em que um forte sistema centrípeto é encontrado; e

3. um sistema no processo de autonomização, constituído por estratégias relativamente constantes de apropriação da língua, aproximações "periféricas" de fases anteriores de desenvolvimento.

Todas essas situações apresentam, em graus variados, a característica comum de pouca exposição ou sensibilidade à norma, que seria um fator favorável à reestruturação do sistema. Poder-se-ia considerar a crioulização parte de um caso especial de divergência, na medida em que a reestruturação afeta áreas já variáveis no sistema original. Contudo, ao mesmo tempo, a crioulização seria um processo de mutação linguística radical, já que as mudanças estruturais atingem outras áreas que não seriam, em princípio, afetadas por mudanças associadas exclusivamente a fatores linguísticos internos.

Em suma, o processo de crioulização seria o resultado de três conjuntos de processos que se sobrepõem:

1. "radicalização" e "transmissão" de processos de reestruturação, para os quais as variedades "marginais" do francês ofereceram variantes

\footnotetext{
${ }^{11}$ Esses novos sistemas seriam distinguidos pela aceleração e radicalização do processo de autorregulação, ilustrado pelas variedades "marginais" do francês, especialmente da América do Norte.
} 
e providenciaram a direção. Essas variedades seriam, de alguma forma, os "elos perdidos" na reconstrução de uma evolução que vai do francês à língua crioula, afetando alguns aspectos do sistema, mas não todos;

2. emergência de estruturas não atestadas nas variedades francesas faladas em comunidades onde o francês é transmitido como língua nativa. Essas novas estruturas seriam resultados do reajuste ligado à aprendizagem e ao contato linguístico;

3. evolução interna ligada à própria dinâmica do sistema.

Essa abordagem vê o relacionamento entre as línguas crioulas de base francesa como um "contínuo interlinguístico" e evita o "mito" de uma única língua crioula francesa. As similaridades entre as línguas crioulas poderia ser explicada pela gênese comum do francês e, mais particularmente, pelo processo de autorregulação dessas línguas. Por outro lado, a diferença entre elas poderia ser explicada pela influência de línguas não europeias.

\subsection{Evolução das línguas como especiação: Muf- wene}

Mufwene (2001) e (2008) faz notar que as línguas crioulas são especiais apenas por um acidente e esse acidente é o modo como têm sido abordadas pela linguística. As línguas crioulas são tão naturais como as línguas não crioulas e, ao contrário do que tem sido afirmado pela maioria dos crioulistas, elas não teriam tido uma evolução abrupta, nem teriam sido produtos de quebra de transmissão das línguas das quais elas evoluíram.

O autor apresenta o processo de crioulização como um processo social, não estrutural. Um ponto importante levantado por Mufwene seria o fato de as novas variedades de línguas terem sido originadas da apropriação de variedades não padrão das línguas europeias. E, ainda, as línguas crioulas teriam se desenvolvido pelo mesmo processo de reestruturação que marca a evolução das línguas não crioulas. O contato entre as línguas seria um fator de grande importância nesses desenvolvimentos.

Mufwene aponta que as línguas crioulas, como resultado de contato de línguas e como exemplo perfeito de "línguas mistas", têm sido tratadas como "filhos fora do casamento" e cita Thomason and Kaufman (1988), que afirmam não poderem as línguas crioulas ser classificadas geneticamente pela impossibilidade da utilização do método comparativo. O autor 
argumenta que a base do problema das abordagens como a de Thomason e Kaufman viria da interpretação incorreta da genética Stammbaum, tomada como forma de dar conta da diversificação das línguas.

O problema também viria da suposição básica, em linguística genética, desde o esquema do Stammbaum feito por August Schleicher no século XIX, de que a diversificação normal da língua procede monoparentalmente, como uma reprodução assexuada. Nessa perspectiva, o contato de línguas tem sido especialmente invocado para dar conta de "irregularidades" reveladas pelo método comparativo, não como o gatilho das mudanças "regulares" que levam à especiação.

O autor apresenta algumas abordagens comuns sobre a formação das línguas crioulas que ele considera mitológicas. A primeira delas seria a afirmação de que o desenvolvimento das línguas crioulas teria se dado de maneira abrupta, por obra de crianças, através dos pidgins de seus pais.

A história sugere, no entanto, o desenvolvimento gradual de uma koiné ancestral, falada como vernáculo pela população crioula dos descendentes europeus e não europeus, nas comunidades de habitação que precederam as de plantação. Mufwene também assinala que as plantações não teriam surgido "da noite para o dia", já que a maioria das populações que fundaram as colônias era muito pobre para começar uma plantação. Então, essas populações teriam iniciado com uma pequena fazenda e levado décadas ou, em alguns casos, um século inteiro antes de desenvolver uma plantação considerável.

Outra afirmação comum é que as línguas crioulas refletem a aprendizagem imperfeita das línguas coloniais europeias pelos escravos. Contudo, há outras variedades coloniais que são divergentes da língua falada na "metrópole", como o inglês americano e o português brasileiro, e não são tidas como línguas crioulas.

Um terceiro mito residiria em se afirmar que o fato de as estruturas das línguas crioulas serem tão diferentes de suas "aparentadas" não crioulas seria devido a uma quebra na transmissão de seus lexificadores. Esse é o caso da "hipótese descontinuísta", que não explicaria por que as línguas crioulas retêm grande proporção de seus vocabulários do lexificador, nem por que podemos ligar tantas de suas características estruturais com seus ancestrais europeus não padrão. Não haveria nada na estrutura das línguas crioulas que desse suporte a essa hipótese.

O quarto mito seria a afirmação de que o método comparativo não poderia ser aplicado às línguas crioulas, no sentido de determinar se elas seriam ou não geneticamente relacionadas aos seus "lexificadores". Esse mito seria baseado na comparação incorreta das estruturas das línguas 
crioulas com as variedades padrão das línguas europeias ${ }^{12}$.

Em relação ao pressuposto de que as línguas crioulas seriam línguas peculiares, com tipos únicos de condições ecológicas que as colocariam à parte de outros casos de especiação de língua, Mufwene argumenta que algumas questões devem ser resolvidas. Uma delas seria a questão que surge da associação da emergência das línguas crioulas com as colônias de plantação, especialmente de cana-de-açúcar. Se essa associação é verdadeira para o Caribe, não o é para o Brasil.

Algumas colônias, como as Antilhas Holandesas e Cabo Verde, produziram variedades identificadas como línguas crioulas, embora dificilmente tenham desenvolvido qualquer agricultura industrial notável. Elas serviram primeiramente como posto de comércio e depósito de escravos. Diante disso, levanta-se o questionamento se haveria alguma justificativa para associar o desenvolvimento de línguas crioulas às grandes plantações e tratar a emergência do português popular brasileiro como uma exceção à regra.

No que concerne ao mito da "descrioulização", Mufwene afirma que não há evidências diacrônicas convincentes para esse processo e mostra também que o grande problema da hipótese de semicrioulização, como reversa à hipótese de descrioulização, encontra-se na dificuldade em determinar quais são realmente as "características crioulas" ou o que seria um suposto "crioulo prototípico".

O processo "crioulização", para o autor, seria a extensão de um processo de reestruturação já iniciado nos "lexificadores" relevantes. Não haveria uma medida exata que pudesse ser utilizada para identificar se a reestruturação procedeu-se somente na metade, ou em partes, pois a realidade de cada língua crioula, mesmo as que evoluíram de um mesmo lexificador, difere da de outra, do mesmo modo que as línguas românicas, germânicas ou bantas e seus respectivos familiares compartilham apenas partes da estrutura.

Sobre o fato de as línguas crioulas terem surgidos de pidgins, o autor salienta que um simples olhar na distribuição geográfica já sugere que essa ancestralidade seria questionável. A maioria dos pidgins está concentrada na costa atlântica da África e em ilhas do Pacífico, enquanto que a maioria das línguas crioulas que evoluíram de línguas europeias está concentrada no Atlântico, ilhas do Oceano Índico e na costa atlântica das Américas.

No tocante ao papel das crianças na evolução das línguas crioulas,

\footnotetext{
${ }^{12} \mathrm{O}$ autor observa que, nesse caso, as línguas crioulas podem realmente revelar a artificialidade do método comparativo, se baseado em dados constituídos de registros escritos. Afirma ainda que as línguas crioulas seriam, juntamente com suas parentes coloniais, o último resultado linguístico da dispersão indo-europeia.
} 
sua função seria mais de agentes de normalização. As crianças crioulas contribuíram da mesma forma que crianças em toda parte contribuem para a mudança e divergência da variedade de seus pais, até mesmo porque, nos períodos prósperos das colônias, a população cresceu mais por importação do que por nascimento.

A chave para entender por que as línguas crioulas são diferentes de suas aparentadas não crioulas que evoluíram de variedades similares das línguas europeias é o fato de que a "aquisição da linguagem" é um processo de reconstrução sensível às variantes em competição. As línguas crioulas desenvolveram-se pela reestruturação gradual de estruturas de uma primeira koiné colonial das línguas europeias relevantes, em direção aos seus basiletos, que na verdade são os últimos a terem evoluído.

\section{4·5.1 Evolução de línguas e línguas crioulas}

A divergência entre as variedades crioulas e não crioulas que emergiram nas colônias seria, então, uma consequência da segregação racial, que reduziu o alcance social e, portanto, a interação verbal entre europeus e não europeus nas plantações.

Mufwene utiliza o termo princípio fundador juntamente com população fundadora para explicar como as características estruturais das línguas crioulas foram predeterminadas, em larga medida, pelas características dos vernáculos falados pela população que fundou as colônias. O desenvolvimento das línguas crioulas seria um conjunto de casos de adaptações naturais de língua às mudanças das condições ecológicas ${ }^{13}$.

Sumarizando, a história da colonização europeia sugere que nem todos os cidadãos ou pessoas falavam nativamente as línguas que lexificaram as diferentes línguas crioulas, e que o contato nas sociedades de habitação que precederam as plantações teria sido regular. Depois que as colônias mudaram para a fase de economia de agricultura, com plantações de canade-açúcar e campos de arroz, a população escrava passou a constituir de oitenta a noventa por cento da população. Esse período foi marcado pelo aumento geral de importações de escravos, o que levou à "maioria negra" e à concomitante institucionalização da segregação racial. Essa rápida taxa de substituição em que cada vez menos falantes eram suficientemente fluentes teria servido como modelo linguístico para os que chegavam depois.

Outro fator importante que daria conta da evolução linguística seria a afirmação de que uma língua não é transmitida indiscriminadamente. Ela

\footnotetext{
${ }^{13} \mathrm{O}$ princípio fundador não é uma hipótese de desenvolvimentos das línguas crioulas tal como as hipóteses universalistas, substratistas ou superstratistas. Seria, sim, um dos vários princípios que devem ser considerados para dar conta do desenvolvimento delas.
} 
seria desconstruída e recriada para adequar-se cada vez mais às necessidades comunicativas de cada falante. Essa transmissão pode ser caracterizada como um processo fragmentado e nenhum falante recria perfeitamente um idioleto particular nem o conjunto de idioletos que ele visa. Haveria também o fato de que nem a desconstrução nem a recriação, ao menos na aquisição natural da língua, são atividades conscientes.

\subsection{O estatuto das línguas crioulas}

Neste momento do trabalho, assumiremos em consonância com Mufwene (2001), (2008) que o que torna possível a classificação de uma língua como crioula são as condições sócio-históricas de seu surgimento. Na visão do autor o processo de crioulização configura-se como social, não estrutural.

Lang (1994:90) assinala que: "uma língua não é crioula pela sua 'essência' (que nem sei o que é), nem pelo seu funcionamento, mas pela sua origem."

Enfatizamos também, em consonância com Chaudenson (2001:162), que o processo de crioulização seria "o resultado de um processo sociolinguístico peculiar ao desenvolvimento das sociedades que surgiram na colonização europeia do século XVII."

Nessa esteira de pensamento podemos afirmar que, em última instância, o próprio termo "línguas crioulas" deve ser repensado, dado que não há elementos linguísticos que as diferenciem das demais línguas naturais.

Diante disso, como consequência, optamos por nos referir à língua, no presente trabalho, não como crioulo de Cabo Verde, mas simplesmente, caboverdiano.

Em nossa perspectiva, o debate apresentado neste capítulo, a saber, sobre a formação das chamadas línguas crioulas, deve inserir-se em um contexto mais amplo sobre o contato de línguas, ao invés de tentar apontar como se deu sua origem, ou ainda tentar encontrar características que seriam exclusivas a essas línguas - uma vez que vários estudos apontam que essas características exclusivas não existiriam - , mas no sentido de entender como se dá o processo do contato linguístico e quais mudanças linguísticas podem advir desse contato.

Tal opção permitiria, por exemplo, ajudar a esclarecer as mudanças ocorridas em línguas como o português brasileiro (PB). Este seguiu um caminho diferente do português europeu (PE) devido, segundo alguns estudiosos, ao contato com diferentes línguas africanas e indígenas. Logo, ao aprofundar os estudos sobre as "línguas crioulas de base portuguesa", poderíamos elucidar alguns aspectos das mudanças seguidas por essas 
línguas, como um modo de entender o caminho evolutivo - se é que podemos chamar assim - de línguas que tiveram o mesmo componente inicial, a saber, o português europeu do século XVI, mas com resultados diferentes. É importante ressaltar que não se devem deixar de lado as características sócio-históricas da formação de cada uma delas.

Em outras palavras, sugerimos que línguas como o caboverdiano, sãotomense e principense ajudariam a entender certas mudanças ocorridas no português brasileiro, dada algumas semelhanças existentes entre elas no que concerne ao contexto de formação. Levando em conta o fato de que o português que foi levado tanto para o Brasil quanto para Cabo Verde ou ainda para São Tomé e Príncipe foi o português europeu do século XVI e ainda que existiu uma situação de contato entre esse português e outras línguas - africanas no caso de Cabo Verde e São Tomé e Príncipe e línguas africanas e indígenas no caso do Brasil - nesses diferentes países, faria mais sentido aproximar essas diferentes línguas (português brasileiro, caboverdiano, são-tomense e principense) entre si, do que compará-las ao português europeu, por exemplo, sobretudo ao português europeu contemporâneo.

O português europeu contemporâneo sofreu uma mudança em relação ao português que foi levado às diferentes colônias no século XVI como, por exemplo, a expressão do aspecto progressivo, logo, se há alguma relação entre o português brasileiro ou o caboverdiano com o português europeu, seria com o português quinhentista.

É importante trazer à tona também a proposta de Petter (2008). A autora mostra que, através da história do contato e dos aspectos linguísticos comuns entre o "português moçambicano", o "português angolano" e o "português brasileiro", é possível levantar a hipótese de um continuum entre essas variedades que derivam de uma história comum, a saber, a expansão da língua portuguesa num contexto de colonização. Esse contínuo resultaria de uma "mistura" de línguas locais com uma língua dominadora comum. A autora observa ainda que:

Desse contexto decorre um estatuto linguístico específico para a língua portuguesa em cada território onde ela é falada, que não impede, no entanto, a existência de um continuum entre as variedades linguísticas selecionadas.

(Petter, 2008:12)

Em suma, e em termos gerais, a ideia seria a de que toda mudança linguística seria engatilhada através do contato e isso colocaria em "pé 
de igualdade" todas as línguas naturais. O que as diferenciaria seria os aspectos sociais e históricos, ou seja, a ecologia particular a cada situação de contato de línguas.

\subsection{Considerações}

Neste capítulo apresentamos um panorama de como as chamadas "línguas crioulas" têm sido tratadas por diferentes estudiosos ao longo dos anos. Apresentamos os diferentes argumentos utilizados na tentativa de estabelecer elementos que seriam exclusivos às línguas crioulas.

Por fim, apresentamos a visão dos autores Chaudenson (2001) e Mufwene (2001), (2008), que trazem uma abordagem diferente, não conferindo mais um estatuto linguístico singular a essas línguas.

Na esteira desses dois autores e da proposta apresentada na seção 4.6, enfatizamos o fato de que o caboverdiano deve ser estudado com base nos fatos da própria língua, e não em uma comparação com o português europeu devido a uma alegada ancestralidade, ou ainda devido a uma "ruptura" em relação ao português europeu.

Nesse sentido seria mais fácil explicar alguns fatos do caboverdiano (ou entendê-los de maneira mais adequada) ao olhar outras línguas que surgiram em condições semelhantes do que tentar enquadrá-los em análises baseadas no português europeu. 
CAPÍTULO 5

\section{O sintagma nominal do caboverdiano}

\subsection{Introdução}

No presente capítulo trataremos das características gerais do sintagma nominal do caboverdiano. Exploraremos a questão dos nomes nus observando uma das estratégias de expressão de genericidade na língua, bem como as interpretações definida e indefinida dos nomes nus.

Em outras palavras, partindo do fato de que os nomes em caboverdiano, em sua maioria, não precisam ser acompanhados de determinantes, tentaremos verificar o que pode favorecer determinadas leituras ou interpretações do nome em detrimento de outras.

\subsection{Características gerais}

Em caboverdiano, os nomes, em geral, não são acompanhados de qualquer determinante. A língua possui, no entanto, a partícula un(s), que pode, entre outras coisas, veicular indefinitude. A presença de un(s), contudo, não é obrigatória para que um dado NP possa ser interpretado como indefinido. É importante notar que há, conforme registros do World Atlas of Language Structures Online (WALS), pelo menos, quarenta e cinco línguas no mundo — não denominadas crioulas - em que os nomes não precisam ser acompanhados de qualquer determinante para que possam ser interpretados como indefinidos. Entre elas estão o lango, o núbio, o obolo e o duka, no 
continente africano; o remo, o santali e o byansi, na Índia; e o nuaulu, na Indonésia, entre outras.

Uma das análises mais amplas realizadas sobre o sintagma nominal do caboverdiano foi empreendida por Baptista (2007). A autora define nomes nus ${ }^{1}$ como nomes sem determinante aberto, que podem ou não carregar a marca de plural. Afirma que há, em caboverdiano, dois tipos de determinantes que marcam número, mas não gênero: o artigo indefinido $u n$ e sua contraparte plural uns. No campo da definitude, kel e sua contraparte plural kes poderiam exercer, segundo a análise da autora, um papel de determinante definido, embora sua função primeira seja de demonstrativo (pg. 62 e 63).

Em caboverdiano, $u n(s)$, tanto em sua forma singular, quanto em sua forma plural, pode desempenhar várias funções na língua. Pode atuar como numeral, determinante indefinido ou, ainda, como quantificador. O NP introduzido por un pode ser interpretado como específico ou não específico. A contraparte singular, quando acompanha entidades abstratas, comporta-se como quantificador, já a contraparte plural, por outro lado, comportar-se-ia como um quantificador quando acompanhada de entidades contáveis (Baptista, 2007:65 a 67).

Segundo a autora, embora uma das funções de un(s) seja introduzir um novo referente, sua presença não é requerida para que dado NP seja interpretado como informação nova (pg. 66). Tanto nomes sem a presença de $u n(s)$ quanto nomes acompanhados por ele podem ter as mesmas interpretações. Em outras palavras, nomes com ou sem a presença de un(s) são passíveis de ser interpretados como indefinidos específicos, não específicos ou, ainda, como nomes quantificados ${ }^{2}$.

Para fatos como esse, Dryer (2011a) aponta que nas línguas em que há apenas o determinante indefinido, como o tauya da Papua-Nova Guiné, a presença desse determinante, na grande maioria das vezes, não é obrigatória. Assinala também que, nessas mesmas línguas, um NP sem artigo pode ser interpretado igualmente como definido ou como indefinido.

\footnotetext{
${ }^{1}$ Utilizaremos a nomenclatura nomes nus, ao longo desta dissertação, para nos referir aos nomes sem a presença de determinantes. Essa denominação serve à literatura em geral para contrapor nomes com a presença de determinantes a nomes sem essa presença, considerando que nomes acompanhados de determinantes sejam a forma mais usual. Contudo, pelo menos em caboverdiano, os nomes nus seriam a forma "padrão" na língua. A presença de determinantes, por outro lado, é guiada por estratégias específicas.

${ }^{2}$ Embora existam algumas questões a serem esclarecidas quanto ao comportamento de un no caboverdiano, principalmente em relação ao possível comportamento como quantificador tanto de sua contraparte singular, quanto plural, não nos aprofundaremos na análise de suas diferentes funções. Adotaremos, portanto, as análises realizadas por Baptista (2007).
} 
Baptista questiona então se é possível prever, categoricamente, quando un ou $\mathrm{kel}^{3}$ devem ser usados e quando $\varnothing$ deve aparecer. Admite, porém, que não está apta a responder a essa questão por ora, mas que, em sua análise, realiza uma tentativa de definir as condições favoráveis à ocorrência dos nomes nus.

$\mathrm{Na}$ análise da autora, os nomes nus do caboverdiano apresentam alto grau de variabilidade interpretativa, o que os torna passíveis de serem interpretados como genérico, definido específico (singular ou plural), definido não específico singular, indefinido específico (singular ou plural), indefinido não específico (singular e plural). A interpretação relevante, de acordo com ela, seria capturada através de pistas no próprio texto ou fora dele (contextuais).

Além desses fatos, para a autora a ausência de um determinante ou de marcador plural não implica que o nome possua denotação massiva. Os dados (1) e (2) são apresentados para exemplificar, respectivamente, a leitura atômica e não atômica de nomes como djentis ("pessoas"):

(1) Ta ben djentis di stranjeiru ki ta ben, HAB vir pessoas PREP estrangeiro PRON.CONJ.PREP HAB vir ta ben buska-m pa'N konta-l storia HAB vir buscar-1SG.OBJ PREP' ${ }_{1}$ SG.OBJ contar-3SG.OBJ história di $(\ldots)$

PREP

Tem gente que vem de fora do país, vem me buscar para eu lhe contar (para ele) história de (...)

(Baptista, 2007:74)

(2) Ta ben djentis di stranjeiru ki ta ben, HAB vir pessoas PREP estrangeiro PRON.CONJ.PREP HAB vir ta ben buska-m pa'N konta-s storia HAB vir buscar-1SG.OBJ PREP' ${ }_{1}$ SG.OBJ contar-3PL.OBJ história di $(\ldots)$ PREP

Tem gente que vem de fora do pais, vem me buscar para eu lhes contar (para eles) história de (...)

(Baptista, 2007:74)

Ainda segundo a autora, a marcação do status de definitude do nome seria vista como desnecessária se a consciência coletiva ou a unicidade

\footnotetext{
${ }^{3} \mathrm{Na}$ análise da autora, $\mathrm{kel} \mathrm{seria} \mathrm{um} \mathrm{demonstrativo} \mathrm{quando} \mathrm{não} \mathrm{há} \mathrm{menção} \mathrm{prévia} \mathrm{do}$ referente, mas um determinante anafórico quando há menção prévia. Detalharemos essa questão no capítulo 6.
} 
da entidade a tornasse familiar aos interlocutores. Seria, por exemplo, o caso de fenômenos naturais como txuba ("chuva"), ou entidades únicas, como sol. Outra razão para a ocorrência de nomes nus, conforme Baptista $(2007: 74)$, seria o fato de haver indivíduos e outros elementos que são parte da experiência e conhecimento comum dos interlocutores ${ }^{4}$.

$\mathrm{Na}$ análise de Baptista, os nomes nus definidos singulares tendem a ser encontrados em posição de sujeito, enquanto os indefinidos singulares aparecem na posição de objeto (2007:77). A autora salienta, porém, que se trata apenas de tendências da língua e que é possível encontrar indefinidos específicos e genéricos (3) em posição de sujeito ${ }^{5}$.

(3) Amigu ka ta faze keli.

amigo NEG HAB fazer DEM

Amigo não faz isso.

(Baptista, 2007:77)

Ademais, na perspectiva de Baptista, outros elementos na sentença, tais como tempo e aspecto, podem direcionar o ouvinte à interpretação correta. A oposição genérico versus episódico também influencia na interpretação relevante (2007:77).

Ao apresentar as condições e os cenários subjacentes à ocorrência dos nomes nus em caboverdiano, Baptista destaca que os apresentados por ela seriam apenas tendências e não refletem todo o conjunto de condições sob as quais os nomes nus podem ocorrer.

\subsection{Os nomes nus no caboverdiano}

Antes de tentar prever quando um ou outro elemento deve aparecer juntamente com o nome, tentaremos explorar, mesmo que de modo tangencial, as estratégias de interpretação dos nomes nus.

Dado que os nomes em caboverdiano prescindem da presença de determinantes, verificaremos quais seriam então as estratégias que possibilitam ou favorecem as diferentes interpretações. Para tanto, trataremos de dois fatos separadamente: a leitura genérica das sentenças e as interpretações definida e indefinida dos nomes.

\footnotetext{
${ }^{4}$ Em nossas análises, no entanto, a definitude, ou o status de definido do nome não precisa estar associado a um item lexical, há outras estratégias, além das apontadas por Baptista (2007), que possibilitam a interpretação definida do nome.

${ }^{5} \mathrm{~A}$ interpretação definida e indefinida do nome, em caboverdiano, não estaria tão atrelada à posição sintática, mas sim à estratégias semânticas de interpretação, conforme apresentaremos ao longo deste capítulo.
} 


\section{5·3.1 Sobre os nomes nus: discussão teórica}

Na tradição semântica, um dos trabalhos mais citados dentro da literatura sobre os nomes nus é o artigo A Unified Analysis of the English Bare Plural, de 1977, escrito por Greg Carlson. Nesse artigo, o autor divide a leitura dos plurais nus ${ }^{6}$ em dois tipos básicos: genérico (4) e existencial (5):

(4) Cavalos são mamíferos.

(5) Eu vi transeuntes recusar ajuda ao ferido.

(Müller, 2003:68)

A respeito dos tipos básicos de leitura dos plurais nus feita por Carlson, poder-se-ia descrever a leitura genérica como incorporando um quantificador do tipo universal (6); a leitura existencial, por sua vez, seria descrita como incorporando um quantificador equivalente ao plural do artigo indefinido $(7)$ :

(6) Todos os cavalos são mamíferos.

(7) Eu vi alguns transeuntes recusar ajuda ao ferido.

(Müller, 2003:68)

Na perspectiva de Carlson, os plurais nus comportam-se tanto sintática quanto semanticamente como nomes próprios. Um exemplo disso seria seu comportamento em contextos opacos. Observe-se a sentença (8):

(8) Maria quer falar com um pesquisador de baleias.

A sentença (8) gera duas leituras possíveis. Na primeira, representada em (9a), o pesquisador de baleias existe e é intenção da Maria falar com ele; já na segunda leitura, em (9b), falar com um pesquisador de baleias está embutido no desejo da Maria e esse pesquisador não precisa sequer existir.

(9) a. Existe alguém que é pesquisador de baleias e Maria deseja falar com este alguém.

\footnotetext{
${ }^{6}$ Carlson (1977), em Müller (2003), chama de bare plurals ("plurais nus") os sintagmas nominais não precedidos de determinantes. No português brasileiro, nem sempre a forma plural sem artigo será a mais natural para expressar o sentido dos plurais nus do inglês (Müller, 2003).
} 
b. Maria deseja falar com qualquer pessoa que seja pesquisador de baleias.

Compare-se (8) com os dados (10) e (11), retirados de Müller (2003:69). A sentença (10) não permitiria uma leitura em que economistas progressistas existam necessariamente, tal como a leitura em (9b). Tanto em (10) quanto em (11) não há leitura ambígua, e é esse o comportamento que Carlson atribui aos plurais nus do inglês. Em síntese, os nomes nus não gerariam leitura ambígua em contextos opacos, o que seria equivalente ao comportamento dos nomes próprios no mesmo contexto.

(10) Maria deseja falar com economistas progressistas.

(11) Maria deseja falar com Carlos.

Deve-se observar que, em alguns casos de contextos transparentes, a mesma ambiguidade gerada em (8) pode ser produzida por um modalizador deôntico como dever (12).

(12) Maria deve falar com um pesquisador de baleias.

A análise sobre a denotação dos plurais nus do inglês apresentada por Carlson (1977) não pode, entretanto, ser aplicada a todas as línguas. No português brasileiro, singulares nus também podem veicular uma leitura genérica, como se pode observar em (13). Todavia, o singular nu não é uma condição necessária para se obter a leitura genérica, argumento exemplificado em (14).

Müller (2003:163) aponta que as sentenças (13) e (14), embora suscitem leitura genérica, são interpretadas com base em dois processos distintos. A sentença (13), com o singular nu, diz: "geralmente, se alguém é brasileiro, gosta de futebol". A generalização envolve a sentença inteira, ou seja, o conteúdo como um todo expressa uma generalização. Em (14), por sua vez, "ter quatro patas é uma propriedade que se aplica à classe dos gatos", refere-se a toda a classe de entidades. A genericidade, nesse caso, é uma propriedade do sintagma nominal e não da sentença.

(13) Brasileiro gosta de futebol.

(14) O gato tem quatro patas.

Para Müller (2003), no PB, as sentenças genericamente quantificadas preferem o singular nu - (13) -, ao passo que a expressão de referência à espécie pode ser denotada pelo sintagma nominal definido - (14). 
Outrossim, de acordo com a análise de Müller (2003:165), o definido genérico tem sua referência determinada, em grande parte, pelo conhecimento partilhado e não tanto por seu conteúdo lexical.

Diante da ambiguidade de muitas expressões nominais, que trazem uma leitura genérica e uma leitura específica, e também de muitas sentenças com leitura episódica e leitura de quantificação genérica, Müller (2003:168) apresenta alguns testes para verificar se determinada expressão nominal ou sentença tem leitura genérica ou não.

A autora argumenta que sentenças genericamente quantificadas podem ser parafraseadas, de maneira aproximada, com advérbios sentenciais como necessariamente, geralmente ou tipicamente. O teste em (16b) mostra que essa não é uma sentença genericamente quantificada, uma vez que o uso do advérbio sentencial geralmente a torna agramatical7.

(15) a. Gatos perseguem ratos.

b. Gatos tipicamente perseguem ratos.

(16) a. Gatos acabam de chegar na sala.

b. ${ }^{\star}$ Gatos geralmente acabam de chegar na sala.

(17) a. Político fala muito.

b. Geralmente, político fala muito.

(Müller, 2004:6)

(18) *Político está falando muito agora na sala 235.

Para Müller (2004:11), no português brasileiro, os nomes nus singulares são agramaticais em posição de sujeito de sentenças episódica (18) e (20).

(19) Menino brinca de herói.

(20) *Menino estava brincando de herói agorinha há pouco.

(Müller, 2004:11)

Na visão da autora, no PB os nomes nus em posição de sujeito teriam sempre interpretação genérica. Não seria possível uma interpretação específica ou existencial para esses casos, mesmo em sentenças episódicas - ver (21).

(21) Judeu está fazendo jejum hoje.

(Müller, 2004:11)

Leitura existencial: \#Tem judeu que está fazendo jejum hoje.

7Exemplos (15), (16) e (18) foram adaptados. 
Leitura genérica: A maioria dos judeus está fazendo jejum hoje.

Entretanto, em algumas situações, o PB parece admitir interpretações episódicas associadas a nominais nus em posição de sujeito. É o caso, por exemplo, do uso (em alguns dialetos, ao menos) de nomes comuns muito familiares, que se comportam quase como nomes próprios, como pode ser observado em (22), de sentenças com verbo topicalizado como em (23) ou, em alguns dialetos, de sentenças com o objeto topicalizado, conforme (24).

(22) Mãe passou lá em casa na semana passada.

(23) Caiu água que não acabava mais ontem à tarde.

(24) O outro que morava na praia, carro matou na estrada.

$($ Oliveira and Miranda, 2011)

É preciso acrescentar, contudo, que tais exemplos são menos frequentes, pelo menos na região sudeste do Brasil, que os explorados por Müller (2004).

\subsubsection{A noção de pressuposição}

Antes de analisarmos as diferentes leituras em caboverdiano, é necessário discorrer um pouco sobre a noção de pressuposição que estará presente ao longo de nossas análises.

Cançado (2005) faz notar que a pressuposição além de relacionar-se com o sentido das expressões lexicais contidas nas sentenças, também se refere a um conhecimento prévio, extralinguístico, compartilhado entre o falante e o ouvinte e seria uma noção semântico-pragmática.

A autora observa ainda, em consonância com Ilari and Geraldi (1987: 76 ) citados por Cançado (2005), que as pressuposições não fazem parte do conteúdo assertado, no entanto, a estrutura linguística é que nos oferece os elementos para derivar o conteúdo pressuposto, daí ser uma noção semântico-pragmática.

Chierchia and McConnell-Ginet (1996) observam que, grosso modo, a ideia seria a de que a pressuposição de uma sentença $S$ restringe ou

\footnotetext{
${ }^{8} \mathrm{O}$ dado (24) foi retirado de Oliveira and Miranda (2011). O referido trabalho foi fruto do Projeto-Piloto IPHAN/USP "Levantamento etnolinguístico de comunidades afrobrasileiras de Minas Gerais e Pará", coordenado pelas professoras $\operatorname{Dr}^{a}$ s Margarida Petter e Márcia Oliveira da Faculdade de Filosofia, Letras e Ciências Humanas da USP. Esse projeto insere-se no quadro do Inventário Nacional da Diversidade Linguística (INDL), que visou inventariar a diversidade linguística brasileira.
} 
limita a classe de contextos $C$ relativos aos quais $S$ pode ser enunciada de maneira feliz ou adequada. A pressuposição de $S$ deveria ser satisfeita por um contexto $c$ a fim de que $S$ possa ser assertada, ou seja, para que um enunciado de $S$ seja satisfatório naquele dado contexto.

A sentença $\left(25^{a}\right)$ pressupõe a sentença $\left(25^{b}\right)$ e o conteúdo de $\left(25^{a}\right)$ implica que ( 25 b) é tomado como certo. Nesse caso, presumir que Joana tomava vinho no café da manhã é necessário para que a sentença faça sentido ao ouvinte, mesmo se esse fato não for previamente conhecido.

(25) a. Joana parou de tomar vinho no café da manhã.

b. Joana tomava vinho no café da manhã.

O conteúdo pressuposto de uma dada sentença se mantêm inalterado mesmo quando essa sentença for negada (26b), ou colocada em uma forma interrogativa (26c), ou ainda como uma condicional antecedendo uma outra sentença $(26 \mathrm{~d})$.

(26) a. José emprestou o carro dele para Pedro.

b. Não é verdade que José emprestou o carro dele para Pedro.

c. José emprestou o carro dele para Pedro?

d. Se José emprestou o carro dele para Pedro, Pedro deve estar contente.

No caso da sequência de sentenças em (26), o fato de o carro pertencer a José permanece inalterado e esse conteúdo compartilhado pelas sentenças é chamado de pressuposição (Cançado, 2005:32).

\subsubsection{Leitura genérica no caboverdiano}

Nem as análises sobre os plurais nus do inglês, nem tampouco as análises sobre os nomes nus do português brasileiro, podem ser aplicadas ao caboverdiano.

Na subseção 5.3.1, vimos que, no português brasileiro, nomes nus são geralmente agramaticais em posição de sujeito de sentenças episódicas. Além do mais, quando em posição de sujeito, tendem a receber interpretação genérica.

Em caboverdiano, por outro lado, nomes nus são gramaticais em posição de sujeito de sentenças episódicas (27) e ainda podem ter leitura existencial.

(27) Mudjer $\varnothing$ gosta d'el, $\varnothing$ fika ku el ala. Mulher PFV gostar PREP' ${ }_{3} \mathrm{SG}$ PFV ficar PREP ${ }_{3} \mathrm{SG}$ lá

(A) mulher gostava dele e ficou com ele lá. 
Existe um $\mathrm{x}$, tal que $\mathrm{x}$ é mulher e $\mathrm{x}$ gostava dele.

(Baptista, 2007:77)

Observamos o fato de tanto o inglês quanto o português brasileiro não possuírem nomes nus como a forma padrão do sintagma nominal. Este fato por si só produziria importante diferença em relação ao comportamento sintático e semântico dos nomes nus em caboverdiano. Dessarte, os nomes do caboverdiano devem ser analisados de modo distinto aos do português brasileiro, ou aos de qualquer outra língua em que os nomes geralmente sejam acompanhados de determinantes9.

Baptista (2007) não explora a interpretação genérica das sentenças em caboverdiano, contudo, apresenta um insight importante para nossas análises.

João ta bebe garafa di vinhu

João HAB beber garrada PREP vinho

João bebe garrafa de vinho.

(Baptista, 2007:76)

Para a autora, em (28), garafa di vinhu pode ser interpretado como definido específico (29a), como indefinido não específico (29b) e, ainda, como indefinido específico (29c), conforme explicitado:

(29) a. João bebe as garrafas de vinho (armazenadas na adega).

b. João bebe garrafas de vinho (a noite toda).

c. João bebe garrafas de vinho (que datam de 1985).

A interpretação precisa de garrafas de vinho, de acordo com Baptista, varia de acordo com o sentido da marca aspectual de habitualidade $t a$, contexto geral ou a ancoragem de advérbios e modificadores.

A nosso ver, em (28), há realmente uma interpretação ambígua de 'garafa di vinhu' que deverá ser explicitada pelo contexto, no caso do dado em questão. Observamos, no entanto, que não é a marca aspectual de habitualidade que tornará a interpretação do nome saliente, nesse caso, a marca de habitualidade favoreceria uma interpretação genérica da sentença,

${ }^{9}$ Diferente do que fora apontado por Baptista (2007:80), não atribuímos a ocorrência dos nomes nus no caboverdiano a uma tendência à economia. A autora questiona a ocorrência do uso de determinantes em caboverdiano em contraste com a utilização de determinantes em línguas como o francês e o inglês, atribuindo a utilização dos nomes nus em caboverdiano a uma propensão à economia. De acordo com a autora, quando o falante julga que há informação situacional suficiente, eles tendem a respeitar o princípio do mínimo esforço. Conforme apontamos, não partilhamos dessa análise. 
que se configura, a nosso ver, como uma estratégia separada da estratégia interpretação do nome como definido e indefinido. E será essa a questão abordada nessa e nas próximas seções.

Sobre as sentenças genéricas, é importante reiterar que não descrevem eventos particulares mas sim regularidades, além de denotar espécies. De acordo com nossas análises, uma das estratégias que favoreceriam a leitura genérica das sentenças é a presença da marca aspectual verbal de habitualidade - $t a$.

A sentença (30) significa que a cachupa ${ }^{10}$ leva, em geral, três horas para ficar pronta. Em (31), a interpretação da habitualidade é bastante clara.

(30) Katxupa ta dura tres óra pa sta prontu.

Cachupa HAB durar três hora PREP estar pronta

(A) Cachupa leva três horas para ficar pronta.

(Inverno and Swolkien, 2003)

(31) Amigu ka ta faze keli. amigo NEG HAB fazer DEM

Amigo não faz isso.

(Baptista, 2007:77)

A sentença em (32), com leitura genérica e também com marca de aspecto habitual, diz: "Em geral, eu conto papelão e recebo dois contos por isso". Trata-se de uma sentença genericamente quantificada. A genericidade, nesse caso, envolve toda a predicação.

(32) $\mathrm{N}$ ta konta papelon, $\mathrm{N}$ ta recebê dôs kontu.

$1 \mathrm{SG}$ HAB contar papelão $1 \mathrm{SG} \mathrm{HAB}$ receber dois conto

Eu conto papelão e recebo dois contos.

Em (33) observa-se uma interpretação semelhante: "Em geral, eu trabalho na estação de chuvas".

(33) Mas ami, $\mathrm{N}$ ta trabadja azagua.

ADV 1SG.T 1SG HAB trabalhar estação-de-chuva.

Mas eu, eu trabalho na estação de chuvas.

(Baptista, 2007:67)

Em (34), a despeito da presença do quantificador todo, observa-se a leitura genérica favorecida pela marca aspectual de habitualidade.

\footnotetext{
${ }^{10}$ Prato típico de Cabo Verde feito à base de milho.
} 
(34) Tudu mundo ta flaba ki mudjer sta

Todo mundo HAB falar.PST PRON.CONJ.PREP mulher estar pa ten fidju ka ta karega sacu sal, ka ta karega PREP ter filho NEG HAB carregar saco sal NEG HAB carregar simentu.

cimento

Todo mundo dizia que mulher que está para ter filho não carrega saco de sal, não carrega saco de cimento.

A leitura genérica pode ser veiculada por verbos estativos, conforme dados $(35)$ e $(36)^{11}$ :

(35) Tradison di Badiu, ten txeu kuza: kotxi midju, kotxi Tradição PREP badio ter muito coisa esmaga milho esmaga na pilon, bu kotxi, bu bentia, bu tra farelu, bu po PREP pilão 2SG esmaga, 2SG separa, 2SG tirar farelo, 2SG por katxupa riba, i bu fase masa, fase tenteren, $\mathrm{ku}$ pexi cachupa em.cima, e 2SG fazer massa, fazer tenterén, com peixe o $\mathrm{ku}$ leti. ou com leite Tradição de Badio tem muitas coisas: mói milho, mói no pilão, você mói, separa, tira o farelo, coloca a cachupa em cima, e faz a massa, faz tenterén com peixe ou com leite. ${ }^{12}$

(Baptista, 2007:71)

Kela k'e nos kumida tradisional, Esta PRON.CONJ.PREP'ser 1 PL.POSS comida tradicional, fixon, $\mathrm{ku}$ xeren, $\mathrm{ku}$ tenterén. feijão, com xerém, com tenterén Esta que é nossa comida tradicional: feijão com xerém, com tenterén.

(Baptista, 2007:71)

Diante do exposto, o caboverdiano parece comportar-se de modo distinto ao português brasileiro quanto a expressão de genericidade. Müller (2003 : 154) observa que no português brasileiro, assim como no inglês, as sentenças genéricas "parecem não possuir nenhuma característica formal, quer em sua estrutura sintática, quer na marcação morfológica de seus constituintes, que as distingua superficialmente das outras sentenças da

\footnotetext{
${ }^{11}$ Baptista (2007) não explora a interpretação genérica das sentenças. Observamos, contudo, em adição à análise da autora, que o que veicula a leitura genérica das sentenças (35) e (36) são os verbos estativos.

${ }^{12}$ Tenterén: comida tradicional, para ou xerém de milho torrado.
} 
língua."

Em suma, no que concerne à leitura genérica das sentenças no caboverdiano, podemos conjecturar, conforme os dados, que a marca aspectual de habitualidade apresenta-se como uma das estratégias que poderiam torná-la saliente. Os verbos estativos também podem veicular uma leitura genérica. Além disso, a expressão da genericidade em caboverdiano não estaria necessariamente atrelada à presença de qualquer determinante, mesmo em sintagmas nominais de referência a espécies ${ }^{13}$.

\section{5·3.4 Interpretação definida}

Nas línguas que possuem artigo definido, a interpretação definida do sintagma nominal é comumente veiculada quando da presença desse artigo junto ao nome.

Uma das propriedades semânticas que distinguem o artigo definido de outros determinantes é a pressuposição de unicidade da extensão modificada pelo artigo definido, enquanto os demais determinantes não geram tal pressuposição.

C. Lyons (1999) observa que a unicidade assinala que há somente uma entidade que satisfaz determinada descrição. Essa unicidade, contudo, não é absoluta, mas entendida como relativa a um contexto particular.

Em (37) a pressuposição de unicidade do nome modificado pelo artigo definido se mantém, mesmo que, nesse caso específico, ele se refira a uma classe.

O gato tem quatro patas.

Consoante as nossas análises, em caboverdiano - assim como em outras línguas que não possuem artigo definido - a interpretação definida do nome não prescinde da pressuposição de unicidade, mesmo sem um artigo definido. Por conseguinte, essa pressuposição seria uma das estratégias para a captura de tal interpretação.

Aqui, corroboramos a afirmação de Baptista (2007:70) de que os determinantes podem estar ausentes se a informação suficiente quanto ao status de (in)definitude for provido por outras estratégias, sejam sintáticas, semânticas ou ainda relativas ao tempo verbal.

\footnotetext{
${ }^{13}$ Observamos, no entanto, que não estamos discutindo aqui outras estratégias que poderiam favorecer leituras genéricas como, por exemplo, a presença do quantificador $t u d u$, tal como evidenciado no exemplo (34).
} 
A autora observa que a marcação do status de definitude, ou referencial, do nome é vista como desnecessária se o conhecimento partilhado entre os falantes ou ainda a unicidade da entidade a torna familiar aos interlocutores (pg. 74). Entretanto observamos, novamente, que o status de definitude não precisa estar associado a um item lexical.

Diante disso e levando em conta o fato de a grande maioria dos nomes em caboverdiano prescindirem da presença de determinantes, exploraremos a noção de pressuposição de unicidade da entidade, vista como uma das estratégias para a captura da interpretação definida do nome em caboverdiano. Essa pressuposição de unicidade pode ser marcada por estratégias sintáticas ou semânticas.

Vale ressaltar que, em nossas análises, as estratégias de leitura genérica da sentença e de interpretação do nome não estão necessariamente relacionadas. Em outras palavras e diferente do que fora apontado por Baptista (2007:77), a leitura genérica da sentença não implica, necessariamente, que não se pode ter uma interpretação definida do nome.

Nas sentenças (38) e (39), a estratégia sintática utilizada para gerar a pressuposição de unicidade é a retomada do nome através do pronome de terceira pessoa " $e$ " (ele).

(38) saku simentu e ta bem lá Somada káru ta saco cimento $3 \mathrm{SG} \mathrm{HAB}$ vir ADV Assomada carro HAB trazedu di lá. trazer.PST PREP ADV

O saco de cimento, ele vem lá da Assomada, o(s) carro(s) que trouxe(traziam) de lá.

(39) Inton, maridu $\mathrm{N} \varnothing$ vivê ku'el uns ténpu, má maridu Então marido 1 SG PFV viver PREP' ${ }_{3} S G$ DET tempo mas marido ben móri.

vem morrer.

Então, (meu) marido, eu vivi com ele um tempo, mas ele já morreu. ${ }^{14}$

(Rodrigues, 2007)

Em (40) observa-se, igualmente, a pressuposição de unicidade. Aqui, a entidade (Câmara dos Deputados, ou dos Vereadores) faz parte do conhecimento partilhado (common ground) entre os informantes, num comportamento semelhante ao dos nomes próprios.

\footnotetext{
${ }^{14}$ Mesmo levando em conta que em sociedades monogâmicas tem-se, pelo menos perante a lei, apenas um único marido, ainda consideramos a utilização da retomada do nome através da terceira pessoa do singular, como uma estratégia sintática que gera a pressuposição de unicidade da entidade.
} 
(40) Ma $\mathrm{N}$ ta trabadja gosi $\mathrm{ku}$ kanbra.

Mas 1SG HAB trabalhar agora PREP câmara

Mas eu trabalho agora com a Câmara (prefeitura).

(Baptista, 2007:72)

Em (41), não obstante a marca aspectual verbal de habitualidade e, consequentemente, da leitura genérica, observa-se que a entidade é única. Ou seja, é a língua caboverdiana que se ouve todos os dias em Cabo Verde e faz parte do common ground dos falantes.

(41) Pamodi kriolu nu ta obi tudu óra.

Porque crioulo 1 PL HAB ouvir tudo hora

Porque (o) crioulo a gente ouve toda hora.

Müller (2003:158) observa, para o português brasileiro, que o fato de haver uma sentença genérica não implica necessariamente que a generalização recaia sobre o sujeito ou ainda que o sujeito possua necessariamente uma interpretação de espécie. A nosso ver, essa análise pode ser aplicada também ao caboverdiano.

O nome auto-káru no caso de (42), motiva uma interpretação definida ${ }^{15}$. Aqui observamos que o auto-káru esperado era único, aquele que iria para Vila Nova.

(42) $\mathrm{N} \varnothing$ péra auto-káru, $\mathrm{N}$ bai lá Vila Nova. 1SG PFV esperar auto-carro 1 SG ir ADV Vila Nova Eu esperei o ônibus, eu fui lá para Vila Nova.

Importa ainda destacar que, tanto em (38) quanto em (42), a interpretação é definida e não específica, ou seja, embora pressuponham unicidade, o nome não aponta para um ser em particular no mundo.

Em (43), também há a interpretação definida, é a cabeça do marido que está doente. Aqui, a interpretação gerada é a definida específica, ou seja, aponta para uma entidade específica no mundo ${ }^{16}$.

(43) Nha maridu ten cinku anu ku kabesa mariada. 1SG.POSS marido ter cinco ano PREP cabeça doente

\footnotetext{
${ }^{15}$ Não se observa, em (42), a presença da marca de aspecto habitual antes do verbo. Como apresentado na subseção 3.2.2, a ausência de qualquer marca aspectual antes de verbos não estativos indica que estes estão no passado. Tem-se aí uma sentença episódica, em que a verdade ou a falsidade dependem de um lugar e tempo específicos.

${ }^{16}$ A marcação do aspecto verbal dá-se de maneira distinta em verbos estativos, como "ter". Logo, em tais casos, essa não seria uma noção relevante para a captura das diferentes leituras das sentenças.
} 
Meu marido tem cinco anos que está doente da cabeça.

Exploramos aqui uma das noções semânticas que possibilitam a interpretação definida dos nomes em caboverdiano: a pressuposição de unicidade, que pode ser veiculada na língua através de estratégias sintáticas e semânticas.

Observamos ainda que a interpretação do nome não está, necessariamente, ligada à posição sintática, conforme dados (42) e (41) em que os nomes não são sujeitos das sentenças e, ainda sim, possuem interpretação definida. E, além disso, que as sentenças genéricas não impedem a interpretação definida dos nomes. Em outros termos, diferente do que fora apontado por Baptista (2007:77), a interpretação dos nomes parece estar mais associada às noções semânticas e não tanto à função sintática.

\section{5•3.5 Interpretação indefinida}

Diferentemente da leitura definida, na indefinitude parece haver certa neutralidade quanto à unicidade do referente. Para C. Lyons (1999), no NP indefinido o falante parece estar ciente do que é referido, mas o ouvinte não.

Em (44) observamos a ausência de marca aspectual verbal, o que ancora esse evento em um momento passado. Diante disso, podemos considerar (44) como uma sentença episódica, o que, de partida, produziria uma leitura não genérica. No que concerne a interpretação dos nomes, aqui poderia haver mais de um médico, enfermeiro e servente arrumando a informante. Não há requerimento, nem tampouco estratégia sintática ou semântica, que indique ser apenas um de cada.

Aqui nossa análise difere novamente da de Baptista (2007). Segundo a autora, em caboverdiano, um nome nu é interpretado como referencial (definido ou indefinido) se a sentença for episódica (pg. 77). No entanto, esse não parece ser o caso de (44).

(44) Lá dentu du hospital $\varnothing$ rumanu ami. Dotor, ADV dentro PREP hospital PFV arrumando 1SG.T doutor nfermér(u), (serventi), tudu rumanu ami. enfermeiro servente tudo arrumando 1 SG.T. Lá dentro do hospital, eles me arrumaram. Doutor(es), enfermeiro(s), servente(s), todos me arrumaram.

Em (45), (46) e (47), do mesmo modo que em (44), além de as sentenças serem episódicas, não há requerimento ou qualquer estratégia - sintática ou semântica — que indique serem as entidades únicas. 
(45) Ami dja fasi dosi pa bendi (...) ami dja bendi 1SG.T ADV fazer.PST doce PREP vender 1 1SG.T ADV vender paozinhu... pão.GRAU Eu já fiz doce para vender (...) Já vendi pãozinho...

(46) $\mathrm{Li}$ era só rabidante ki moraba. ADV ser.PST só vendedor PRON.CONJ.PREP morar.PST Aqui, era só vendedor (ambulante) que morava.

(47) Ami dja $\varnothing$ kavu kova simentéra. 1SG.T ADV PFV cavar cova sementeira Eu já cavei cova na sementeira.

Sumarizando, em caboverdiano, a interpretação indefinida dos nomes parece ser favorecida pela não pressuposição de unicidade, ou seja, através da neutralidade quanto à unicidade da extensão. Salientamos, porém, que essa seria uma das estratégias possíveis para a captura da interpretação indefinida do nome.

\section{$5 \cdot 4$ Considerações}

Apresentamos, de maneira sucinta, alguns dos comportamentos dos nomes nus do caboverdiano. Aqui, temos em síntese duas noções relevantes: a interpretação dos nomes e as diferentes leituras das sentenças.

Sobre as leituras das sentenças, observamos que uma das estratégias que possibilitam a leitura genérica parece ser a marca aspectual de habitualidade $-t a-$, que aponta para regularidades. A ausência dessa marca, por outro lado, geraria outras leituras. Embora contrapondo aqui as leituras genéricas e não genéricas, ressaltamos que também há outras marcas aspectuais verbais, conforme apresentado na subseção 3.2.2, que podem veicular leituras diferentes.

As interpretações definida e indefinida dos nomes, por seu turno, seriam favorecidas em sentenças episódicas. Esta não chega a ser, porém, uma condição necessária para tais interpretações.

Em caboverdiano, mesmo sem um determinante definido, a pressuposição de unicidade do nome é veiculada por diferentes estratégias - seja pela retomada anafórica do nome, seja por fazer parte do conhecimento partilhado entre os falantes - e essa pressuposição seria uma das noções semânticas que possibilitam a interpretação definida dos nomes na língua. A ausência dessa pressuposição, por sua vez, levaria à interpretação indefinida dos nomes. 
Observamos, por fim, que ao analisar os nomes nus como a forma default dos nomes em caboverdiano, as análises poderiam ser simplificadas na medida em que o questionamento não recairia mais sobre o motivo pelo qual os determinantes são omitidos na língua, mas sim o porquê e em quais situações eles ocorrem, uma vez que diferentes estudos já apontaram que a ocorrência de nomes acompanhados de determinantes é bem menos frequente do que a ocorrência de nomes nus. Diante disso, o foco das análises recairia nas diferentes estratégias (sintáticas, semânticas ou pragmáticas) de interpretação dos nomes (nus) em caboverdiano. 


\section{CAPÍTULO 6}

\section{Kel e a definitude}

\subsection{Introdução}

Alguns estudos sobre o sintagma nominal do caboverdiano apresentam kel e sua forma plural kes como possíveis artigos definidos, ou afirmam que eles exercem, por vezes, o papel de artigos definidos na língua (Baptista (1997), (2002) e (2007), Alexandre and Soares (2004), entre outros). Os autores que se debruçaram sobre o tema, contudo, parecem não precisar o que licencia tal uso.

Para Brüser et al. (2001) e Veiga (2002), o caboverdiano não possui artigo definido. Veiga admite, todavia, que há algumas manifestações do artigo definido que se confundem com o demonstrativo. Exploraremos essa questão mais adiante.

Importante observar que tanto a classe do artigo definido quanto a dos demonstrativos podem expressar definitude. Para C. Lyons (1999), nas línguas em que não há o artigo definido, a definitude seria expressa, em alguns casos, por um demonstrativo. Esse fato poderia levar, em nossa opinião, alguns autores a afirmar que kel exerce o papel de artigo definido em caboverdiano.

Outrossim, em alguns estudos sobre o sintagma nominal do caboverdiano, parece haver um equívoco quanto à distinção entre as noções de informação dada e familiaridade ou identificabilidade, o que acaba levando a análises e interpretações dúbias sobre o comportamento de kel.

Nas próximas seções, empreenderemos uma discussão teórica sobre 
definitude, dado que tanto o artigo definido quanto o demonstrativo expressam essa noção. Esta discussão teórica visa, igualmente, esclarecer alguns questionamentos sobre as duas classes para que possamos, por fim, apresentar - e entender - o comportamento de kel dentro do sintagma nominal do caboverdiano.

\subsection{A noção de definitude em Heim (1982)}

Para Heim (1982), a característica da descritividade, ou seja, a presença ou não de conteúdo descritivo, seria o que distingue sintagmas nominais como "um gato" e "o gato" de pronomes como "ele" ${ }^{1}$. A definitude, por outro lado, distinguiria sintagmas nominais como "o gato" e "ele" de "um gato". Em outras palavras, a definitude coloca NPs indefinidos de um lado e descrições definidas ${ }^{2}$ e pronomes de outro.

A autora apresenta a definitude como um conjunto de três propriedades:

i. definidos não estão sujeitos à regra de interpretação de Indexação de Operador;

ii. definidos não estão sujeitos à Condição de Novidade; e

iii. definidos pressupõem seu conteúdo descritivo.

Heim questiona então quais seriam as condições semânticas e pragmáticas que determinam a escolha (do falante) entre um NP definido e um indefinido. Para tratar dessa questão, apresenta Christophersen (1939) como o primeiro a desenvolver uma teoria influente, a "Teoria da Familiaridade da Definitude". Nessa perspectiva, a função essencial da definitude seria assinalar que o referente pretendido de um sintagma nominal já é familiar à audiência no corrente estágio da conversação.

Em seu trabalho, Heim (1982) dissocia familiaridade de referência e, por outro lado, liga a distinção novo-familiar a algo mais abstrato que referentes. Afirma, então, que novidade e familiaridade, conceitos tomados tradicionalmente como pragmáticos, são propriedades puramente formais

\footnotetext{
${ }^{1}$ Heim (1982) explora uma análise alternativa daquelas que analisavam as descrições definidas e indefinidas como quantificadores e os pronomes definidos como variáveis. $\mathrm{Na}$ análise da autora, todos os indefinidos e definidos são quantificadores livres, ou seja, possuem uma variável livre essencial e o predicado descritivo.

${ }^{2}$ As descrições definidas, na visão da autora, pressupõem existência no sentido de ser um elemento do domínio de indivíduos. Quanto a saber se isso implica a existência no mundo real ou se pode referir-se ou quantificar possíveis indivíduos que não existem, Heim (1982) deixa em aberto.
} 
dentro das formas lógicas; ou seja, um NP será "familiar" ou "novo" em um texto se estiver, ou não, coindexado a outro NP que o precede nesse mesmo texto. Ademais, definidos novos poderiam ocorrer quando um pronome fosse usado deiticamente.

O conceito de "novidade", na perspectiva da Condição de Novidade apresentada pela autora, seria, dessa forma, puramente uma questão de coindexação na forma lógica. A novidade em relação à forma lógica seria uma condição necessária, mas não suficiente. Para Heim, o NP pode ser novo em relação à forma lógica do texto em que é enunciado, e ainda ser familiar ao "arquivo"3.

Na visão da autora, nem a Condição de Novidade-Familiaridade nem a de Conteúdo Descritivo podem ser deduzidas uma da outra. No entanto, há uma relação próxima entre as duas. Ainda de acordo com Heim (1982), pode-se dizer, intuitivamente, que ambas as condições relacionamse com "familiaridade" em algum sentido, pois a Condição de NovidadeFamiliaridade requer que o definido esteja associado a um NP já estabelecido e a Condição de Conteúdo Descritivo, por seu turno, requer que o conteúdo descritivo do definido já seja estabelecido, isto é, "familiar"4.

A autora admite, no entanto, que há muitos usos de definidos, em especial de descrições definidas, que não cabem na teoria apresentada por ela. Ao olhar a taxonomia dos usos do artigo definido, não seria possível para a presente perspectiva teórica dar conta da maioria deles.

Para tratar dos diferentes usos do artigo definido a autora apresenta Hawkins (1978) que cita, pelo menos, oito. Desses, somente dois obedecem à Condição de Novidade-Familiaridade de Heim, a saber: o uso anafórico e o chamado "uso de situação visível", ou seja, que requer a saliência perceptual do referente. Alguns dos usos que não se enquadrariam na Condição de Novidade-Familiaridade são exemplificados a seguir:

- Situação de uso imediato - uma pessoa está andando na calçada e outra diz:

(1) Cuidado, o cachorro $i$ vai te morder.

- Uso em situação ampla (larger situation use) - uma pessoa diz ao telefone:

3Dentro dessa perspectiva teórica, "arquivo" pode ser visto como common ground, ou seja, o conhecimento prévio dos participantes, a informação que os interlocutores têm em comum no discurso.

${ }^{4}$ As duas condições são apresentadas como dois aspectos de uma condição mais inclusiva denominada, por Heim (1982), de Condição de Novidade-Familiaridade Estendida. 
(2) $\mathrm{O} \mathrm{sol}_{i}$ está brilhando.

- Uso anafórico associativo:

(3) João leu [um livro sobre Schubert $]_{i}$ e escreveu para o autor ${ }_{j}$.

Para os usos que não obedecem à condição a presentada por Heim (1982), ela argumenta haver um mecanismo de acomodação ou ajustamento, mas não abandona a Condição de Novidade-Familiaridade. Esse mecanismo de acomodação seria engatilhado a partir da violação de alguma condição de felicidade, o que levaria a adicionar informação suficiente para evitar essa violação.

Heim (1982) observa, no entanto, que a questão de acomodação em relação aos definidos é um pouco mais complexa, não se trata de uma simples adição de informação que restaura a condição de felicidade. Quando uma nova informação é introduzida sob acomodação, esta deve ser ligada, através de referência cruzada, a alguma já existente. A referência cruzada formaria uma "ponte" conectando o novo referente do discurso a uma rede de referentes já estabelecida. Isso torna-se, de acordo com a autora, particularmente evidente nos chamados usos anafórico-associativos ${ }^{5}$.

\subsection{A definitude segundo C. Lyons (1999)}

Ao explorar a questão da definitude, C. Lyons (1999) observa o fato de existirem, em algumas línguas, elementos que parecem ter o papel exclusivo de indicar a definitude ou indefinitude do sintagma nominal ${ }^{6}$.

À semelhança de Heim (1982), o autor explora a noção de familiaridade e identificabilidade. Segundo ele, no sintagma nominal indefinido, somente o falante parece estar ciente do que é referido, enquanto que, no definido, essa consciência é compartilhada pelos interlocutores. Nesse sentido, o artigo definido assinalaria que a entidade é "familiar", enquanto o indefinido seria usado quando o falante não tivesse a intenção de compartilhar essa familiaridade.

C. Lyons argumenta, contudo, que a noção de familiaridade é um tanto problemática para a distinção definido-indefinido. Exemplos disso seriam

\footnotetext{
5 Para a autora, na maioria dos casos de uso imediato e de uso em "situação ampla", a informação nova adicionada não estaria ligada, talvez, a uma informação já existente, mas diretamente à situação de enunciação.

${ }^{6}$ Esses elementos podem possuir a forma de um item lexical, como os artigos definido e indefinido do inglês, ou de um afixo, como, por exemplo, em árabe, com o prefixo definido al- e o sufixo indefinido $-n$.
} 
6.3 A definitude segundo C. Lyons (1999)

os usos associativos, situacionais, entre outros - apresentados na seção anterior.

O autor argumenta ainda que alguns linguistas preferem ver a definitude relacionada à identificabilidade 7 . O artigo, ele mesmo, não identifica o referente, pois se trata de uma palavra gramatical, sem conteúdo lexical descritivo. O máximo que pode fazer é convidar o ouvinte a explorar pistas no contexto linguístico ou extralinguístico. $\mathrm{O}$ artigo pode estar relacionado à identificabilidade, mas não à identificação. Essa hipótese, porém, não exclui a familiaridade, pois é ela que habilita o ouvinte a identificar o referente.

Para C. Lyons (1999), a identificabilidade parece dar conta de modo mais adequado da definitude que a familiaridade. Todavia, há casos em que a primeira não seria possível. Os usos associativos, em geral, são problemáticos para a identificabilidade. Funcionam porque o ouvinte está apto a associar um NP definido a alguma entidade que ele espera encontrar ou associar àquela situação determinada ${ }^{8}$.

C. Lyons (1999) acrescenta que a distinção mais fundamental a ser feita é entre as línguas que possuem artigos e as que não possuem. Segundo o autor, todas as línguas possuem demonstrativos e pronomes pessoais que são, talvez, inerentemente definidos.

A marcação de definitude simples seria, na visão do autor, uma característica areal. Uma grande concentração de línguas que marcam definitude simples encontra-se na Europa ocidental e no Mediterrâneo e, também, em partes do mundo onde línguas dessas regiões foram transplantadas pela colonização.

Das línguas que distinguem definido e indefinido simples haveria, então, três modos pelos quais essa distinção pode ser expressa:

a. somente pela marca de definitude;

b. somente pela marca de indefinitude;

c. pelas duas marcas.

Haveria, ainda, segundo o autor, línguas em que o artigo definido pode ser omitido quando as condições situacionais — ou do discurso — para a definitude são aplicadas, como, por exemplo, o hausá.

${ }^{7}$ A ideia seria que o uso do artigo definido direciona o ouvinte ao referente do NP, assinalando que o ouvinte estaria em condições de identificá-lo.

${ }^{8}$ A noção de inclusividade também é importante. A definitude com plurais e massivos não envolve unicidade, mas inclusividade: a referência é a totalidade dos objetos ou massas no contexto. 
Em hausá, o sufixo definido é usado, em geral, anáforica e associativamente. Nessa língua, o aparecimento ou omissão do artigo não pode ser completamente previsto. Esse aparecimento ou omissão, contudo, é amplamente determinado pela acessibilidade do referente. Em outras palavras, um nome nu é usado quando se julga que o referente é de fácil acesso, enquanto a marca de definido é utilizada quando um esforço maior parece ser requerido. Caso a tarefa de identificar o referente seja ainda maior, um demonstrativo é usado (Jagger, 1985).

C. Lyons (1999) salienta que, na maioria das línguas, é possível referir-se a algo previamente mencionado utilizando um demonstrativo. Pode ser, no entanto, que não esteja claro se um determinante especializado em uso anafórico é artigo ou demonstrativo.

Ainda sobre os demonstrativos, o sistema em que o falante é o ponto de referência primário seria, para o autor, básico e encontrado em quase todas as línguas. As línguas variam, todavia, quanto ao princípio organizacional pautado na pessoa ou na distância do falante. Os demonstrativos são quase invariavelmente acentuados, e para C. Lyons esse seria o maior ponto de contraste com os artigos definidos.

Por fim, há as oposições tópico-comentário, tema-rema, dado-novo e pressuposição-foco que figuram, proeminentemente, na organização da informação ${ }^{9}$. Muitas dessas noções, aliás, podem ser intercambiáveis.

Uma informação dada é diferente de familiaridade ou identificabilidade. Um NP definido pode representar uma informação nova, em que o referente não tenha sido introduzido previamente, ou que não seja saliente na consciência dos participantes. Um NP indefinido, por sua vez, pode ser dado, ou seja, seu conteúdo descritivo pode ter ocorrido previamente no discurso ou, ainda, ele pode ser parte do conhecimento comum dos falantes. A identificabilidade que caracteriza muitos definidos geralmente é uma questão de ocorrência prévia no discurso e a familiaridade é, em geral, suficiente para prover a saliência mental necessária para algo que é dado.

C. Lyons (1999) assinala que a definitude parece, empiricamente, ser um fenômeno unificado. Duas características seriam proeminentes mas não, nas palavras do autor, completamente adequadas: a identificabilidade, que favoreceria particularmente o uso referencial, sobretudo quando o referente é uma entidade física e localizável (visualmente) no contexto; e a inclusividade, que favoreceria os usos não referenciais.

${ }^{9} \mathrm{Na}$ teoria pragmática, definitude tem seu lugar na área denominada "estrutura do discurso" ou "estrutura da informação", ou ainda "estrutura temática". Essa área preocupase com os modos em que sentenças "agrupam” a mensagem transmitida, de forma a expressar o relacionamento entre a mensagem e o contexto, ou o background. 


\subsection{Artigo definido versus demonstrativo}

Alexiadou et al. (2007) apresentam, além da noção de artigo definido de C. Lyons $(1999)^{10}$, as seguintes concepções do artigo definido:

- um subordinador que assinala o status argumental a um NP complemento (Abney, 1987); (Stowell, 1989), (1991); (Szabolcsi, 1994:81);

- um carregador "natural" de referencialidade (Loebel, 1989); (Longobardi, 1994) e (1996);

- um morfema puramente gramatical cujo papel primário é assinalar caso ao NP complemento (Giusti, 1993), (1997) e (2002).

Sobre os demonstrativos, Alexiadou et al. (2007:95) argumentam que a diferença entre eles e o artigo definido é que os primeiros são uma categoria universal, isto é, diferentemente do artigo definido, os demonstrativos são encontrados em todas as línguas. As autoras destacam ainda que os demonstrativos admitem uso duplo: são usados ou intransitivamente, sem um NP complemento como, por exemplo, no inglês "this" e no alemão "diese", ou transitivamente, com um NP complemento, como o inglês "this book" e o alemão "dieses Buch". Esse último, em geral, é referido como o uso adjetival dos demonstrativos.

As duas classes expressam definitude, porém, há algumas peculiaridades que as distinguem entre si. Alexiadou et al. (2007:98) assinalam que, embora ambos sejam definidos, somente o artigo definido pode referir-se a termos de classe:

(4) a. O dodo está extinto.

b. \#Este dodo está extinto.

Além disso, de acordo com as autoras, os demonstrativos não trazem leitura genérica, denotam entidades sem descrevê-las, além de serem diretamente referenciais. $\mathrm{O}$ uso do demonstrativo envolve um contraste entre referentes.

Se, por um lado, o artigo definido e os demonstrativos compartilham os componentes semânticos da identificabilidade e da referencialidade, por outro, o elemento dêitico os coloca em conjuntos diferentes.

\footnotetext{
${ }^{10}$ C. Lyons (1999) concebe o artigo definido como uma categoria gramatical que, em algumas línguas, gramaticaliza a noção semântico-pragmática de definitude, apesar de a própria definitude ser considerada pelo autor como categoria gramatical.
} 
O componente dêitico dos demonstrativos ajuda a localizar o referente em algum ponto no contexto não linguístico. A característica dêitica é, em geral, interpretada de dois modos: ou codificam a oposição [+ / - proximal], com o falante como ponto direto de ancoragem; ou, alternativamente, a característica dêitica é feita contingentemente na categoria gramatical de pessoa e denota associação ou proximidade do falante, ou ainda um conjunto de indivíduos que inclui o falante (Alexiadou et al., 2007:100).

Na visão de Roberts (2002), a característica diferenciadora dos demonstrativos seria a pressuposição de uma demonstração que os acompanha. $\mathrm{O}$ autor considera os demonstrativos um tipo de NP definido, assim como os pronomes e as descrições definidas.

Em defesa de seu argumento, o autor observa que os demonstrativos podem ser utilizados para fazer referência a constituintes de um discurso; podem ainda ser acompanhados por demonstração, mas também podem ocorrer sem a indicação gestual do referente e, nesse caso, na maioria das vezes, possuem um antecedente. Alguns demonstrativos podem ter a interpretação de variável presa, além de poderem ter escopo restrito sobre modais ou outros operadores. Em síntese, para Roberts (2002), os NPs demonstrativos apresentam uma gama de comportamentos que são típicos de descrições definidas e pronomes.

\subsection{Comportamento de kel no caboverdiano}

Quanto às argumentações sobre a existência de determinante definido em caboverdiano, Alexandre and Soares (2004) afirmam que a língua possui um artigo definido em desenvolvimento, no caso, kel. Veiga (2002:67) argumenta que o artigo definido, como classe gramatical, não existe em caboverdiano. Assinala também que o emprego de kel como artigo definido é muito raro. Quint (2000) declara que essa partícula possui amplitude semântica tão vasta que, por vezes, pode cobrir a função do artigo românico ou português. Para Brüser et al. (2001) contudo, em caboverdiano, não há artigo definido.

É importante além disso observar que a grande maioria dos autores afirma não poder o uso dessa partícula ser considerado sistemático, tampouco previsível, nem na função de artigo definido nem na de demonstrativo.

O WALS (World Atlas of Language Structures Online) assinala sessenta e nove línguas ao redor do mundo que se utilizam do demonstrativo para veicular definitude. Dentre elas citamos o ewe, o akan, o musgu e o xhosa no continente africano; o newar, o lahu, o tibetano e o tamang no continente 
asiático; o indonésio, o ma'anyan e o bajau na Indonésia; e o chashibo e o uraruna no Peru.

Neste trabalho conjecturamos que, em caboverdiano, assim como em um número de outras línguas do mundo, o emprego do demonstrativo nesse caso, $\mathrm{kel}$ - tem por função também veicular definitude, embora esse uso não seja considerado frequente na língua.

Desde já frisamos que não encontramos, pelo menos nos registros do WALS, qualquer língua que possua como único artigo o indefinido e que ao mesmo tempo empregue o demonstrativo para veicular definitude.

\subsubsection{Análises de kel}

Baptista (2007:69) advoga que kel é demonstrativo quando não há menção prévia do referente, mas um determinante anafórico quando há menção prévia. Ressaltamos, porém, que os demonstrativos também podem retomar um referente (conforme Roberts (2002) e C. Lyons (1999)). Por conseguinte, esse não poderia ser um argumento suficiente para conjecturar que kel desempenha o papel de artigo definido em caboverdiano.

Nomes modificados por $\mathrm{kel}$, do mesmo modo que os nomes modificados por un, podem ser interpretados como específicos ou não específicos e parecem ocorrer, segundo Baptista, em variação livre com a marca $\varnothing$ (pg. 69).

A respeito das características de kel, observamos que:

- ele pode ocorrer tanto com nomes específicos quanto com não específicos;

- pode funcionar como anafórico correferencial, embora o referente possa também ser retomado na ausência de qualquer determinante;

- a menos que seja sucedido pelo pronome ki em orações relativas restritivas, não pode, sozinho, realizar anáfora por ligação;

- parece não poder ser utilizado para apresentar informações novas.

Note-se que o fato de $\mathrm{kel}$ poder ocorrer com nomes não específicos e não ter leitura genérica já poderia distanciá-lo da classe dos artigos definidos.

Apesar de kel realmente parecer expressar definitude no caboverdiano, sua presença, assim como a presença de qualquer outro determinante, não é necessária para que os nomes em caboverdiano sejam definidos, conforme apresentado na subseção 5.3.4 do capítulo anterior. À semelhança do kriyol da Guiné-Bissau, em caboverdiano, especificadores vazios são 
frequentemente encontrados onde artigos definidos são previstos para o português.

Lucchesi (1994) advoga que, em caboverdiano, não há nenhum dispositivo especial para marcar a distinção entre específico e não específico. Afirma também que o uso da partícula tida como artigo definido $(\mathrm{kel})$ junto aos NPs específicos pressupostos é bastante irregular. Na visão do autor, o uso dessa partícula seria determinado, então, mais por fatores discursivos ou estilísticos do que por alguma necessidade de se marcar determinada referencialidade do nome. Ele destaca ainda que, além de o uso de kel ser irregular, a partícula também pode ocorrer com nomes não específicos, como se vê em (5):

(5) alves un pesoa ta labãta denti di sink'ora o às-vezes DET pessoa HAB levantar dentro PREP cinco'horas ou seys ora di palmañã, pa buska kel pala o kel seis horas PREP manhã, PREP buscar DEM palha ou DEM leña.

lenha.

Às vezes, uma pessoa levanta por volta das cinco ou seis horas da manhã para buscar palha ou lenha.

(Lucchesi, 1994)

Em sua tese de doutorado, Baptista (1997:15) aponta kel como demonstrativo usado para marcar definitude quando refere-se a entidades já conhecidas. Observa, porém, que há situações em que serve puramente como marcador de definitude, explicitando, na visão da autora, uma perda da função demonstrativa.

Já em Baptista (2002:24), a autora assinala que a função primária de kel seria a de um demonstrativo, embora, de acordo com ela, possa desempenhar o papel de determinante definido na língua. Para defender a dupla função de kel em caboverdiano, Baptista argumenta que a língua tem seguido o caminho evolutivo comum aos determinantes em várias línguas no mundo, em que artigos definidos são desenvolvidos de demonstrativos ${ }^{11}$.

Segundo a autora, por regra, o caboverdiano não marca um NP como definido por meio de determinante aberto. O uso de kel como determinante definido seria para referir-se a uma entidade conhecida no discurso, mas não necessariamente que já tenha sido introduzida previamente.

Na seção 6.4, vimos que o demonstrativo, além de retomar um referente,

\footnotetext{
${ }^{11}$ Salientamos, porém, que explicações diacrônicas podem não ser as mais adequadas em análises que apresentam recorte sincrônico, como é o caso do estudo da autora em questão.
} 
pode ser utilizado para referir-se a uma entidade familiar no discurso, mesmo sem esta entidade ter sido introduzida anteriormente. Essa não seria uma função exclusiva do artigo definido.

Em (6), há a retomada do nome bolsa através de kel e essa retomada dá-se por meio de uma relativa explicativa.

$\mathrm{N}$ ka ten nha bolsa, kel bolsa ki
1SG NEG ter 1 SG.POSS bolsa DEM bolsa PRON.CONJ.PREP
dá por tudu kusa neli, un bês n ka tinha.
PREP por tudo coisa PREP DET vez 1 SG NEG ter.PASS
Eu não tinha minha bolsa, aquela bolsa que dá para pôr um monte de
coisa nela, antigamente eu não tinha. ${ }^{12}$

Dryer (2011b) observa que, em muitas línguas pelo mundo, é possível usar o demonstrativo anaforicamente. Todavia, as línguas diferem, de maneira considerável, na frequência com que o demonstrativo é utilizado desse modo. Também de acordo com ele, considera-se que um demonstrativo tenha uso de artigo definido se os exemplos em que os nomes são retomados anaforicamente por esse demonstrativo "sejam maiores do que no caso do inglês", embora, a nosso ver, esse critério não pareça ser muito claro.

Ao que parece, se aplicássemos essa definição ao caboverdiano, caso os exemplos de retomadas anafóricas do nome com $\mathrm{kel} \mathrm{fossem} \mathrm{mais} \mathrm{numerosos}$ do que a retomada do nome sem a presença dele, poderíamos considerar que ele desempenha o papel de artigo definido. Como vimos de acordo com nossas análises e, ainda, de acordo com Baptista (2007), este não é o caso.

Em algumas línguas em que o demostrativo pode ser usado como artigo definido, quando cumpre a função de artigo definido, em geral, ele ocorre em posição diferente dentro do sintagma nominal. Em swahili, por exemplo, o demonstrativo segue o nome quando usado demonstrativamente, mas o precede quando usado como artigo definido. A situação inversa é atestada em ute, shambala e pa'a (C. Lyons, 1999).

Diferentemente do que apontamos em Miranda et al. (2010), $\mathrm{kel}$ pode introduzir um referente no discurso, mas isso não significa que seja uma entidade desconhecida dos interlocutores. É importante sublinhar aqui a distinção entre informação dada e nova versus familiaridade e identificabilidade, realizada por C. Lyons (1999) e apresentada em 6.3.

Caso a entidade faça parte do conhecimento partilhado entre os interlocutores, ela pode ser introduzida no discurso por kel. Nesse caso, o que está em jogo é a familiaridade, que, de acordo com C. Lyons (1999), é

\footnotetext{
${ }^{12}$ Em caboverdiano a expressão un bês significa "antigamente, nos tempos antigos".
} 
suficiente para prover a saliência mental necessária a algo que é dado. Em suma, "informação dada" não significa obrigatoriamente que tenha sido previamente introduzida no discurso.

Nos dados (7) e (8), temos a presença de kel juntamente com um NP em sua primeira ocorrência no discurso:

(7) Inton, ten kel fésta, primeru fésta ki nu ta Então, ter DEM festa, primeiro festa PRON.CONJ.PREP ${ }_{1}$ PL HAB ten li ...

ter ali ...

Então, tem aquela festa, a primeira festa que nós temos ali...

(Rodrigues, 2007)

(8) Kel otu dia dimingu, ta ledu na kel otu kasa.

DEM outro dia domingo HAB ler.PST PREP DET outro casa

Naquele domingo, [nós] líamos naquela outra casa.

(Baptista, 2002:28)

Em (9), o referente também é introduzido no discurso por kel. No entanto, o referente aí torna-se familiar através da explicação que se segue: não é qualquer mulher, é a mulher que mora próximo, ao lado. Em outras palavras, o referente faz parte do common ground.

$$
\begin{aligned}
& \text { "N ta bai ku bo", kel mudjer ki mora } \\
& \text { 1SG HAB ir PREP 2SG DEM mulher PRON.CONJ.PREP morar } \\
& \text { pegadu } \varnothing \text { fla-m. } \\
& \text { pegado PFV falar-PRON.OBL } \\
& \text { "Eu vou com você", disse aquela mulher que mora ao lado. }
\end{aligned}
$$

Outro argumento utilizado para defender o status de kel como artigo definido é a sua aparente impossibilidade de ocorrer juntamente com possessivos (Alexandre and Soares, 2004) ${ }^{13}$.

Alexandre and Soares (2004) afirmam que kel é um artigo definido que está em desenvolvimento no caboverdiano. Um dos testes em favor dessa hipótese seria a presença de possessivos. Segundo os autores, quando um possessivo está presente, kel/kes não poderia ocorrer sem o clítico demonstrativo.

A sentença (10) é utilizada pelos autores como controle, para exemplificar que o pronome possessivo pode ocorrer sem $\mathrm{kel} / \mathrm{kes}$.

(10) $\mathrm{N} \varnothing$ atxa rabes pamodie ka $\varnothing$ kumi 1SG PFV achar estranho porque 3 SG NEG PFV comer

\footnotetext{
${ }^{13}$ Tratamos essa questão também em Miranda (2013).
} 
nha kumida.

1SG.POSS comida.

Achei estranho porque ele não comeu minha comida.

(Alexandre and Soares, 2004:340)

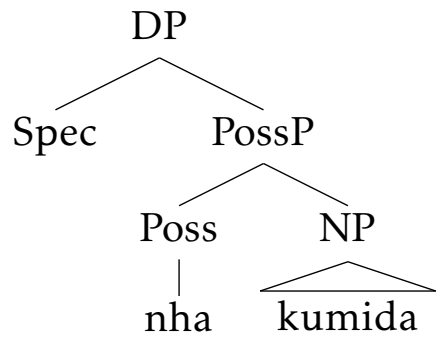

A sentença (11), por sua vez, é considerada agramatical, pois kel/kes não poderia, segundo a proposta dos autores, ocorrer com o pronome possessivo sem a presença do clítico (la ou li) posposto ao nome. Já a sentença (12), com $\mathrm{kel} / \mathrm{kes}$ juntamente com o pronome possessivo e somado ao clítico, é considerada gramatical. Representamos o NP a seguir.

(11) ${ }^{\star} \mathrm{Dja}$ bu odja kes nha fidju femia?

ADV 2SG.POSS olhar DEM 1SG.POSS filho fêmea

(Alexandre and Soares, 2004 : exemplo adaptado)

(12) Dja bu odja kes nha fidju femia li?

ADV 2SG.POSS olhar DEM 1SG.POSS filho fêmea ADV

Você já viu estas minhas filhas aqui?

(Alexandre and Soares, 2004 : exemplo adaptado)

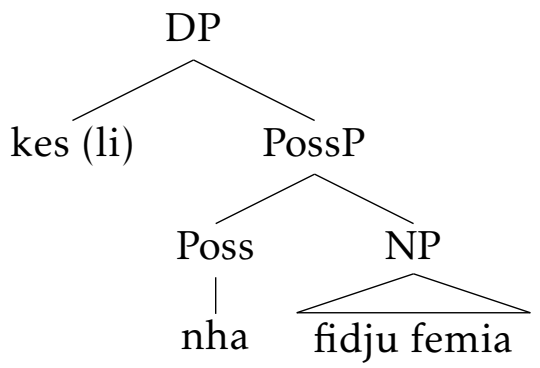

Como contra-argumento, no entanto, apresentamos os dados (13) e (14):

(13) Kel bu amigo $\varnothing$ tilifona.

DEM 2SG.POSS amigo PFV telefonar.

Aquele teu amigo telefonou.

(14) $\mathrm{Bu}$ nem ka $\varnothing$ dêxa-m kel bu livru. 2SG.POSS NEG NEG PFV deixar-1SG.OBJ DEM 2SG.POSS livro. 
Você nem deixou aquele seu livro para mim.

(Quint, 2000:183)

Em Miranda (2013), observamos através dos dados (13) e (14) que a hipótese apresentada por Alexandre and Soares (2004) sobre a alternância entre kel e os pronomes possessivos na mesma posição sintática não poderia ser sustentada e indicamos a necessidade de maior aprofundamento na análise sobre o que causa a agramaticalidade de (11). Logo, esse argumento não poderia ser utilizado para a defesa de kel como um artigo definido, dado que, conforme apresentamos acima, a coocorrência com pronomes possessivos é possível.

Outrossim, mesmo em português, língua que atestadamente possui artigo definido, tanto este quanto o pronome demonstrativo podem coocorrer com o pronome possessivo, como pode ser observado na representação a seguir.

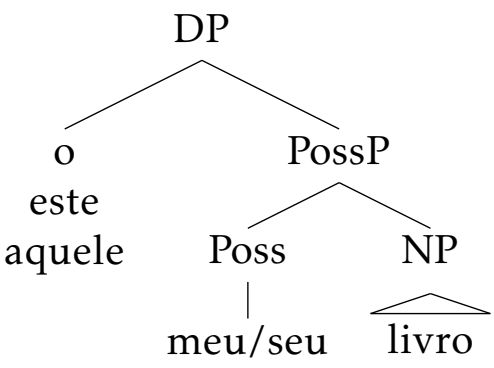

De volta às características de kel e de acordo com o que apresentamos em Miranda et al. (2010), essa partícula não pode ser utilizada para expressar generalizações (como ilustração, ver (15)). Aqui, chamamos a atenção para o argumento de Alexiadou et al. (2007) apresentado na discussão teórica sobre as classes artigo definido e demonstrativo, uma vez que as autoras apontam que o demonstrativo não admite leitura genérica.

Observamos que, mesmo com a presença da partícula aspectual de habitualidade, que poderia favorecer a leitura genérica, a presença de kel não permite tal leitura.

(15) *Tudu kel brasileru ta gosta di futibol.

Todo DEM brasileiro HAB gostar PREP futebol.

Para expressar leitura genérica, as formas adequadas seriam (16) e (17).

(16) Tudu kenha é brasileru ta gosta di futibol.

Todo quem ser brasileiro HAB gostar PREP futebol.

Tudo que é brasileiro gosta de futebol. 
(17) Tudu brasileru ta gosta di futibol.

Todo brasileiro HAB gostar PREP futebol.

Todo brasileiro gosta de futebol.

Kel também não pode ser utilizado para introduzir entidades desconhecidas: em um contexto no qual Maria foi assassinada brutalmente, a sentença (18) só será aceita se a pessoa que a proferir conhecer a identidade do assassino. Kel não poderia ser usado para referir-se a um assassino de Maria incógnito.

$$
\begin{aligned}
& \text { Kel ómi ki } \varnothing \text { máta Maria é dodu. } \\
& \text { DEM homem PRON.CONJ.PREP PFV matar Maria ser doido } \\
& \text { Aquele homem que matou (a) Maria é doido. }
\end{aligned}
$$

(Miranda et al., 2010)

Em Miranda et al. (2010) apontamos que, caso o falante saiba que foi João quem matou Maria, ele pode usar a sentença (19).

$$
\begin{aligned}
& \text { Djon kel ki } \varnothing \text { máta Maria. } \\
& \text { João DEM PRON.CONJ.PREP PFV matar Maria } \\
& \text { João, aquele que matou a Maria. }
\end{aligned}
$$

(Miranda et al., 2010)

Se João não estiver presente na situação, o falante pode valer-se das sentenças $(20)$ e (21):

(20) Kel dódu ki $\varnothing$ máta Maria é Djon.

DEM doido PRON.CONJ.PREP PFV matar Maria ser João

Aquele doido que matou Maria é o João.

(Miranda et al., 2010)

(21) Djon kenha ki $\varnothing$ máta Maria.

João quem PRON.CONJ.PREP PFV matar Maria

O João (foi) quem matou a Maria.

(Miranda et al., 2010)

As características arroladas acima parecem corroborar a hipótese de que, em caboverdiano, não há artigo definido e que kel(s) se comportaria principalmente como demonstrativo.

\subsubsection{Kel li, Kel la}

Kel pode ainda ocorrer com os advérbios li e la, em geral, pospostos ao nome modificado pelo demonstrativo. De acordo com Brüser et al. (2001), 
kel não diz nada sobre a proximidade ou distância do referente, se espacial ou temporal. O traço [+ / - distal (ou proximal)] do demonstrativo kel é realizado por meio dos advérbios $l i$ (ver (22) e (23)) e la (ver (24) e (25)), que indicam proximidade e distância do falante, respectivamente ${ }^{14}$.

(22) Ami $\varnothing$ panha kel latona li xei d'agu.

1SG.T PFV pegar DEM lata.GRAU ADV cheia PREP'agua

Eu peguei esta latona aqui cheia d'água.

(23) Ten un punhal da'kel grandura li.

ter DET punhal PREP'DEM grandeza ADV

Tem um punhal grandão assim.

(24) $\mathrm{N} \varnothing$ ben ku kónpra riba sacu simentu, pirgunta 1SG PFV vir PREP compra em.cima saco cimento pergunta kel mudjer lá, ki é nha kumadri, DEM mulher ADV PRON.CONJ.PREP ser 1SG.POSS comadre tudu alguém (ki nasci li é sim). todo alguém PRON.CONJ.PREP nascer ADV ser assim Eu vim com compra em cima do saco de cimento, pergunta para aquela mulher lá, que é minha comadre, todo mundo (que nasce aqui é assim).

(25) N ta recebê dôs kontu, si encomendadu mais 400 ${ }_{1} \mathrm{SG} \mathrm{HAB}$ receber dois conto se encomendado mais 400 escudos, na lojinha ki ten lá na escudos, PREP loja.GRAU PRON.CONJ.PREP tem ADV PREP kel buati lá.

DEM boate ADV

Eu recebo dois contos, se é encomendado mais quatrocentos escudos, na lojinha que tem lá naquela boate lá.

Veiga (2002:70) assinala que kel li indica a proximidade de quem fala (o espaço da primeira pessoa), ao passo que kel la pode ser usado tanto para indicar a proximidade da pessoa com quem se fala (o espaço da segunda pessoa) quanto o espaço da terceira pessoa.

\footnotetext{
${ }^{14}$ Para mais detalhes sobre essa argumentação, ver Miranda (2013).
} 


\subsubsection{Kriyol da Guiné-Bissau e o caboverdiano}

O kriyol da Guiné-Bissau e o caboverdiano compartilham diversas características. Dentre elas estaria o comportamento do pronome demonstrativo.

Kihm (1994) analisa kil do kriyol como demonstrativo distal. Para o autor, na gramática do kriyol, não há nenhuma marcação explícita quanto à eventual identificabilidade da entidade.

Na análise de Kihm, o uso de un em kriyol pode ser associado à introdução de novos referentes, como em (26), e de nomes sem determinantes, associados a referentes pressupostos, conforme (27).

(26) I yera ba un tarbaju garandi pa mi.

DET ser.PST PST DET trabalho grande PREP 1 SG.OBL

Este foi um grande trabalho para mim.

(Kihm, 1994)

(27) La ja tarbaju yera menus.

ADV já trabalho ser.PST menos.

Lá, o trabalho já foi menor.

(Kihm, 1994)

Em kriyol, a função anafórica pode ser realizada pelo especificador vazio, como caso especial de especificidade, mas também é possível através do uso do demonstrativo distal kil, embora frequentemente seja difícil decidir se este uso é anafórico ou dêitico.

$$
\begin{aligned}
& \text { Kil asasinus bin di elikóteru. } \\
& \text { DEM assassinos vir PREP helicóptero } \\
& \text { Os assassinos vieram de helicóptero. }
\end{aligned}
$$

(Kihm, 1994)

Em (28), notícia transmitida em um jornal, a função de kil não pode ser, segundo as análises de Kihm (1994), mais do que indicar que os assassinos referidos são os mesmos já mencionados anteriormente. Quando usado anaforicamente, kil não pode ser reforçado com la seguido do núcleo nominal. Kil asasinus la significa "aqueles assassinos", com força dêitica. A partícula kil em kriyol é analisada como demonstrativo distal; a proximidade ou distância é medida relativamente pelo falante e pode ser material ou ideal, referir-se a espaço ou tempo, ou ainda a ambos.

Observamos que tanto a introdução de novos referentes associada a un quanto a retomada de referente por meio de nomes sem determinantes ocorrem nas duas línguas, o caboverdiano e o kriyol. Todavia, diferentemente de kil do kriyol, kel não poderia ser analisado como demonstrativo 
distal sem a presença dos pronomes clíticos, uma vez que são estes que indicam a proximidade ou distância do falante, conforme apresentado na subseção 6.5.2.

\subsubsection{Kel li versus Es (li)}

No que concerne ao determinante es, Quint (2000) aponta que seria menos empregado que kel e essencialmente por contraste a ele, sendo utilizado apenas com nomes singulares. Quint (2009) argumenta que es seria equivalente ao demonstrativo este do português, e serviria para designar um ser ou coisa próximos no espaço ou no tempo.

Alexandre and Soares (2004) afirmam que não há dúvidas quanto ao estatuto de es como demonstrativo, mesmo quando ocorre sem o clítico -li.

Para Brüser et al. (2001), es "situa-se sempre espacialmente próximo do locutor ou temporalmente próximo do momento da enunciação".

Observamos em nossas análises, porém, que es, apesar de ser aceito quando apresentado em alguns contextos - mas não em todos, como mostraremos a seguir —, é pouco empregado na fala corrente dos caboverdianos, embora aparente possuir realmente uma função demonstrativa. Ao que parece, essa função estaria restrita mais a uma questão temporal do que à distância do falante.

Na sentença (29), "esses dias" têm de estar próximos ${ }^{15}$. O falante não sabe ao certo em que dia irá a Assomada, mas o dia tem de ser próximo - digamos, na semana corrente ou na seguinte. A sentença (29) não será adequada caso a ida a Assomada se dê em mais de uma semana. Nesse caso, será mais adequado dizer a sentença (30) e, aqui, o mês tem de ser o presente. Se a ida a Assomada der-se no mês seguinte, ou em outro mês distante, deve-se realizar uma referência explícita, tal como (31) ou (32).

(29) Es dia li $N$ ta bai pa Somada.

DEM dia ADV 1 SG HAB ir PREP Assomada

Esses dias eu vou para Assomada.

(30) Es mês li $\mathrm{N}$ ta bai pa Somada.

DEM mês ADV 1 SG HAB ir PREP Assomada

Este mês (aqui) eu vou para Assomada.

(31) Mês ki ben $\mathrm{N}$ ta bai pa Somada.

Mês PRON.CONJ.PREP vem 1 SG HAB ir PREP Assomada

No mês que vem eu vou para Assomada.

15 Observamos o fato de a interpretação não estar no singular. 
(32) Setenbru N ta bai pa Somada.

setembro 1 SG HAB ir PREP Assomada

Em setembro eu vou para Assomada.

Em um contexto no qual algumas pessoas estão conversando próximas ao falante, a sentença (33) não se emprega. Nesta situação, o falante oferece a sentença (34), apontando gestualmente para as pessoas ${ }^{16}$.

(33) *Es pesoa li sta papia.

DEM pessoas ADV estar conversar

(34) Kes pesoa / (gentis) la, es sta papia (manenti). DEM pessoa / (pessoas) ADV 3 PL estar conversar (agora)

Aquelas pessoas lá, elas estão conversando.

No caboverdiano, es é aceito para falar de um evento que teve lugar no passado recente, como a noite anterior, por exemplo, em (35). Entretanto, de modo inesperado, o determinante es não é utilizado para referir-se a algo que ocorre no momento da fala nem para referir-se a algum objeto que esteja na posse do falante.

Em (36), o informante refere-se à música que está tocando naquele exato momento na rádio. Já em (37), a criança refere-se à caneta que está em suas mãos, pedindo-a à sua mãe. Em (38), o falante está com duas colheres, uma em cada mão, e pede para escolher entre uma das duas.

(35) Es noti txobi txuba.

DEM noite chover chuva

Esta noite choveu.

(36) Kel musica li, $\mathrm{N}$ ka konxi.

DEM musica ADV, 1 SG NEG conhecer

Essa música (aí) eu não conheço.

(37) N kre kel li.

1SG querer DEM ADV

Eu quero esse aqui.

(38) Bu kre kel li o kel li?

2SG querer DEM ADV ou DEM ADV.

\footnotetext{
${ }^{16} \mathrm{Um}$ fato interessante é que es, referindo-se a seres animados no singular, causará estranhamento aos falantes nativos. Nesse caso, ou seja, quando nós, pesquisadores, usamos es para referir-nos a seres animados no singular, na grande maioria das vezes o falante nos "corrigirá", afirmando que es só pode ser utilizado quando houver mais de uma pessoa. Esse estranhamento pode ser causado, talvez, pelo fato de o pronome de terceira pessoa do plural ser homófono ao demonstrativo.
} 
Você quer essa ou essa (aqui)?

Embora es seja aceito pelos falantes - exceto no caso de seres animados - quando lhes é apresentado o contexto, esse pronome não se mostra tão produtivo na língua.

Para Veiga (2002), tanto es, es li quanto kel li indicam proximidade da pessoa que fala. Observamos que es encontra-se em expressões cristalizadas como, por exemplo, "es anu" (esse ano), ou "es noti" (essa noite) e ainda em expressões de saudação, como "Es bida?" ou "Es korpu?". Contudo, ao que parece, a função de indicar proximidade do falante parece ser mais associada a kel li.

Para Baptista (1997) a diferença semântica entre kel e es é que, enquanto aquele pode indicar proximidade e distância, es estaria restrito apenas à indicação de proximidade.

É interessante observar ainda que Quint (2009) assinala - por se tratar de uma obra de ensino da língua - que, em caso de dúvida, deve-se utilizar sempre $k e l$, exceto em expressões que se refiram ao momento da enunciação ou do futuro próximo.

\subsection{Considerações do capítulo}

Neste capítulo apresentamos o comportamento de kel, kel li, kel la e es (li) dentro do sintagma nominal do caboverdiano. Apontamos que nessa língua não há artigo definido e que kel / kes, analisado com um demonstrativo, é utilizado para veicular definitude. Tal uso, todavia, não pode ser considerado frequente, uma vez que sintagmas anafóricos são retomados, em geral, sem a presença do demonstrativo.

Apontamos ainda que os usos dêiticos estão frequentemente associados ao uso de kel li e kel la, que indicam, respectivamente, proximidade e distância do falante. O uso de es (li) para indicar proximidade, por sua vez, parece estar restrito a indicações temporais e expressões cristalizadas.

No que diz respeito às controvérsias geradas sobre o estatuto de $\mathrm{kel}$, observamos que mesmo os comportamentos tomados por alguns autores para defender seu estatuto como artigo definido são típicos dos demonstrativos como, por exemplo, retomar um referente no discurso. Ademais, de acordo com C. Lyons (1999), os demonstrativos são sempre definidos.

Por fim, observamos que, conforme já mencionado, não há nos registros do World Atlas of Language Structures Online nenhuma língua que possua, ao mesmo tempo, a característica de possuir como único artigo o indefinido e ainda usar um demonstrativo como marcador de definido. No 
entanto, diferente do que consta no WALS, nossas análises apontam para, pelo menos, duas línguas que compartilham dessas duas características concomitantemente, a saber, o caboverdiano e o kriyol da Guiné-Bissau. 


\section{CAPÍTULO 7}

Uma

\subsection{Situando a questão}

Nos estudos sobre o sintagma nominal do caboverdiano, uma é tomado por alguns estudiosos como a contraparte feminina do determinante indefinido $u n^{1}$.

Baptista (2002:29), além de considerá-lo como a contraparte feminina de un, afirma, em nota de rodapé, que os informantes caboverdianos o utilizam em raras ocasiões. Segundo a autora, o uso de uma apresenta-se tão escasso em seu corpus que ela poderia assinalá-lo como meramente acidental e não sistemático ${ }^{2}$.

Em nossas análises, no entanto, observamos que a utilização de uma dá-se de modo frequente na língua caboverdiana. Ademais, uma não compartilharia das características da classe dos artigos indefinidos, como mostraremos mais adiante.

Partindo do fato de que em caboverdiano não há concordância de gênero - exceto para seres animados, ver 3.2.2 - uma não poderia ser sempre a contraparte feminina de $u n$. Em outras palavras, uma não realizaria concordância de gênero com os nomes que modifica, uma vez que ocorre

\footnotetext{
${ }^{1}$ Agradeço a Francisco Lopes por ter chamado a minha atenção sobre o comportamento de uma no caboverdiano.

${ }^{2}$ Observamos o fato desse item ser pouco abordado nas análises sobre o sintagma nominal do caboverdiano. Em geral, menções sobre o comportamento de uma são restritas a poucos parágrafos ou notas de rodapé.
} 
sem restrições com nomes considerados no português como masculinos (1) e femininos (2). De acordo com nossas análises, uma e un não seriam alomorfes; uma pertenceria, desta feita, a uma classe distinta.

(1) Ami $\varnothing$ peska UMA pexi!

1SG.T PFV pescar SING peixe

Eu pesquei o maior peixão!

(2) Ami $\varnothing$ konxi UMA minina bunita!

1SG.T PFV conhecer SING menina bonita

Eu conheci a menina mais linda!

Neste capítulo, apresentaremos os contextos de ocorrência de uma em caboverdiano, bem como suas restrições de uso, destacando os elementos que o distinguem da classe dos artigos indefinidos, bem como da classe dos modificadores de grau.

\subsection{Por que uma não seria um artigo indefinido?}

Parece consenso entre grande parte dos estudiosos do caboverdiano que uma é um artigo indefinido - exceto por Veiga (2012), que o coloca como advérbio. Propomos, porém, que uma não compartilha das características de um artigo indefinido e que não deveria ser tratado como tal.

Em caboverdiano, uma seria utilizado exclusivamente quando o falante pretende enfatizar alguma propriedade do nome ou do adjetivo com o qual se combina. Sua função seria a de destacar o nome que modifica e não veicular indeterminação. A sentença (3) é produzida pelo falante em um dia de muito calor e só seria apropriada em um contexto no qual o falante considera o calor muito acima da média.

(3) Ami sta ku UMA kalor!

1SG.T estar PREP SING calor

Estou com o maior calorão!

Muito importante também é o fato de uma sempre ocorrer com acento prosódico enfático, não sendo reconhecido na língua sem esse acento. Os artigos, por outro lado, devem caber em todos os contextos pragmáticoconversacionais, não só nos enfáticos.

Em contraposição, C. Lyons (1999:36) aponta que os artigos definido e indefinido (the e $a$ do inglês) são formas fonologicamente fracas e essa característica os tornaria membros básicos e não marcados de suas respectivas classes. Logo, o acento fonológico de uma também o afasta da classe 
dos artigos indefinidos.

\subsection{Modificadores de grau: discussão teórica}

O fato de uma sempre destacar o nome que modifica nos levou, em primeiro lugar, a analisá-lo como um possível modificador de grau. As análises realizadas, todavia, o afastam desta classe, como veremos.

Grande parte dos trabalhos sobre modificadores de grau tratam de itens como muito, que gerariam uma leitura escalar.

Para o inglês, Kennedy and McNally (2005) afirmam que very está restrito a modificar expressões que são, ao mesmo tempo, adjetivais e graduais, além de modificar escalas totalmente abertas ${ }^{3}$ e ser manipulável pelo contexto.

(4) The international space station is very expensive. A estação espacial internacional é muito cara ${ }^{4}$.

(5) The coffee at the airport is very expensive. O café do aeroporto é muito caro ${ }^{5}$.

Os autores salientam que tomar os adjetivos expensive, old e long como adjetivos de escala aberta pode parecer contraintuitivo, já que seria natural imaginar que tanto velho quanto caro possuem um valor mínimo que seria equivalente a zero. Contudo, de modo a defender a hipótese, apontam que a não aceitabilidade de modificadores maximizando os seus antônimos seria indicativo de que esses são adjetivos de escala aberta.

A diferença entre expensive e very expensive, segundo Kennedy and McNally (2005), é que o último, apesar de denotar uma propriedade tal como o primeiro, tem padrão relativo aumentado por uma certa quantidade.

Para os autores, no uso normal, adjetivos absolutos rejeitam a modificação por very. A aceitabilidade, por vezes, de very com adjetivos absolutos (tal como aberto) poderia, contudo, ser explicada nos termos da teoria dos halos pragmáticos.

A teoria dos halos pragmáticos, apresentada por Lasersohn (1999), propõe que o contexto pode associar a qualquer expressão da língua um conjunto de denotações do mesmo tipo, que diferiria apenas em uma medida aceitável da real denotação, o que pode ser pragmaticamente ignorável

\footnotetext{
${ }^{3}$ Escalas totalmente abertas são as que não possuem um valor máximo nem um valor mínimo, tal como velho e caro.

${ }^{4}$ A estação espacial é considerada cara se comparada a outros projetos espaciais.

5 O café é muito caro se comparado aos cafés em geral.
} 
pelo contexto. Isso é o halo pragmático. Qualquer valor no halo pragmático de uma expressão $\alpha$ conta como aproximação informativa e aceitável de $\alpha$ e estaria "próximo da verdade".

Por exemplo, se uma pessoa chegar a um local às 15 ho 5 e disser que chegou às 15 hoo, essa informação não será considerada falsa, pois está próxima da verdade e essa pequena diferença é pragmaticamente ignorada pelo contexto.

Kennedy and McNally (2005), embora atribuam a interpretação de very com adjetivos absolutos aos halos pragmáticos, dizem-se neutros em relação à explicação de como se dá exatamente essa interpretação; afirmam que, quando o contexto é controlado para forçar o uso absoluto, vê-se com clareza a sensibilidade desse modificador de grau em relação à distinção de padrão relativo/absoluto (6) e (7) .

(6) ??I always leave the door to my office very open.

Eu sempre deixo a porta da minha sala muito aberta.

(7) ??That drug is currently very available.

Essa droga está muito disponível atualmente.

Parece necessário observar a ocorrência de very de modo mais detido, já que essa sensibilidade pode não ser tão efetiva, uma vez que há necessidade de controlar o contexto para forçar tal uso. No português brasileiro, por exemplo, o dado (6) não causa estranhamento.

Em relação ao francês, Doetjes (2007) assinala que beaucoup sempre corresponde a uma expressão de grau alto e opera no significado de um predicado que tem de ser interpretado como escala. Essa escala corresponde, no caso de NPs e VPs, ou a uma escala global, com predicados massivos, ou a uma escala discreta, com predicados contáveis plurais.

Expressões como beaucoup não poderiam combinar-se com NPs singulares porque eles correspondem a uma quantidade específica e não a uma escala. A quantidade de referência de beaucoup seria interpretada como uma entidade global "mais que $n$ ", onde $n$ é contextualmente determinado por uma norma.

Sylvie va beaucoup au cinéma.

Silvia vai muito ao cinema ${ }^{6}$

Expressões como beaucoup são tipicamente encontradas em contextos que especificam grau. Quando combinadas com adjetivos, as expressões de

\footnotetext{
${ }^{6}$ Observamos que Doetjes (2007) contrapõe beaucoup a souvent. Por isso, a grande maioria dos exemplos apresentados pela autora (com beaucoup) gera uma leitura iterativa.
} 
grau, a depender do contexto, introduzem uma escala qualitativa ou de intensidade. De acordo com a autora, a generalização que pode ser feita sobre os contextos em que as expressões de grau são utilizadas é a de que o sintagma modificado deve introduzir uma escala.

Embora Doetjes (2007) considere que beaucoup seja sempre uma expressão de grau, assim como o muito do português brasileiro ele não é utilizado exclusivamente para expressar grau. Por exemplo, a expressão "Merci beaucoup” não parece veicular grau, porque não há expressões concorrentes com outro grau, como "Merci un peu", por exemplo.

Já em relação ao português brasileiro (PB), Quadros Gomes (2009:174) argumenta que muito pode modificar qualquer tipo de adjetivo. De acordo com a autora, o produto da modificação é sempre uma escala aberta, e tem sempre parâmetro relativo. Muito pode marcar um grau além do parâmetro, e esse pode vir explicitado na sentença como, por exemplo (9a) e (9b):

(9) a. A banheira está muito cheia para dar banho no bebê.

b. A banheira está muito vazia para mim.

(Quadros Gomes, 2009:163)

Ainda de acordo com Quadros Gomes (2009), em relação a muito, o produto da modificação de um adjetivo é um valor dependente do contexto. Como modificador nominal, muito não define uma quantidade e pode vir interno em outros determinantes, como "os muitos meninos". No que concerne aos eventos, muito modificaria diretamente o VP e construiria uma intensificação vaga. Não se pode definir precisamente a quantidade em causa, dada a manipulação contextual embutida em "muito".

\subsection{Por que uma tampouco seria um modificador de grau?}

Em Miranda et al. (2010:11), apontamos uma não como a contraparte feminina de $u n$, mas como um intensificador que aponta para o maior grau, tanto de quantidade quanto de qualidade. Argumentamos ainda que "uma é um operador que marca o caráter excepcional do referente quanto ao grau extremado de certa qualidade ou dimensão que o destaca".

Diferentemente do que nós mesmos apontamos em Miranda et al. (2010), uma tampouco poderia ser classificado como intensificador, ou modificador de grau, nos termos de Kennedy and McNally (2005), por não veicular grau.

Nesta subseção, verificaremos o motivo pelo qual uma não poderia ser 
analisado como intensificador, tal como apontado em Miranda et al. (2010), tampouco como modificador de grau nos termos de Kennedy and McNally (2005) - ou, ainda, como advérbio de grau nos termos de Doetjes (2007).

\subsubsection{Txeu}

No caboverdiano, o modificador de grau equivalente ao very do inglês, beaucoup do francês e ainda ao muito do português brasileiro seria txeu.

Nos exemplos (10) e (11), o grau de contentamento do falante excede a média ou a norma da escala no contexto em questão, ou seja, a escala de grau de contentamento. Em (10), contudo, o grau excedido está acima do grau expresso por (11), pois quando o falante produz (10), ele está mais do que muito contente - se assim fosse, o mais adequado seria dizer (11).

(10) Ami sta UMA kontenti! 1SG.T estar SING contente Estou super contente!

(11) Ami sta txeu kontenti! 1SG.T estar muito contente Estou muito contente!

Aqui, escalas não precisam ser construídas por números. O importante, para Kennedy and McNally (2005), é que, seja qual for o status ontológico dos graus - se correspondem a números, a classes de objetos ou construtos mentais -, eles podem variar.

Os autores propõem que essa variação se dá em termos da distinção entre escala aberta e fechada. Não é essa, no entanto, a distinção que tomamos como base para a explicação dessa variação, pelo menos não no caboverdiano, e sim os tipos dos nomes sobre os quais o modificador opera.

Em caboverdiano, txeu modifica nomes e verbos e o resultado dessa modificação, assim como no PB e no francês, é contextualmente dependente.

Nos dados a seguir, não há uma quantidade específica. Seria o que Quadros Gomes chama de intensificação vaga. Para os dados (13) e (16) seria mais adequado considerar a cardinalidade vaga, posto que não se pode definir exatamente a quantidade expressa nos dados.

Assim como os modificadores de grau, txeu não está restrito a uma ordem adverbial canônica, ocorrendo tanto antes - (12) e (13) - quanto depois do nome - (14) e (15) - ou verbo - (16) - que modifica, além de modificar nomes contáveis plurais - (16) e (13) -, nomes abstratos - (17) e (14) - e massivos - (12).

Os dados (14) e (17) podem ser explicados em termos de escalas; o grau 
de saudade e de "enganação" estariam acima do que pode ser considerado a média. Todavia, como esses são nomes abstratos, o padrão da escala varia de acordo com a norma considerada pelo falante e a escala gerada é de intensidade, não de quantidade. O grau superado nesses itens é o grau considerado pelo falante, o que é contextualmente dependente.

(12) Santu Onton ten txeu águ.

Santo Antão ter muito água

Santo Antão tem muita água.

(13) Ta ten txeu mininus ki ta ba skola. HAB ter muito meninos PRON.CONJ.PREP HAB ir escola

Tem muitos meninos que vão para escola.

(Baptista, 2002:37)

(14) Mundu sta nganadu txeu.

Mundo estar enganado muito.

O mundo está muito enganado.

(Baptista, 2002:102)

(15) Dinheru txeu ta máta algén. Pamódi dinheru txeu, bu Dinheiro muito $\mathrm{HAB}$ matar pessoas porque dinheiro muito $2 \mathrm{SG}$ ta usa puder di dinheru.

HAB usar poder PREP dinheiro.

Muito dinheiro mata as pessoas. Porque, com muito dinheiro, você usa o poder dele.

(16) Livru go nu tene txeu.

Livro agora $1 \mathrm{PL}$ ter muito.

Agora temos muitos livros.

(Baptista, 2002)

(17) $\mathrm{N}$ ten txeu sodádi-bo.

1 SG ter muito saudade-2SG

Tenho muita saudade de você.

(Quint, 2000:202)

Diferentemente de uma, txeu não parece estar associado exclusivamente a uma superação de expectativa. Txeu, tal como muito do PB, pode modificar nomes sem necessariamente ter uma ideia de escala associada a ele (18) e (19).

(18) Kada dia el sta sabe mas txeu.

Cada dia 3 SG estar saber mais muito

lit: A cada dia ele/ela sabe muito mais. 
A cada dia ele sabe mais.

(Silva, 1985: 140 em Baptista, 2002: 97)

(19) Ami dja $\varnothing$ senta txeu.

1SG.T ADV PFV sentar muito

Eu já fiquei sentado (tempo) demais.

Os dados (20), (21) e (22) também não parecem ser interpretados em escala de graus.

(20) Ami ta konxi txeu algén.

1 SG.T HAB conhecer muito pessoas

Eu conheço muita gente.

(21) Planta ten txeu saúdi.

planta ter muito saúde

As plantas são muito saudáveis.

(22) Ami panhatxeu sufrimentu enorme. 1SG.T pegar muito sofrimento enorme

Passei por muito sofrimento.

Txeu também ocorre em contextos comparativos como em (23) e (24) e, ainda, serve como resposta: (25) é dado como resposta pelo informante à pergunta se ele possui muitos porcos.

(23) É quenti mas txeu ki friu. é quente mais muito PRON.CONJ.PREP frio É muito mais quente do que frio.

(24) Prétu é mas txeu, braku é mas pocu. Preto é mais muito branco é mais pouco Tem mais preto do que branco.

(25) Non é ka txeu. Ami ten dôs porku lá. NEG é NEG muito. 1 SG.T ter dois porco ADV Não é muito não, eu tenho dois porcos lá.

As sentenças (26) e (27) poderiam ser aceitáveis com a ocorrência de uma. No entanto, a interpretação - com uma — seria de quantidade absolutamente acima do esperado, ou seja, uma quantidade surpreendente.

(26) Grógu era txeu.

grogue ser.PST muito

Tinha muito grogue. 7

${ }^{7}$ Aguardente produzida no país à base de cana-de-açúcar. 
(Rodrigues, 2007)

(27) $\mathrm{Na}$ órta ten txeu makaku.

PREP horta ter muito macaco

Na horta tem muito macaco.

(Rodrigues, 2007)

Em alguns contextos, txeu comporta-se como modificador de grau, gerando uma leitura escalar contextualmente dependente. Contudo, assim como o muito do $\mathrm{PB}$, não ocorre exclusivamente como modificador de grau. $\mathrm{O}$ importante aqui é que txeu nem sempre gera uma escala. Por esse fato, não pode ser considerado exclusivamente como um modificador de grau nos termos de Doetjes (2007) ou Kennedy and McNally (2005).

\subsubsection{Uma}

Em (28) o informante, em conversa espontânea, falava a respeito de um peixe que pescou no ano anterior; disse que era o maior peixe que ele havia pescado, um atum de noventa e nove quilos. Nesse caso, uma opera diretamente sobre o tamanho do objeto.

(28) Ami $\varnothing$ peska UMA pexi!

1SG.T PFV pescar SING peixe

Eu pesquei o maior peixão!

A sentença (29) só é adequada para se referir a uma chuva extremamente forte. Não seria possível utilizar uma para referir-se a um dia chuvoso, em que a chuva não tenha sido de grande intensidade, mesmo que tenha chovido durante todo o dia.

(29) Oji $\varnothing$ txobe UMA txuba!

Hoje PFV chover SING chuva

Hoje deu a maior chuvarada!

Em (30) a informante, ao contar um episódio sobre o nascimento de um dos seus filhos, fala que o marido trouxe uma trouxa cheia de roupas para a criança. De modo mais preciso, nesse contexto, uma aponta para a quantidade de roupas dentro da trouxa e é essa quantidade que supera a expectativa do falante. Ou seja, havia muito mais roupas do que se pode considerar normal dentro do contexto relevante, como se pode observar na descrição da trouxa de roupas feita pela informante em (31). Chamamos a atenção para a explicitação feita pela informante após a utilização de uma. 
(30) N'otu diâ nha maridu $\varnothing$ txiga ku UMA troxa!

PREP'outro dia 1 SG.POSS marido PFV chegar com SING trouxa No outro dia, meu marido chegou com uma trouxa (de roupa) imensa!

(31) $\mathrm{Ku}$ dôs panu téra (...) $\mathrm{Ku}$ róbi, $\mathrm{ku}$ kamisa di nóti, PREP dois pano terra (...) PREP robe PREP camisa PREP noite, $\mathrm{ku}$ dôs par di sapatinhu mininu, ku dôs chapéu PREP dois par PREP sapato.DIM menino, PREP dois chapéu di mininu, ku quatu kamisa di mininu, ku rôpa, PREP menino, PREP quatro camisa PREP menino, PREP roupa, $\mathrm{ku}$ tudu kusa. PREP tudo coisa Com dois "panos de terra" (...), com robe, com pijama, com dois pares de sapatinho de menino, com dois chapéus de menino, com quatro camisas de menino, com roupa, com todas as coisas ${ }^{8}$.

Em (32) a informante diz que estava com uma barriga enorme, prestes a dar à luz. Nesse caso, uma aponta para o tamanho.

(32) Ami tinha UMA bariga! 1SG.T ter.PST SING barriga Eu estava com o maior barrigão! (de grávida)

Nos dados apresentados até agora, podemos observar que a modificação gerada por uma está mais associada à expectativa do falante, conforme apontamos em Miranda et al. (2010), e é contextualmente dependente, não gerando uma quantidade específica. Parece haver, tal como no muito do PB, uma manipulação contextual embutida em uma.

A sentença (33) foi apresentada em um teste de aceitabilidade. Mesmo aceitando a expressão (33), na grande maioria dos casos, o dado (34) foi também oferecido espontaneamente pelos falantes. Nesse caso, consideramos ser (34) o dado adequado para o contexto em que o falante quer indicar que uma pessoa possui um pé bem grande 9 .

$$
\begin{aligned}
& \text { El ten UMA pé! } \\
& \text { 3SG ter SING pé } \\
& \text { Ele tem um pezão! }
\end{aligned}
$$

\footnotetext{
${ }^{8}$ Pano de terra é um tecido feito em tiras de algodão produzido em teares no próprio país.

${ }^{9}$ Salientamos que, aparentemente, testes de aceitabilidade não seriam os mais adequados para elicitar a ocorrência de uma, por não favorecer seu uso. Diante disso, não descartamos a hipótese do dado (33) poder ser utilizado no contexto apresentado.
} 
(34) El ten pesóna!

3SG ter pé.GRAU

Ele tem um pezão!

O par de dados (33) (34) poderia nos levar a imaginar que uma e-óna seriam intercambiáveis para a expressão de grau no caboverdiano, principalmente no que diz respeito ao tamanho. Contudo, o dado (28) nos mostra que uma também modifica o tamanho do objeto, o que descartaria essa hipótese. $\mathrm{O}$ dado (35) refuta ainda mais a hipótese mostrando, inclusive, que uma pode ocorrer juntamente com a desinência -óna.

Em (35), o falante, em conversa espontânea, contava sobre um sapato que o amigo possui; sapato extremamente chamativo, tão chamativo que, segundo ele, o amigo deveria ser preso por perturbar a ordem pública. Nesse caso, tanto uma quanto -óna operam sobre a característica do sapato, e não sobre o tamanho extremado. Aqui, especificamente, o que está acima da escala considerada normal é tanto a cor quanto a forma do sapato, e essa leitura é capturada contextualmente.

(35) El tinha UMA sapato, UMA sapatóna, UMA sapato ${ }_{3}$ SG ter.PST SING sapato SING sapato.GRAU SING sapato bermedju!

vermelho

Ele tinha um sapato, um sapatão (muito chamativo), um sapato vermelhaço!

Em (36), trata-se de um contexto em que o informante fala a respeito de certa garota que conheceu em uma festa e que é, segundo ele, a garota mais bonita que ele já conheceu. A sentença (37) sem o adjetivo soou estranha ao falante, o que reforçaria a hipótese da sua não interpretação como artigo indefinido.

(36) Ami $\varnothing$ konxi UMA minina bunita! 1SG.T PFV conhecer SING menina bonita Eu conheci a menina mais linda!

(37) \#Ami $\varnothing$ konxi UMA minina! 1SG.T PFV conhecer SING menina

Uma parece apontar para uma característica extremada, seja essa característica o tamanho, a quantidade ou a qualidade. Caso fosse considerado modificador de grau, que gera uma escala, deveríamos considerar que a escala gerada sempre aponta para o grau máximo, independentemente do tipo de dimensão considerada na escala. 
A análise dentro de uma perspectiva escalar parece não ser tão apropriada para uma, como foi para txeu. Em txeu - quando comporta-se como um modificador de grau - a escala gerada é contextualmente dependente, e não se pode definir a quantidade gerada pela escala, apenas que está acima do que seria considerado a média. No caso de uma, seria sempre o ponto mais alto da escala. Txeu gera tanto uma intensidade quanto uma cardinalidade vaga. Uma não parece denotar uma cardinalidade vaga, nem tampouco uma intensificação vaga, uma vez que o grau expresso por ele será sempre o grau máximo.

Ademais, quando não se trata de tamanho extremado, a utilização de uma diretamente com o nome não parece ser considerada aceitável. Diferentemente de txeu, uma parece não veicular, por si só, toda a informação relevante. Comparem-se os dados (38) e (39).

(38) \#Ami $\varnothing$ konxi UMA minina! 1SG.T PFV conhecer SING menina

(39) Ta ten txeu mininus ki ta ba skola. HAB ter muito meninos PRON.CONJ.PREP HAB ir escola Tem muitos meninos que vão para escola.

Em suma, a teoria que trata dos modificadores de graus parece não capturar, nem explicar, determinadas características de uma que serão arroladas nas próximas seções.

-óna

Na subseção 7.4.2, apontamos a questão da coocorrência de uma e -óna. Apresentaremos, sucintamente, as características da desinência -óna que serão importantes para a discussão dos dados mais adiante.

O sufixo -óna é considerado aumentativo por grande parte dos estudiosos do caboverdiano. Quint (2010:219) assinala que, quando combinado com "nomes masculinos", esse sufixo possui um valor enfático. Logo, segundo o autor, uma pedróna "designa uma pedra ainda maior do que as merecedoras da designação uma pedron" ${ }^{10}$.

A despeito da afirmação feita pelo autor, acentuamos novamente que o caboverdiano não distingue gênero de seres inanimados. Assim, não seria adequado considerar que -óna possui valor enfático quando se combina com nomes masculinos, uma vez que, especialmente no exemplo oferecido por Quint (2010), não há tal distinção. Ao que parece, esse sufixo possuiria valor enfático em todas as suas ocorrências.

${ }^{10} \mathrm{~A}$ forma simples do nome é pédra. 
Em (40), -óna é utilizado para dar ênfase ao tamanho do bode. Na sequência do diálogo, o falante ainda explica o tamanho do bode; ver (41), utilizando o nome sem o sufixo -óna.

(40) Óki ben bodóna el ta odja, el ta máta. Quando vir bode.GRAU 3 SG HAB olhar 3 SG HAB matar Quando vem o bodão, ele olha e mata.

(Rodrigues, 2007)

(41) Bódi era grandi, bódi era tamanhu! bode ser.PST grande bode ser.PST muito.alto O bode era grande, o bode era enorme!

(Rodrigues, 2007)

Tanto em (42), quanto em (43) o sufixo -óna aponta para o tamanho. Mais especificamente, para o tamanho da lata e para o tamanho da subida, respectivamente.

(42) Ami panha kel latóna li xei d’agu.

1SG.T apanhar DEM lata.GRAU ADV cheio PREP'agua

Eu pego esta latona aqui cheia de água.

(43) Nun subidóna ki ten lá Son Jorge.

PREP subida.GRAU PRON.CONJ.PREP ter ADV são jorge

Numa subidona que tem lá em São Jorge.

A nosso ver, o sufixo -óna apontaria exclusivamente para o tamanho do objeto, mas não estaria relacionado a uma superação de expectativa do falante, o que pode indicar que esse sufixo não poderia ser intercambiável com uma, já que não expressariam a mesma informação e, por conseguinte, não poderiam formar um paradigma. Enquanto o sufixo -óna seria utilizado como um sufixo aumentativo, uma seria utilizado para expressar uma característica extremada que não se restringe apenas ao tamanho.

\section{Adjetivos que expressariam grau}

Finalizando a abordagem a respeito de graus, em caboverdiano, alguns adjetivos podem ser utilizados para expressar ênfase. Quint (2000:148) cita pelo menos quatro: álta (44) e (45), bruta (46), nháku (47) e sépa (48).

(44) Alta son!

SING som

Que música boa! 
(45) Alta kamiza!

Int camisa

Que camisa bonita (da hora)!

(46) UMA bruta sónu!

SING Int sono

Um baita sono!

(Quint, 200o: 148)

(47) É nháku membra!

ser Int namorada

É uma super namorada (muito boa)!

(Quint, 2000:148)

(48) Sépa kása!

Int casa

(Que) casa grande!

(Quint, 2000:148)

Em (46), o autor não deixa claro se a intensificação é realizada somente pelo adjetivo ou se uma tem algum papel nessa intensificação. Acreditamos ser necessário testar este dado para verificar, por exemplo, se o sono de uma bruta sónu é maior que o de bruta són ${ }^{11}$. No entanto, esses itens seriam utilizados exclusivamente para a expressão de grau na língua.

\section{7·5 Evidenciais: abordagem teórica}

Outra possibilidade de análise quanto à contribuição semântica de uma seria tratá-lo como operador de evidencialidade. Aikhenvald (2004) define evidencialidade como uma categoria linguística cujo sentido primeiro seria manifestar a fonte de informação. Essa categoria pode ser expressa de modo variado. Algumas línguas possuem afixos ou clíticos, enquanto outras possuem marcação de evidencialidade conectada a outras categorias. A autora afirma ainda que somente de forma ocasional pidgins e línguas crioulas apresentam evidenciais.

Basicamente, os parâmetros empregados em línguas com evidencialidade gramatical cobrem, segundo Aikhenvald (2004), informações sensoriais, vários tipos de inferências e relato verbal. Os parâmetros semânticos recorrentes seriam:

I. Visual: cobre informações adquiridas por meio visual;

\footnotetext{
${ }^{11}$ Voltaremos a essa questão logo mais.
} 
II. Sensório não visual: cobre informações adquiridas através da audição e é tipicamente estendida ao olfato, ao paladar e, algumas vezes, ao tato;

III. Inferência: baseado em indícios visíveis ou tangíveis;

IV. Suposição: baseado em indícios não visíveis, o que pode incluir raciocínio lógico, suposição ou simplesmente conhecimento geral;

V. Boato: para informações relatadas sem nenhuma referência à fonte;

VI. Citativo: informações relatadas com referência explícita à fonte citada.

Faller vem realizando uma série de estudos sobre os evidenciais em quechua de Cuzco e os analisa, dentro da teoria dos atos de fala, como modificadores ilocucionários que adicionam ou modificam as condições de sinceridade. Em Faller (2002), essa autora argumenta que o termo "evidencialidade" é usado para referir-se à codificação gramatical do conhecimento do falante. Em asserções, essa experiência do falante pode ser identificada com a fonte de informação veiculada pelo enunciado.

Haveria três tipos principais de fonte de informação codificadas pelos evidenciais: acesso direto, relatado por outros e inferidos.

Os evidenciais arquetípicos, de acordo com Anderson (1986), citado por Faller (2002), devem apresentar as seguintes propriedades:

a. mostrar o tipo de justificativa para uma afirmação factual disponível para a pessoa que realiza a asserção;

b. não serem, eles mesmos, a predicação principal da sentença, mas uma especificação adicionada à afirmação factual;

c. terem a indicação de evidência como seu sentido primeiro, não apenas como inferência pragmática;

d. morfologicamente, serem flexões, clíticos ou elementos sintaticamente livres.

Conforme mencionado, Faller analisa os evidenciais em quechua como operadores ilocucionários. A lógica ilocucionária desenvolvida por Searle and Vanderveken $(1985)$ traz, como principal objetivo, o de formalizar as propriedades lógicas da força ilocucionária. $\mathrm{O}$ ato ilocucionário consistiria de uma força $F$ e de um conteúdo proposicional $P$. Os elementos que modificam $F$ podem ser chamados de modificadores ilocucionários. 
Davis et al. (2007) analisam o valor pragmático das sentenças evidenciais e mostram que os morfemas evidenciais gramaticalizados recaem em algumas categorias como experiência pessoal, percepção direta, inferência, conjectura e outras. Os autores afirmam que diferentes línguas escolhem diferentes subconjuntos das categorias evidenciais e que haveria, ainda, uma variação considerável no modo como os diferentes tipos de morfemas relacionam-se com uma informação específica.

O componente de sentido que parece derivar mais diretamente da presença dos morfemas evidenciais seria um comprometimento do falante em relação à existência de uma situação de certo tipo. A contribuição dos evidenciais seria puramente pragmática, no sentido de que parecem operar sobre o contexto de interação e não no sentido de qualquer enunciado em particular. Podem ser percebidos como fortalecimento global da força assertiva de um enunciado declarativo. $\mathrm{O}$ fortalecimento geralmente ocorreria com a experiência pessoal e direta (Davis et al., 2007).

Os evidenciais marcariam um tipo particular de estratégia do falante: ao usar um evidencial, o falante engatilha um contexto de comparação de tipo particular.

Em sentenças declarativas regulares, a estratégia pragmática do falante ao usar o evidencial seria, de acordo com os autores, deslocar o limiar para um ponto em que a asserção respeite a máxima de qualidade. A asserção $S$ seria julgada pragmaticamente nesse novo contexto.

\subsection{Uma seria um operador ilocucionário?}

Uma do caboverdiano não se enquadraria na teoria da evidencialidade em sentido estrito, uma vez que não codifica a fonte de informação do falante em relação aos parâmetros apresentados por Aikhenvald (2004) — ver 7.5. Ou seja, não há uma especificação se a fonte de informação é visual, não visual ou ainda por inferência ou suposição.

Uma noção relevante aos nossos propósitos é a de informação pessoal. Faller (2002:18) considera informação pessoal a informação sobre eventos da vida privada do falante. A melhor fonte de informação possível seria determinada em termos de "acesso direto". Em eventos observáveis, o acesso mais direto seria a percepção do evento.

Ao que parece, uma estaria associado a uma experiência pessoal do falante e o sentido derivado estaria de acordo com o apontado por Davis et al. (2007), ou seja, um comprometimento do falante em relação à existência de uma situação de certo tipo. Uma marcaria a estratégia do falante de apontar para uma característica extremada, considerada conforme a experiência do 
falante, de um evento ou objeto de certo tipo (49).

(49) Ami $\varnothing$ panha UMA kárga, di papelon, di simentu, 1SG.T PFV apanhar SING carga PREP papelão PREP cimento UMA fixon!

SING feijão

Eu peguei uma carga imensa, de papelão, de cimento, um monte de feijão!

Uma característica compartilhada por uma com os evidenciais é sua inefabilidade descritiva, apontada por Davis et al. (2007) e Faller (2002):

"É difícil dizer o que os evidenciais significam — difícil traduzilos, e difícil parafraseá-los com outras palavras da mesma língua."

(Davis et al., 2007:6)

"Evidenciais são notoriamente difíceis de traduzir, e traduções para o inglês tendem a sugerir que o significado do evidencial não contribui para a proposição expressa."

(Faller, 2002:3)

Apontamos, em consonância com os autores citados, a dificuldade de tradução de uma do caboverdiano para o português, pelo fato de a tradução não conseguir captar facilmente seu sentido. Temos de parafraseá-lo com algumas expressões para tentar capturar o seu significado. Considerem-se os dados (28) e (36), repetidos por conveniência:

(50) Ami $\varnothing$ peska UMA pexi!

1SG.T PFV pescar SING peixe

Eu pesquei o maior peixão!

(51) Ami $\varnothing$ konxi UMA minina bunita!

1SG.T PFV conhecer SING menina bonita

Eu conheci a menina mais linda!

Em (50) e (51) optamos por traduzir as expressões "uma pexi" e "uma minina bunita" como o maior peixão e a menina mais linda, respectivamente. Entretanto, as traduções mais próximas ao significado das expressões seriam, talvez, o maior peixe que eu já pesquei em (50) e a menina mais bonita que eu já conheci na vida em (51).

Um ponto interessante sobre a sentença (51) é que, quando o falante destaca alguma menina com uma, dificilmente outros irão discordar, ou 
seja, não haveria a possibilidade de outra pessoa discordar e não achá-la bonita - tecnicamente, a asserção torna-se incancelável. Uma veicularia também certo grau de verdade.

O professor Dr. Renato Basso, da Universidade Federal de São Carlos, em comunicação pessoal, sugeriu que uma do caboverdiano poderia, talvez, ser equivalente ao termo "puta" usado informalmente no português brasileiro para marcar ênfase, conforme dados (52) e (53). Acreditamos porém, que a singularização realizada por uma expresse mais do que este "puta" do português. Outrossim, ele não é adequado em todos os contextos em que uma pode ocorrer, como, por exemplo, nas sentenças (54) e (55):

(52) Estou com uma "puta" dor de cabeça!

(53) Pesquei um "puta" peixe!

(54) \#Conheci uma "puta" menina linda!

(55) \#Estou "puta" contente!

De volta às análises dos evidenciais, Faller (2002) utiliza-se do termo modificador ilocucionário, baseada na análise de Vanderveken (1990) que trata de certos advérbios de atos de fala que modificam o indicador principal da força ilocucionária. Essa modificação derivaria um indicador complexo, que expressa a força ilocucionária obtida da asserção ${ }^{12}$.

A autora salienta que, na maioria das línguas analisadas, os elementos que codificam evidencialidade também expressam outros conceitos - além da indicação da justificativa do falante para fazer uma afirmação - e geralmente é difícil decidir qual seria o sentido primeiro dos evidenciais. Em quechua, por exemplo, os clíticos evidenciais também apareceriam para indicar o grau de certeza do falante de que a proposição expressa é verdadeira.

Em caboverdiano, uma não poderia ser classificado como evidencial nos termos de Aikhenvald (2004), de Davis et al. (2007) ou ainda de Faller (2002). As análises sobre os evidenciais, porém, parecem fornecer uma direção de análise para uma. Partindo das noções apresentadas, analisaremos

\footnotetext{
${ }^{12} \mathrm{O}$ advérbio por favor do português, por exemplo, pode ser considerado um modificador ilocucionário, pois muda a força da proposição. Quando o advérbio é utilizado em uma sentença com força imperativa, como em "Por favor, pegue esse lápis", essa força é atenuada pelo uso do operador.
} 
na seção $7 \cdot 7$ o comportamento de uma com base nas seguintes conjecturas:

i uma estaria diretamente ligado à experiência do falante, marcando um tipo de estratégia: o de salientar determinada característica do nome;

ii a contribuição de uma seria principalmente pragmática, semelhante à contribuição dos evidenciais apontada por Davis et al. (2007), pois operaria principalmente no contexto de interação e não no sentido de um enunciado particular.

\subsection{Uma como "singularizador"}

Na seção 7.4 , verificamos que a tentativa de analisar uma como modificador de grau nos termos de Kennedy and McNally (2005) e Doetjes (2007) não seria a maneira mais adequada de explicar o funcionamento de uma no caboverdiano, já que parece haver um componente pragmático em sua ocorrência.

Outro caminho em relação à análise de uma foi a tentativa de aproximálo dos evidenciais. Entretanto, de acordo como nossas análises apresentadas na seção $7 \cdot 5$, uma também não poderia ser enquadrado nessa categoria.

Já Delgado (2009:284), em sua análise — correta, a nosso ver —, chama a atenção para algumas situações especiais em que há o "artigo indefinido" uma, como, por exemplo, "quando se quer dar ênfase a um substantivo num determinado contexto de comunicação".

Quint (2010:225) também aponta o valor enfático de uma que assinala alguma qualidade particular, como beleza, inteligência e outras.

Os dados de fala espontânea que coletamos, os resultados de alguns testes semânticos específicos, além dos debates na literatura, levam a crer que - eis a hipótese que defenderemos - a função de uma é a de tornar singular determinada qualidade, objeto ou, ainda, determinado evento. É muito importante destacar que a produção de uma, ademais, é sempre acompanhada por seu acento prosódico característico ${ }^{13}$.

As questões que serão exploradas a partir de agora concernentes ao uso de uma, a fim de fundamentar nossa hipótese, serão: (i) experiência do falante; (ii) a aparente necessidade de explicitação quando da utilização de uma; (iii) a interação com outros elementos que expressam grau; e, de modo tangencial, (iv) o papel de seu acento prosódico.

\footnotetext{
${ }^{13}$ Deve-se salientar que uma não é reconhecido na língua sem tal acento.
} 


\section{7·7.1 Experiência pessoal do falante}

De acordo com o pensamento de Faller (2002), os evidenciais em quechua não requerem que a indicação da fonte de informação seja seu sentido primeiro. Segundo a autora, os evidenciais codificam a fonte de informação, em vez de implicá-la. A autora aponta que, em algumas ocasiões, a fonte de informação mais direta possível pode não ser uma fonte de informação no sentido usual como, por exemplo, em questões de fé, que envolvem simplesmente a crença do falante.

A autora considera informação pessoal as informações sobre a vida privada dos falantes; é essa noção que tomaremos neste trabalho, na medida em que conjecturamos estar o uso de uma diretamente ligado à experiência do falante.

Em quechua, o uso do evidencial $-m i$, de acordo com as análises de Faller (2002), indica que o falante adquiriu a informação da melhor fonte dentre todas aquelas a que uma pessoa normal poderia ter acesso para o tipo de informação transmitida. De modo similar, propomos que o uso de uma indica o objeto ou evento mais singular que o falante viu ou vivenciou em dada situação. A qualidade ou especificidade do objeto ou evento, quando modificadas por uma, tornam o objeto ou evento algo exclusivo ou excepcional diante da experiência do falante.

Por exemplo, em Miranda et al. (2010: exemplos adaptados), apontamos que a sentença (56) é inadequada para expressar uma quantidade de dinheiro de todos os dias como, por exemplo, para comprar pão:

(56) \#Tene UMA dinheru riba mésa. Bu panha!

Ter SING dinheiro em.cima mesa 2 SG pegar

Todavia, caso seja uma quantia inesperadamente alta, a sentença (57) pode ser utilizada:

(57) Tene UMA dinheru riba mésa! ter SING dinheiro em.cima mesa Tem dinheiro à beça em cima da mesa!

Uma, apesar de estar ligado à experiência do falante, pode ser utilizado em informações reportadas por outros falantes, conforme exemplo (58), e ainda pode referir-se a eventos futuros, conforme (59).

(58) Nha mai $\varnothing$ fla-m ki Wânia é 1SG.POSS mãe PFV dizer-1SG.OBJ PRON.CONJ.PREP Wânia ser UMA interessadu na língua kriola! SING interessado PREP língua crioula 
Minha mãe me disse que Wânia é a pessoa mais interessada do mundo na lingua caboverdiana! ${ }^{14}$

Ami ta átxa ki $\mathrm{N}$ ta bai sta UMA

1SG.T HAB achar PRON.CONJ.PREP 1 SG HAB ir estar SING kansadu palmanhã pamodi oji $\mathrm{N} \varnothing$ trabadja txeu! cansado de.manhã porque hoje $1 \mathrm{SG}$ PFV trabalhar muito! Acho que vou estar morto de cansaço pela manhã porque trabalhei demais hoje! ${ }^{15}$

\subsubsection{Necessidade explicativa}

Em (6o), observamos a relativa inefabilidade descritiva de uma. No contexto em questão, o falante aponta para uma pessoa que rouba muito, que teria "mão leve". Porém, ao que nos parece, essa tradução não consegue capturar adequadamente o sentido de uma panhadura.

(6o) Ben un brejeru algén ten UMA panhadura, $\varnothing$ panha vir DET brejeiro alguém ter SING mão-leve, PFV apanhar sima sta! como DEM

Vem um brejeiro, alguém com uma bruta mão leve, pegou desse jeito!

Observe-se que, nesse caso, o falante singulariza o modo com que a pessoa pega (mais especificamente, trata-se de um roubo de dinheiro). Logo a seguir, em (61) o falante descreve a quantidade de coisas que essa pessoa, que roubou o dinheiro, conseguiu comprar, o que aponta para a enorme quantidade de dinheiro roubado.

(61) Panha pa fazi kunpra, kunpra dez litru grógu, kunpra apanhar PREP fazer compra, compra dez litros grogue compra saquinhu di batata inglésa, kunpra kusa, kusa, un monti saco.GRAU PREP batata inglesa compra coisa coisa DET monte kusa. Cincu litru, dez litru, kunpra un monti di kónpra. coisa cinco litros dez litros compra DET monte PREP compra. Pegou para fazer compra, comprou dez litros de grogue, comprou saquinho de batata inglesa, comprou coisas e mais coisas, um monte de coisas. Cinco litros, dez litros, comprou um monte de coisas.

\footnotetext{
${ }^{14}$ Uma outra tradução possível seria "Minha mãe disse que a Wânia é a maior interessada na língua caboverdiana."

15Uma outra tradução possível seria "Acho que vou estar maior cansado amanhã de manhã porque trabalhei demais hoje!"
} 
Um ponto interessante, quando da ocorrência de uma, é a aparente necessidade de explicação da ocorrência, conforme pode-se observar em (61), que explica o evento em (6o). Em todas as ocorrências retiradas de conversas espontâneas, houve a explicitação. Essa explicação parece, assim, ser sempre requerida pelo uso de uma, ou seja, a ocorrência de uma engatilharia alguma necessidade de explicitação do que é modificado por ele.

Observem-se os dados (62) e (63) reproduzidos na sequência. Em (63), a informante explicita o que havia nessa trouxa trazida pelo marido. Parece haver um reforço da singularidade da trouxa de roupas.

$$
\text { N'otu diânha maridu } \varnothing \text { txiga ku UMA troxa! }
$$

PREP'outro dia 1 SG.POSS marido PFV chegar com SING trouxa No outro dia, meu marido chegou com uma baita de uma trouxa (de roupa)!

(63) $\mathrm{Ku}$ dôs panu téra (...) $\mathrm{Ku}$ róbi, ku kamisa di nóti, PREP dois pano terra (...) PREP robe PREP camisa PREP noite, $\mathrm{ku}$ dôs par di sapatinhu mininu, ku dôs chapéu PREP dois par PREP sapato.GRAU menino, PREP dois chapéu di mininu, $\mathrm{ku}$ quatu kamisa di mininu, ku rôpa, PREP menino, PREP quatro camisa PREP menino, PREP roupa, $\mathrm{ku}$ tudu kusa.

PREP tudo coisa

Com dois "panos de terra" (...), com robe, com pijama, com dois pares de sapatinho de menino, com dois chapéus de menino, com quatro camisas de menino, com roupa, com todas as coisas.

Na sentença (64), coletada por meio de testes, quando se utiliza apenas a expressão "uma kábra", ressalta-se alguma particularidade dessa cabra que deve ser detalhada depois, que pode ser uma cabra que dá muito leite, conforme (64), ou uma cabra que come mais do que as outras, ou ainda a maior cabra do rebanho. De acordo com o informante, a explicação deve vir após a utilização de uma, caso contrário a informação não estaria completa.

$$
\begin{aligned}
& \text { Ami tene UMA kábra, ki ta da txeu leti! } \\
& \text { 1SG.T ter SING cabra PRON.CONJ.PREP HAB dar muito leite } \\
& \text { Eu tenho uma cabra que é demais, é uma cabra que dá muito leite! }
\end{aligned}
$$

Novamente, em (65), a característica singular da casa deve ser explicitada, não bastando apenas ressaltar a casa entre as demais; deve-se salientar também o que essa determinada casa possui, aquilo que a distingue de outras casas que a pessoa conhece. 
(65) Ami $\varnothing$ odja UMA kasa onti! Ku dôs andar, ku 1SG.T PFV olhar SING casa ontem PREP dois andar PREP piscina, ku tudu kusa! piscina PRER tudo coisa

Eu vi uma senhora casa ontem! Com dois andares, com piscina, um monte de coisas!

Em síntese, uma singulariza determinado evento, característica ou objeto. Além disso, o motivo pelo qual esse evento, característica ou objeto é tão singular deve ser explicitado pelo falante.

\section{7·7·3 Interação com os elementos que expressam grau}

Em (66), a expressão uma tankóna refere-se a um tanque enorme e que nunca fica vazio, mói-se tanto milho que o tanque não se esvazia. A singularização do tanque dá-se por uma mas, aqui, o falante ainda utilizou-se do sufixo aumentativo -óna para apontar que era realmente um tanque de milho muito grande. Ao final, o falante ainda utiliza-se da expressão "ta mui midju txeu di más", que em sentido literal significa que "mói milho muito demais", apontando para a grande quantidade de milho que é moída.

(66) Ta mui midju sacu más saku, tanki, UMA tankóna HAB moer milho saco mais saco tanque SING tanque.GRAU na kel riba ka ta seca ta mui midju txeu PREP DEM em.cima NEG HAB secar HAB moer milho muito di más! mais

Mói o milho, sacos e mais sacos, tanque, um tanque imenso, lá naquela subida, que não seca, mói milho demais!

Em Miranda et al. (2010), realizamos testes com uma para verificar a interação com elementos que expressam grau. Nas sentenças a seguir, o informante entende que uma espécie de medicamento será aplicada. Em (67) não há um comprometimento com a quantidade, nem com a qualidade do remédio a ser aplicado, no entanto, dizer (68) só seria apropriado caso o remédio em questão fosse muito eficaz ou aplicado em grande quantidade.

(67) Ami sta kaloka un ramedi na bu firida. 1SG.T estar colocar DET remédio PREP 2SG.POSS ferida. Vou passar um remédio na sua ferida.

Ami sta kaloka UMA ramedi na bu firida! 1SG.T estar colocar SING remédio PREP 2SG.POSS ferida. 
Vou passar um remédio como nenhum outro na sua ferida!

A sentença (69) enfatiza ainda mais a eficácia do remédio. A sentença (69) será adequada se o remédio aplicado for ainda mais eficaz que em (68). Interessantemente, o falante interpreta o singularizador como qualificando a eficácia do remédio em questão e não tanto sua quantidade.

Ami sta kaloka UMA bruta ramedi na bu firida! 1SG.T estar colocar SING baita remédio PREP 2SG.POSS ferida. Vou passar o melhor remédio sensacional, sem igual, na sua ferida!

Diante desses dados, somos levados a inferir que a singularização de uma pode ainda ser reforçada tanto através de um adjetivo que expressa grau (como bruta em (69)), quanto pelo uso do sufixo aumentativo (-óna adjungido ao nome que uma modifica).

A partir daí, realizamos novos testes para a verificação de aceitabilidade de uma com o sufixo -óna e com o adjetivo bruta. Apresentamos aos falantes algumas opções para que se verificasse qual seria a maneira mais adequada para expressar uma pedra extremamente grande. Em todos os questionamentos, pedimos aos informantes que oferecessem a forma correta caso nenhuma das opções fosse a mais adequada. As opções apresentadas foram as seguintes:
a. pedron;
b. uma pédra;
c. uma pedróna.

A maioria dos informantes aceitou a opção "uma pedróna" como sendo a maior pedra de todas, o que poderia reforçar a hipótese de reforço da singularização de uma por meio de outros elementos que expressam grau.

Nesse mesmo teste, procuramos igualmente verificar qual seria a opção mais adequada para o "maior sono". As opções apresentadas são as elencadas a seguir. Salientamos que esse é o mesmo contexto da sentença apresentada na subseção 7.4.2 - da parte que trata dos adjetivos que expressam grau, sentença (46) - , que fora retirada de Quint (2000).
a. bruta sónu;
b. uma bruta sónu;
c. uma sónu; 
A expressão uma sónu mostrou-se a preferida pelos informantes. Logo, o adjetivo bruta não serviu para reforçar a intensidade (do sono, no caso).

Novamente, verificamos qual forma seria a mais adequada para falar do maior bode que a pessoa já viu na vida. Foram apresentadas as opções:

a. bruta bódi;

b. uma bódi;

c. bodóna;

d. uma bodóna;

e. uma bruta bódi;

f. uma bodóna grándi.

A expressão uma bodóna grándi foi considerada agramatical pelos falantes e a expressão mais adequada para indicar o "maior bode que eu já vi na vida" é uma bódi. Concluímos, diante desses resultados, que não é sempre que a singularização de uma pode ser reforçada com o auxílio de uma expressão de grau, seja através de um adjetivo ou de um sufixo aumentativo.

Os resultados desses primeiros testes, entretanto, trouxeram à baila o questionamento de quais seriam os contextos que favorecem a interação de uma com elementos de grau, já que, em princípio, não seria possível estabelecer uma relação. Se a interação com o sufixo -óna é válida para falar de uma pedra extremamente grande, ou ainda de um tanque de milho que nunca fica vazio, ela não é válida para falar do maior bode que já se viu.

Aplicamos novos testes para elucidar os questionamentos advindos do teste anterior. Em princípio, consideramos ter o traço [+ / - animado] algum papel nessa interação.

A interação do aumentativo -óna com nomes [ - animado] foi aceito pelo informante, conforme (70), mas a ocorrência com nomes abstratos foi considerada agramatical, conforme (71) e (72), sendo preferível a utilização de uma isoladamente, como em (73) e (74).

(70) Ami $\varnothing$ pánha UMA batatóna onti! 1SG.T PFV pegar SING batata.GRAU ontem Peguei a maior batata ontem!

(71) *Ami sta ku UMA saudadóna di bu! 1SG.T estar PREP SING saudade.GRAU PREP 2 SG. 
(72) *Ami $\varnothing \quad$ pánha UMA febróna! 1SG.T pegar PFV pegar SING febre.GRAU

(73) Ami sta ku UMA saudádi di bu! 1SG.T estar PREP SING saudade PREP 2SG Estou morrendo de saudade de você!

(74) Ami $\varnothing$ pánha UMA febre! 1SG.T PFV pegar SING febre Estava com uma febre enorme!

A interação com o adjetivo bruta também causou estranhamento $(75)^{16}$.

(75) \#Ami $\varnothing$ pánha UMA bruta febre! 1SG.T PFV pegar SING baita febre \# Eu estava com uma baita febre!

Embora (77) tenha sido aceito, o exemplo (76) foi considerado o mais adequado entre as opções apresentadas para expressar que alguém passa por um problema extremamente grande. A sentença (78) causou estranhamento ao informante, que a considerou uma expressão pouco utilizada.

(76) El sta $\mathrm{ku}$ UMA prublema! ${ }_{3}$ SG estar PREP SING problema Ele está com o maior problema!

(77) El sta $\mathrm{ku}$ un prublema grándi. 3SG estar PREP DET problema grande Ele está com um problema grande.

(78) \#El sta $\mathrm{ku}$ un problemóna. 3SG estar PREP DET problema.GRAU Ele está com um problemão.

Ao que parece, uma seria exclusivo para singularizar determinada característica. Em relação à interação com elementos que expressam grau, o traço [+ / - animado] parece realmente ter alguma relevância. Quando se trata de nomes com o traço [-animado], a coocorrência de uma com o sufixo -óna parece aceitável. Por outro lado, quando se trata de nomes abstratos

\footnotetext{
${ }^{16}$ Ao que parece, esse adjetivo não seria tão utilizado na variedade de Santiago, com uma sendo escolhido como a melhor opção para singularizar determinada característica; isso poderia explicar a escolha de "uma sónu" para referir-se a um sono exageradamente grande, em vez de "uma bruta sónu". Acreditamos, porém, que a variação dialetal pode não ser a explicação mais adequada para esse estranhamento e reconhecemos a necessidade de maior aprofundamento nessa questão.
} 
ou com o traço [+ animado], essa coocorrência não seria permitida.

Outro ponto relevante seria a impossibilidade de uma combinar-se com mais de um elemento que expressa grau, o que pode ser observado pela agramaticalidade atribuída pelos informantes à expressão "uma bodóna grándi". Todos os outros exemplos foram considerados gramaticais, com uma ocorrendo ou somente com o adjetivo de grau ou com o sufixo aumentativo. Não seria possível, no entanto, a ocorrência de uma com o sufixo aumentativo somado ainda a um adjetivo de grau.

\section{Ocorrência com eventos valorizados negativamente}

Outra questão verificada nos testes foi a aparente exclusividade de uma em eventos valorizados positivamente. Contudo, a ocorrência de uma não é restrita a esses contextos, conforme (79):

(79) Ami sta UMA tristi oji! 1SG.T estar SING triste hoje

Estou na maior tristeza hoje!

\subsection{Considerações do capítulo}

Diante do exposto no presente capítulo, uma não poderia ser classificado como evidencial, tampouco como advérbio de grau ou ainda como artigo indefinido.

Aqui, propomos interpretar uma como singularizador, já que, pelo que apontamos até então, sua função é a de tornar singular determinada qualidade, um objeto ou ainda determinado evento.

Essa característica seria particular a uma, já que parece não existir outro elemento em caboverdiano que tenha a função de singularizar determinado objeto, qualidade ou evento. Logo, uma não participa do paradigma dos modificadores de grau, pois as expressões de grau não codificam a mesma informação veiculada por ele, embora possam reforçá-la, sendo uma exclusivo para tal função.

O papel do acento fonológico parece ser o de reforçar a singularização, pois sempre ocorre com tal acento e, conforme apontamos na seção $7 \cdot 2$, não é reconhecido na língua sem ele.

De acordo com a hipótese levantada, a contribuição de uma seria principalmente pragmática, dado que não veicula toda a informação relevante sozinho, havendo necessidade de explicitação posterior. Ele destaca o nome que modifica, mas o que torna singular o objeto deve ser explicitado para que a informação seja completa. Ou seja, uma marcaria a estratégia do 
falante dentro do contexto de interação de ressaltar o nome, engatilhando a "necessidade" de completar a informação introduzida por ele.

Em síntese, uma pertence a uma classe distinta da classe dos artigos indefinidos e também dos modificadores de grau. Este fato também explica o porquê de o analisarmos em capítulo distinto daquele que trata dos determinantes e demonstrativos do caboverdiano. 


\section{CAPÍTULO 8}

\section{Considerações Finais}

Este trabalho analisou algumas características semânticas do sintagma nominal do caboverdiano, explorando diferentes estratégias de interpretação dos nomes.

No capítulo 4, apresentamos diferentes perspectivas teóricas sobre a formação das línguas crioulas, realizando um panorama histórico sobre as diferentes abordagens. Salientamos, por fim, a visão adotada neste trabalho que está em consonância com a dos autores Mufwene (2001), (2008) e Chaudenson (2001), no sentido de que aquilo que torna possível a classificação de uma língua como crioula são as condições sócio-históricas de seu surgimento e, ainda, que essas condições fazem parte de um processo sociolinguístico peculiar ao desenvolvimento das sociedades que surgiram na colonização europeia do século XVI. Por isso, optamos por nos referir à língua como caboverdiano e não como crioulo de Cabo Verde.

No capítulo 5, apresentamos as características gerais do sintagma nominal do caboverdiano. Observamos que nessa língua os nomes, em geral, não são acompanhados de determinantes e que a língua possui diferentes estratégias para a interpretação dos nomes enquanto definidos, indefinidos ou genéricos. Essas estratégias podem ser sintáticas, semânticas ou pragmáticas. Defendemos ainda que as diferentes estratégias de interpretação dos nomes não estão necessariamente atreladas às diferentes leituras das sentenças e que esses são processos distintos.

Não obstante o fato, a língua possui um determinante indefinido. Sua utilização, porém, não pode ser considerada frequente. A função de un na língua estaria associada à introdução de novos referentes, enquanto 
a retomada seria realizada sem a presença de qualquer determinante ou, ainda, em casos esporádicos, através do demonstrativo kel.

No capítulo 6 apresentamos que, assim como um conjunto de línguas que não possuem artigo definido, o caboverdiano utiliza-se do demonstrativo para veicular definitude. Esse uso, porém, não é considerado frequente. Através das análises, evidenciamos que kel comporta-se exclusivamente como um demonstrativo, mesmo em situações (por vezes advogadas por outros autores) em que ele se comportaria como um determinante definido.

O capítulo 7 foi dedicado à análise de uma. Verificamos que uma ocorre de modo frequente em caboverdiano e ainda, possui estratégias específicas de ocorrência. A função de uma seria a de salientar um objeto, qualidade ou evento, tornando-os como nenhum outro do mesmo tipo. Daí a proposta de chamá-lo de singularizador, pois torna singular, no sentido de ser como nenhum outro, este objeto, qualidade ou evento.

Diante do que fora apresentado nesta dissertação, salientamos novamente a diferença entre o português e o caboverdiano. Um exemplo disso é a contribuição ilocucionária de uma presente na sintaxe aberta do caboverdiano. Desta feita e conforme apontamos no capítulo 4, o caboverdiano deve ser estudado com base nos fatos da própria língua, evitando comparações diretas com o português europeu (ou com o português brasileiro), devido a uma alegada ancestralidade, ou ainda devido a uma "ruptura" em relação ao português europeu.

Apontamos ainda que poderia ser relevante para o estudo do caboverdiano uma comparação com algumas línguas africanas (que possivelmente participaram da formação da língua), no sentido de verificar, por exemplo, se há entre elas casos de marcação ilocucionária na sintaxe aberta, tal como verificamos em caboverdiano. Esse fato poderia, também, ajudar a elucidar as línguas que tiveram participação na formação do caboverdiano.

Partindo da perspectiva teórica do contato de línguas em que diferentes línguas contribuem com suas respectivas características ou traços para a mudança, e que o novo código linguístico formado "escolhe" características das diferentes línguas, ou ainda características convergentes dessas línguas, esse poderia ser um aspecto interessante a se investigar nas línguas africanas historicamente vinculadas à formação do caboverdiano. 


\section{Referências Bibliográficas}

Abney, S. P. (1987). The English noun phrase in its sentential aspect. Ph. D. thesis, MIT, Cambrigde, Mass.

Aikhenvald, A. Y. (2004). Evidentality. New York: Oxford University Press Inc.

Alexandre, N. and N. V. Soares (2004). O domínio nominal em crioulo de cabo verde: o puzzle dos bare nouns. XX Encontro Nacional da Associação Portuguesa de Linguística APL, 337-350.

Alexiadou, A., L. Haegeman, and M. Stavrou (2007). Noun Phrase in the Generative Pespective. Berlim / New York: Mouton de Gruyter.

Anderson, L. B. (1986). Evidentiality: The Linguistic Coding of Epistemology, Chapter Evidentials, paths of change and mental maps: Typologically regular asymmetries, pp. 273-312. Norwood: Ablex Publishing Corporation.

Arends, J. (1993). Atlantic meets Pacific, Chapter Towards a gradualist model of creolization, pp. 371-38o. Amsterdam: John Benjamins.

Arends, J. (1994). Pidgins and Creoles: an introduction, Chapter The sociohistorical background of creoles, pp. 15-24. Amsterdam/ Philadelphia: John Benjamins Publishing Company.

Arends, J. and A. Bruyn (1994). Pidgins and Creoles: an introduction, Chapter Gradualist and developmental hypotheses, pp. 111-120. Amsterdam/ Philadelphia: John Benjamins Publishing Company. 
Arends, J., S. Kouwernberg, and N. Smith (1994). Pidgins and Creoles: an introduction, Chapter Theories focusing on the non-European input, pp. 99-109. Amsterdam/ Philadelphia: John Benjamins Publishing Company.

Baptista, M. (1997). The Morpho-Syntax of Nominal and Verbal Categories in Capeverdean Creole. Ph. D. thesis, Harvard University.

Baptista, M. (2002). The syntax of Cape Verdean Creole - the Sotavento Varieties, Volume 54. Amsterdam / Philadelphia: John Benjamins.

Baptista, M. (2007). Noun Phrases in Creole Lauguage: a multi-faceted approach, Chapter On the syntax and semantics of DP in Cape Verdean Creole, pp. 61-105. Amsterdam/ Philadelphia: John Benjamins Publishing Company.

Bickel, B., B. Comrie, and M. Haspelmath. The Leipzig Glossing Rules: Conventions for interlinear morpheme-by-morpheme glosses. Max Plack Institute. Acessado em 27/02/2013.

Bickerton, D. (1981). Roots of Language. Ann Arbor: Karoma.

Bickerton, D. (1991). On the supposed 'gradualness' of creole development. Journal of Pidgin and Creole Languages 6, 25-58.

Brásio, P. A. (1962). Descobrimento, povoamento, evangelização do arquipélago de cabo verde. Studia $n$. 1o 1, 49-97.

Brüser, M., A. d. R. Santos, E. Dengler, and A. Blum (2001). Dicionário do Crioulo de Santiago (Cabo Verde): com equivalentes de tradução em alemão e português. Tübingen: Gunter Narr Verlag Tübingen.

C. Lyons, C. (1999). Definiteness. Cambridge: Cambridge University Press.

Cançado, M. (2005). Manual de semântica: noções básicas e exercícios. Belo Horizonte: Editora UFMG.

Carden, G. and W. Steward (1988). Binding theory, bioprogram, and creolization. Journal of Pidgin and Creole Languages 3(1), 1-68.

Carlson, G. (1977). A unified analyses of the english bare plural. Linguistics and Philosophy 1, 413-456.

Carreira, A. (1983). Cabo Verde: Formação e extinção de uma sociedade escravocrata (1460-1878) (Terceira - Ano: 200o ed.). Praia: Estudos e Ensaios - Instituto de Promoção Cultural. 
Chaudenson, R. (1974). Le lexique du parler créole de la Réunion. Paris: Champion.

Chaudenson, R. (1977). Pidgin and creole linguistics, Chapter Toward the reconstruction of social matrix of creole languages, pp. 259-276. Bloomington: Indiana University Press.

Chaudenson, R. (2001). Creolization of language and culture. London and New York: Routledge. Revisado em colaboração com Salikoko S. Mufwene.

Chierchia, G. and S. McConnell-Ginet (1996). Meaning and Grammar: An Introduction to Semantics. Cambridge, MA: MIT Press.

Christophersen, P. (1939). The Articles - A study of their Theory and Use in English. Copenhagen: Munksgaard.

Coelho, F. A. (1881). Os dialectos românicos ou neolatinos na africa, asia e américa. Boletim da Sociedade de Geographia de Lisboa 2, 129-196.

Davis, C., C. Potts, and M. Speas (2007). The pragmatic values of evidential

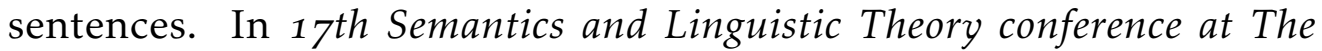
University of Connecticut., pp. 71-88.

Delgado, C. A. (2009). Crioulos de Base Lexical Portuguesa como factores de identidades em África: O caso de Cabo Verde (subsídios para uma abordagem metodológica). Praia: Instituto da Biblioteca Nacional e do Livro.

den Besten, H., P. Muysken, and N. Smith (1994). Pidgins and Creoles: an introduction, Chapter Theories focusing on the European input, pp. 87-98. Amsterdam/ Philadelphia: John Benjamins Publishing Company.

Dillard, J. L. (1970). Principles in the history of american english: Paradox, virginity, and cafeteria. Florida Foreign Language Reporter 8, 32-33.

Dimmendaal, G. (2001). Linguistic Fieldwork, Chapter Places and people: field sites and informants, pp. 55-75. Cambridge: Cambridge University Press.

Doetjes, J. (2007). Adverbs and quantification: degree versus frequency. Lingua 117, 675-720.

Dryer, M. S. (2011a). The World Atlas of Language Structures Online., Chapter Chapter 38: Indefinite Articles, pp. 1-1. http://wals.info/: Munich: Max Planck Digital Library. Acessado em 27/02/2013. 
Dryer, M. S. (2011b). The World Atlas of Language Structures Online, Chapter Chapter 37: Definite Articles, pp. 1-1. http://wals.info/: Munich: Max Planck Digital Library. acessado em 27/02/2013.

Faller, M. T. (2002). Semantics and pragmatics of evidentials in Cuzco Quechua. $\mathrm{Ph}$. D. thesis, Stanford University.

Giusti, G. (1993). La sintassi dei determinanti. Padova: UniPress.

Giusti, G. (1997). The New Comparative Syntax, Chapter The categorial status of determiners, pp. 95-124. London: Longman.

Giusti, G. (2002). Functional structure in DP and IP: The cartography of syntatic structure., Volume 1 , Chapter The functional structure of noun phrases. A bare phrase structure approach., pp. 157-171. Oxford: Oxford University Press.

Hawkins, J. (1978). Definiteness and Indefiniteness. London: Croom Helm.

Heim, I. R. (1982). The Semantics of Definite and Indefinite Noun Phrases. Ph. D. thesis, University of Massachusetts.

Holm, J. (2004). Languages in Contact: the partial restructuring of vernaculars. Cambridge: Cambridge University Press.

Huttar, G. (1975). Sources of ndjuka african vocabulary. New West Indian Guide 1/2, 45-71.

Ilari, R. and J. W. Geraldi (1987). Semântica. São Paulo: Ática.

Inverno, L. and D. Swolkien (2003). O artigo definido zero em dois contextos específicos no português do brasil e no crioulo de cabo verde. Biblios 1(I), 179-192.

Jagger, P. J. (1985). Factors governing the morphological coding of referents in Hausa narrative discourse. Ph. D. thesis, UCLA.

Kennedy, C. and L. McNally (2005). Scale structure, degree modification, and the semantics of gradable predicates. Language $812,345-381$.

Kihm, A. (1994). Kriyol Syntax: The portuguese-based creole language of Guinea-Bissau. Amsterdam/Philadelphia: John Benjamins Publishing Company.

Labov, W. (1990). The intersection of sex and social class in the course of linguistic change. Language Variation and Change 2, 205-254. 
Lang, J. (1994). o interesse da linguística pelo crioulo de cabo verde. Papia: Revista de Crioulos de Base Ibérica 3, 90-107.

Lasersohn, P. (1999). Pragmatic halos. Language 75 3, $522-551$.

Loebel, E. (1989). Syntatic phrase structure phenomena, Chapter Q as functional category, pp. 133-158. Amsterdam/ Philadelphia: John Benjamins.

Longobardi, G. (1994). Reference and proper names: A theory of nmovement in syntax and logical form. Linguistic Inquiry 25 (4), 609-665.

Longobardi, G. (1996). The syntax of N-raising: a minimalist theory. Utrecht: OTS Working Papers.

Lucchesi, D. (1994). Os artigos nos crioulos de cabo verde e são tomé: princípios gerais e fatores específicos. Papia: Revista de Crioulos de Base Ibérica 3(1), 61-83.

Matthewson, L. (2004). On the methodology of semantic fieldwork. International Journal of American Linguistics 70, 369-415.

McWhorter, J. (1992). Substratal influence in saramaccan serial verb construction. Journal of Pidgin and Creole Languages 4, 1.

McWhorter, J. (2005). Defining Creole. New York: Oxford University Press.

Miranda, W. (2013). O sintagma nominal do caboverdiano: uma investigação semântica. Master's thesis, Departamento de Linguística. Faculdade de Filosofia, Letras e Ciências Humanas da Universidade de São Paulo.

Miranda, W., M. S. Duarte de Oliveira, and A. P. Quadros Gomes (2010). Sobre a (in)existência de artigo em caboverdiano. Língua portuguesa: ultrapassar fronteiras, juntar culturas 1, 1-20. Évora: Portugal.

Mufwene, S. (2001). The Ecology of Language Evolution. Cambridge: Cambridge University Press.

Mufwene, S. (2008). Language Evolution: Contact, Competition and Change. New York: Continuum International Publishing Group.

Mühlhäsler, P. (1986). Pidgin and Creole Linguistics. Oxford: Basil Blackwell.

Müller, A. (2004). Sentido e Significação, Chapter Tópico, Foco e Nominais nus no PB, pp. 77-95. São Paulo: Contexto. 
Müller, A. L. (2003). Semântica Formal, Chapter A expressão da genericidade nas línguas naturais, pp. 154-172. São Paulo: Editora Contexto.

Muysken, P. and N. Smith (1994). Pidgins and Creoles: an introduction, Chapter The study of pidgin and creole languages, pp. 3-14. Amsterdam/ Philadelphia: John Benjamins Publishing Company.

Muysken, P. and T. Veenstra (1994). Pidgins and Creoles: an introduction, Chapter Universalist approaches, pp. 121-134. Amsterdam/ Philadelphia: John Benjamins Publishing Company.

Oliveira, M. S. D. and W. Miranda (2011, Novembro). O np estendido em jurussaca: Uma breve análise do sintagma nominal. I Seminário Internacional do GELIC (Grupo de Estudos em Línguas em Contato).

Pereira, E. A. C. (2006). Os caminhos da revolta em cabo verde e a cultura de resistência: as revoltas dos engenhos (1822) e de achada falcão (1841). Master's thesis, Departamento de História da Faculdade de Filosofia, Letras e Ciências Humanas da Universidade de São Paulo.

Petter, M. M. T. (2008). Variedades Linguísticas em Contato: Português Angolano, Português Brasileiro e Português Moçambicano. Tese de livredocência, Universidade de São Paulo.

Pratas, F. (2002). O sistema pronominal do caboverdiano (variante de santiago): Questões de gramática. Master's thesis, Faculdade de Ciências Sociais e Humanas da Universidade Nova de Lisboa.

Quadros Gomes, A. P. (2009). O efeito grau máximo sobre os domínios: como todo modifica a relação argumento e predicado. Ph. D. thesis, Departamento de Linguística. Faculdade de Filosofia, Letras e Ciências Humanas da Universidade de São Paulo.

Quint, N. (2000). Grammaire de la langue Cap-Verdienne. Paris: L'Harmattan.

Quint, N. (2009). O Caboverdiano de bolso. France: Assimil.

Quint, N. (2010). Vamos Falar Caboverdiano: Lingua e Cultura. Paris: L'Harmattan.

Roberts, C. (2002). Information Sharing: Reference and Presupposition in Language Generation and Interpretation, Chapter Demonstratives as Definite, pp. 89-196. Stanford: CSLI Press. 
Rodrigues, U. R. d. S. (2007). Fonologia do Caboverdiano: das Variedades Insulares à Identidade Nacional. Ph. D. thesis, Universidade de Brasília.

Santos, M. E. M., M. M. F. Torrão, and M. J. Soares (Eds.) (2007). História Concisa de Cabo Verde. Praia: Instituto da Investigação e do Património Culturais; Lisboa: Instituto de Investigação Científica Tropical.

Schuchardt, H. (1882). Kreolische studien i: Ueber das negerportugiesische von s. thomé (westafrika). Sitzungsberichte der kaiserlichen Akademie der Wissenschaften zu Wien 101 2, 889-917.

Searle, John, R. and D. Vanderveken (1985). Foundations of Illocutionary Logic. Cambridge: Cambridge University Press.

Stowell, T. A. (1989). Alternative conceptions of phrase structure, Chapter Subjects, specifiers, and X-bar theory, pp. 232-262. Chicago: University of Chicago Press.

Stowell, T. A. (1991). Views on Phrase Structure, Chapter Determiners in NP and DP, pp. 37-56. Kluwer: Dordrecht.

Szabolcsi, A. (1994). Syntax and Semantics 27, Chapter The noun phrase. The syntatic structure of Hungarian., pp. 179-275. New York: Academic Press.

Taylor, D. (1961). Comparative Studies in Society and History, Volume 3, Chapter New languages for old in the West Indies, pp. 277-288. Cambridge: Cambridge University Press.

Thomason, S. G. and T. Kaufman (1988). Language Contact, Creolization, and Genetic Linguistics. Califórnia: University of California Press.

Thompson, R. W. (1961). A note on some possible affinities between the creole dialects of the old world and those of the new. Le page: Creole Language Studies 2, 107-113.

Veiga, M. (2002). O Caboverdiano em 45 lições. Praia: INIC.

Veiga, M. (2004). A Construção do Bilinguismo. Praia: Instituto da Biblioteca Nacional e do Livro.

Veiga, M. (2012). Dicionário Caboverdiano-Português. Praia: Instituto da Biblioteca Nacional e do Livro. 
Volto ao Brasil e quero contar da minha viagem a Cabo Verde, dos lugares que conheci e, principalmente do que eu mais gostei.

(1) a. Kel kau foi ki N gosta más.

b. N kré txeu odja kel otu bes.

c. N atxa ki bo ta ba gosta txeu di kel kau.

Estou planejando minha próxima viagem e quero que meu marido me acompanhe:

(2) a. Nu bai ta fazi kel viáxi.

b. Kel viáxi ta ba ser mutu bon.

c. Bo kré ta bai na kel viáxi?

Se eu quero falar de uma pessoa, mas não sei quem é a pessoa. A única informação que tenho é que ela trabalha no mercado:

(3) Kel ki trabadja na merkadu.

Se eu quero falar de alguém que beijou Maria na festa, não sei quem beijou, mas sei que agarrou Maria, deu um beijo e saiu correndo:

(4) Kel ki beja Maria é dodu.

Em um contexto semelhante, mas agora sei que foi João quem beijou:

(5) a. Djon, kel ki beja Maria.

b. Djon, kel li ki beja Maria.

c. Djon, kel la ki beja Maria. 
Qual seria a diferença entre as três acima?

Para falar de alguém que chegou na cidade. Ainda não sei quem é, mas sei que chegou ontem:
a. Kel ki txiga onti!
b. Kal la ki txiga onti!
c. Kal li ki txiga onti!

Em um contexto em que alguns meninos estão jogando bola e um deles fica bravo, pega a bola, sai correndo e vai embora:

(7) a. Mininu pega bola.

b. Kel mininu pega bola.

c. Kel mininu li pega bola.

d. Kel mininu la pega bola.

Se quero pegar uma maçã que está numa cesta e eu peço para Maria, por exemplo, daí ela responde:

(8) a. Bu pega kel ki bu ta atxa más bunitu (sábi)

b. Bu pega kel li ki bu ta atxa más bunitu (sábi)

Se eu vi um menino ontem, não sei o nome dele, tampouco a pessoa com quem falo:

(9) a. Kel mininu ki N odja onti

b. Kel mininu la ki $\mathrm{N}$ odja onti

Se eu deixei alguma coisa em cima da mesa, mas ela não está mais lá e eu estou procurando:

(10) a. Undi sta kel kusa ki staba riba mesa?

b. Undi sta kel kusa li ki staba riba mesa?

c. Undi sta kel kusa la ki staba riba mesa?

Sobre a aceitabilidade das sentenças abaixo:

(11) Kel ki ta krê tudu ka ta ten nada.

(12) Tudu kel ki ta trabadja ta meresi un bon dinheru. 
João está jogando bola e machuca o joelho, mas não percebe que está sangrando. Você quer avisá-lo:

(13) a. Odja Djon, sata sai sangi di bu djuedju.

b. Odja Djon, sata sai un sangi di bu djuedju.

c. Odja Djon, sata sai dôs sangi di bu djuedju.

d. Odja Djon, sata sai un bon bukadu sangi di bu djuedju.

O João entra e você vai passar um remédio em seu machucado:

(14) a. N sta kaloka ramedi na bu firida.

b. N sta kaloka un ramedi na bu firida.

c. N sta kaloka uma ramedi na bu firida.

d. N sta kaloka uma bruta ramedi na bu firida.

João vai a uma festa e conhece uma garota. Ele a considera a garota mais bonita que já conheceu:

(15) a. N konxi uma minina na es fésta.

b. Tinha uma minina na kel fésta.

Se eu, por exemplo, fui ao Sucupira e comprei muitos vestidos.

(16) N kónpra uma bistidu!

Caso eu encontre uma quantidade enorme de dinheiro:

(17) N kóntra uma dinheru! 
Caso alguém esteja passando por um problema muito grande, de difícil solução:

(18) a. El ten uma prublema!

b. El ten un prublema grándi!

c. El ten un problemóna!

Caso alguém tenha o pé muito grande:

(19) E ten uma pé!

Quanto à distância:

(20) a. É uma lonji!

b. É uma kaminhu!

c. É uma pértu!

Se chove muito forte, mas dura apenas cinco minutos, ou seja, é uma chuva rápida:

(21) Txobe uma txuba onti! 